\title{
第5次酸性雨全国調査報告書（平成27年度）
}

\section{全国環境研協議会 酸性雨広域大気污染調査研究部会}

堀江洋佑, 岩崎綾, 友寄喜貴, 藤田大介, 河野明大, 西山亨, 久恒邦裕, 木戸瑞佳, 濱村研吾, 山添良太, 松本利恵, 多田敬子, 山口高志, 横山新紀, 家合浩明, 甲斐勇, 濱野晃, 吉田芙美香

\section{はじめに}

全国環境研協議会による酸性雨全国調査は1991年度か らの第1次調查に始まり, 現在 2016 年度からの第6次調査 を実施しています。

今回, 当報告書では, 第5次調査の最終年度である 2015 年度の調查結果を報告するとともに, 第5次調查7年間の 結果を取りまとめました。

この間の調査を振り返ると，第1次調査（1991～1993 年度) では, ろ過式採取法 (バルク) による調査を行い, 全国的な降水の酸性化を明らかにしました。

第2次調查（1995１997年度）では，夏季および冬季に 日単位調查や流跡線解析を行いました。この結果, 冬季 に日本海側で沈着量が多く, 硫酸イオンを多く含む気塊 が中国や朝鮮半島を通過していたこと，カルシウムイオ ンを多く含む気塊は，モンゴルや中国北東部を起源とす る場合が多かったことなどを明らかにし, 酸性物質の移 流の可能性が示唆されました。

第3次調查（1999～2001年度）では, 湿性沈着（降水時 開放型捕集装置法）に加えて, 乾性沈着を把握するため に，4段ろ紙法（フィルターパック法）によるガス・エ アロゾル調査を実施しました。この結果, 都市部におけ る酸性雨の状況, 硫黄酸化物や窒素酸化物の地域特性, さらに大気中のガス成分, 粒子状成分について全国的な 濃度分布とその季節変化を明らかにするとともに, 乾性 沈着量の推定を行いました。

第4次調查（2003～2008年度）では，乾性沈着量の空間 分布について, より正確に把握するために, フィルター パック法では測定できない窒素酸化物やオゾン濃度等が 測定可能であるパッシブ法を導入しました。また, 乾性 沈着速度を算出するプログラムを共同開発し, 乾性沈着 量の評価を実施しました。

2009年度には部会名称を「酸性雨調査研究部会」から 「酸性雨広域大気污染調查研究部会」と改め, 窒素成分 のより高度な沈着量の把握などを含めた第5次調查を開 始し，2015年度までの7年間実施しました。2016年度から は第6次調查を開始し,フィルターパック法による乾性沈
着調査において, 従来の4段ろ紙法から5段もしくは6段ろ 紙法一の移行を推奨し, さらに高精度かつ広域的な全国 調查を実施しています。

今回, この成果が, 各地域でのデータ解析評価の一助 となれば幸いです。また，調査結果の解析では広域大気 污染についても検討を行っており, 今後も継続したデー 夕収集および解析により, 東アジア酸性雨モニタリング ネットワークの充実に貢献したいと考えています。

このように，本部会の取組は，日本における酸性雨調 查を面的および項目的に補完しており，環境省および国 立研究開発法人国立環境研究所と連携して, 全国的な情 報・知見の集積を行う上で，地方研究機関の役割・貢献 が極めて大きいことを示していると思われます。加えて， 最近では $\mathrm{PM}_{2.5}$ による大気污染等の問題により, 環境行政 に対する国民の関心が非常に高くなっております。この ような中で，われわれ地方環境研究機関が中心となって 独自の調査研究を行っていくことは, 環境行政の推進に 必要不可欠であり, 今後も継続していくことが重要であ ると思われます。

最後になりましたが, 行財政状況の大変厳しい中, 本 部会の活動にご参加いただきました全国環境研協議会会 員機関と調查担当の皆様, 本調查の企画・解析等にご尽 力されました各委員, 有益なご助言・ご指導をいただき ました有識者の皆様, 本調查に対し多大なご協力・ご支 援をいただきました環境省, 国立環境研究所, (一財) 日 本環境衛生センターノアジア大気污染研究センター, な らびに，その他の多くの皆様に，この場をお借りしまし て, 深くお礼を申し上げます。今後も引き続き, 当部会 の活動に皆様のご支援・ご協力を賜りますようお願い申 し上げます。

\section{平成29年 7 月}

\section{全国環境研協議会}

酸性雨広域大気污染調查研究部会

部会長 四宮 博人

(愛媛県立衛生環境研究所 所長) 


\section{1. 調查目的}

全国環境研協議会 (以下, 全環研) は, 表1.1.1に示すよ うに1991年度から全国調查を行ってきた。その結果，全 国の湿性および乾性沈着について, 地域特性, 季節変化, 火山・大陸の発生源の影響, 乾性沈着速度評価などの多 くの知見を得てきた。第1次から第3次調查までは3カ年の 調查の後, 1 年間の準備期間を経て次の調查を行ってきた が, 2003〜2005年度の予定で開始した第4次調查では急速 に増大し始めた中国の $\mathrm{SO}_{2}$ およびNO排出量の影響などが 㲘念されたことから, 追加調查として3カ年, 2008年度ま で計6年間の調查を実施した。

2009年度〜2015年度は，これまでの調查に加え窒素成 分のより高度な沈着量の把握やバックグラウンドオゾン 濃度の把握などを含めた第5次調查を実施した。本調査の 目的は, 日本全域における酸性沈着による污染実態を把 握することであり, (1)国際標準の方法である降水時開放 型捕集装置 (ウエットオンリーサンプラー)による湿性沈 着の把握，(2)自動測定機，国際的モニタリングネットワ ークでも用いられているフィルターパック法およびパッ シブ法による乾性沈着成分 (ガス/エアロゾル)濃度の把 握, (3)インファレンシャル法による乾性沈着速度算出お よび乾性沈着量評価, 以上の3つが主なテーマである。第 5次調查の特徵としては, (1)第4次調查から準備年をおか ずに継続して実施していること, (2)パッシブ法を小川式 (0式)に統一寸ることにより, 広域の解析・とりまとめを 目指すこと, (3)アンモニア・アンモニウムイオンの成分 ごとの評価を目指すことなどが挙げられる。

なお, 第1～5次調查結果 (2014年度まで) は国立環境研 究所地球環境研究センターにおける地球環境データベー ス (http://db. cger. nies. go. jp/dataset/acidrain/ja/ index. html)にて公開されている。

\section{2. 調查内容}

\section{1 調查概要}

2015年度の調査参加機関は表2.1.1亿示寸49機関であ り, 湿性沈着調查地点は68地点, 乾性沈着調查地点は 44 地点 (フィルターパック法: 31 地点, パッシブ法: 26 地点) である。なお,一部には, 他の学術機関との共同研究1, 2), 国設局との共用データも含まれている。なお，環境省の データとは降水量の算出方法(気象データを用いる場合 と貯水量を用いる場合)などデータの算出法が一部異な るため, 数值が一致しない場合があることに注意が必要 である。

2015年度の調查期間は原則として2015年4月 6日～2016 年4月 4 日であり, 季節および月の区切りは表2.1.2に示す とおりである。

本調査および報告書の作成は全環研・酸性雨広域大気 污染調查研究部会が主導して行われた。2015～2016年度 の部会組織および報告書の担当を表2.1.3に示す。

\section{2 調查方法}

\section{2.1 湿性沈着}

調查地点は1地点の場合は原則として都市域で実施し， 複数地点の場合は都市域および都市域から $20 \sim 30 \mathrm{~km}$ 離 れた地点または(および)地方に特有の地点で実施して いる。

調査は, 通年調査とし，1週間単位での採取を原則と するが，2週間あるいはそれ以上での採取も可とし，そ の場合, 冷蔵庫の設置等による試料の変質防止対策を推 奨している。試料採取は原則月曜日に行った。なお，解 析に用いるデータは表2.1.2 に示寸月単位である。

降水の捕集装置は降水時開放型であり, 降雪地域にお いては, 移動式の蓋の形状変更や涷結防止用ヒーターの 装備などの対策をとることが望ましいが，ヒーターの使

\section{表1.1.1 全国環境研協議会・酸性雨広域大気污染調査研究部会による酸性雨全国調査の主な調査内容}

\begin{tabular}{|c|c|c|c|c|c|c|c|c|c|c|}
\hline & 第1次酸性雨全国調査 & 第2次酸性雨全国調查 & \multicolumn{2}{|c|}{ 第3次酸性雨全国調查 } & \multicolumn{3}{|c|}{ 第4次酸性雨全国調查 } & \multicolumn{3}{|c|}{ 第5次酸性雨全国調查 } \\
\hline 詿查刘象 & 降水成分 & 降水成分 & 湿性沈着 & 榦性沈着 & 湿性沈着 & & 生沈着 & 湿性沈着 & & 沈着 \\
\hline $\begin{array}{l}\text { 謂查 } \\
\text { 地点数 } \\
\end{array}$ & $\begin{array}{l}\text { 1991年度: }: 158 \text { 地点 } \\
\text { 年992年度度地地点 } \\
\text { 1993年度: } 140 \text { 地点 }\end{array}$ & $\begin{array}{l}\text { 1995年度: } 52 \text { 地点 } \\
\text { 1996年度: } \\
\text { 1997年度 }: 53 \text { 地点 }\end{array}$ & $\begin{array}{l}1999 \text { 年度: } 447 \text { 地点 } \\
2000 \text { 年度: } 48 \text { 地点 } \\
2001 \text { 年度 }: 52 \text { 地点 }\end{array}$ & $\begin{array}{l}\text { 1999年度: } 25 \text { 地点 } \\
\text { 2000年度: } \\
2001 \text { 年度 } 27 \text { 地点 }\end{array}$ & $\begin{array}{l}\text { 2003年度: } 61 \text { 地点 } \\
\text { 2004年度: } 16 \text { 地点 } \\
\text { 2005年度: } 62 \text { 地点 } \\
\text { 2006 年度: } \\
\text { 2007地点 } \\
\text { 2008年度: }: 1 \text { 地点 }\end{array}$ & 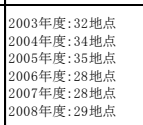 & $\begin{array}{l}\text { 2003年度: }: 59 \text { 地点 } \\
\text { 2004年度: } \\
2005 \text { 地点 } \\
\text { 2006年度: }: 59 \text { 地点 } \\
\text { 2007年度: }: 39 \text { 地点 } \\
\text { 2008年度: }: 37 \text { 地点 }\end{array}$ & $\begin{array}{l}\text { 2009年度: }: 2 \text { 地点 } \\
\text { 2010年度: } 67 \text { 地点 } \\
\text { 2011 } \\
\text { 2012年度: } 6 \text { 地地点 } \\
\text { 2013年度: }: 6 \text { 地点 } \\
\text { 2014年度: } \\
\text { 2015地点 }\end{array}$ & 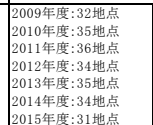 & $\begin{array}{l}2009 \text { 年度: }: 42 \text { 地点 } \\
\text { 2010年度: } 41 \text { 地点 } \\
\text { 2011年度 }: 8 \text { 地点 } \\
2012 \text { 年度 }: 36 \text { 地点 } \\
\text { 2013年度: } \\
\text { 2014地点 } \\
2015 \text { 年度 }: 28 \text { 地点 }\end{array}$ \\
\hline 調盉手法 & 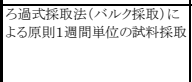 & 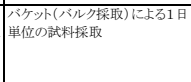 & 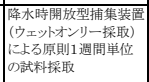 & 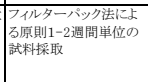 & 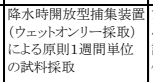 & 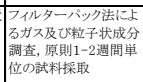 & 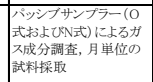 & 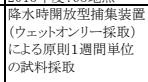 & 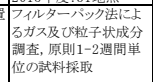 & 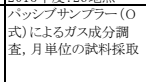 \\
\hline 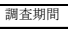 & 通年錐盉 & 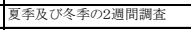 & 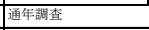 & & 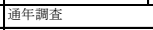 & & & 通年謂查 & & \\
\hline $\begin{array}{c}\overrightarrow{\widetilde{F}} \text { 多の } \\
\text { 表 }\end{array}$ & 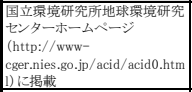 & 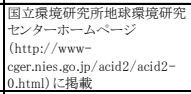 & 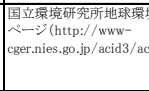 & 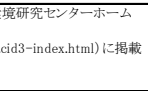 & 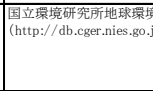 & $\begin{array}{l}\text { 境研究センンターホームム } \\
. j p / \text { dataset/acidrain/ja/ }\end{array}$ & ×ージ/index.htmll) 亿掲栽 & 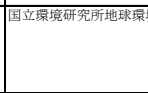 & 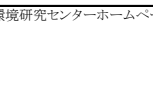 & 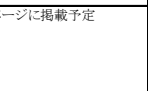 \\
\hline 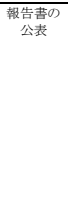 & 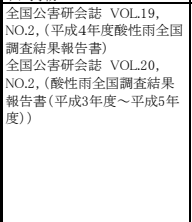 & 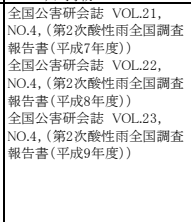 & 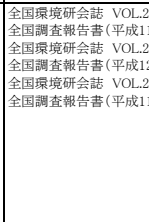 & 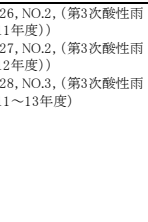 & 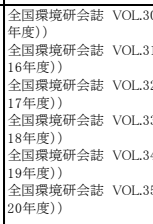 & 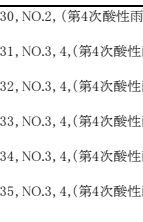 & 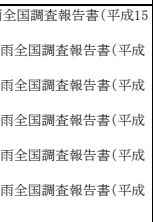 & 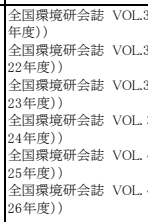 & 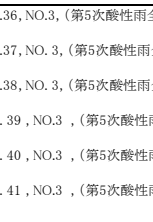 & 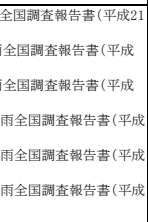 \\
\hline
\end{tabular}


表2.1.1 調査地点の属性および調査内容

\begin{tabular}{|c|c|c|c|c|c|c|c|c|c|c|c|c|c|c|c|c|c|}
\hline . & & & & 排出量 & (iti) $\left(\mathrm{t} \mathrm{km}^{-2}\right.$ & & & & & & & 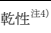 & & & & & \\
\hline $\begin{array}{l}\text { 支 } \\
\text { 部 } \\
\end{array}$ & 纮道付県名 & 地点名 & 洞㚗栈閲名 & $\mathrm{SO}_{2}$ & Nox & $\mathrm{NH}_{3}$ & $\begin{array}{l}\text { 地域区 } \\
\text { 年2) }\end{array}$ & $\begin{array}{l}\text { 緙度 } \\
\text { (度) }\end{array}$ & $\begin{array}{l}\text { 経度 } \\
\text { (度) }\end{array}$ & \begin{tabular}{|l|} 
湿性部 \\
\end{tabular} & FP & O式 & 自動 & $\mid \begin{array}{l}\text { 㛢高 } \\
(\mathrm{m})\end{array}$ & 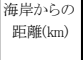 & 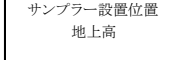 & 土地利用なと \\
\hline & & 利层 & 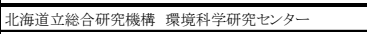 & 1.27 & 0.51 & 0.02 & $\mathrm{NJ}$ & 45.12 & 141.21 & 2 出 & 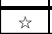 & 0 & 直 & 40 & 0.8 & 地上高?m & 未指定(草、篗) \\
\hline & & $\begin{array}{c}\text { 天監FRS } \\
\end{array}$ & 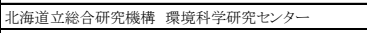 & 0.01 & 0.09 & 0.50 & $\mathrm{NJ}$ & 45.06 & 142.10 & & & - & & 70 & 30 & 地上高8 & 来指定(森林) \\
\hline & 北海道 & 母子里 & 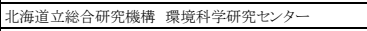 & 0.12 & 0.76 & 0.49 & $\mathrm{NJ}$ & \begin{tabular}{l|l|}
44.36 \\
\end{tabular} & \begin{tabular}{|l|l|l|l}
142.27 \\
\end{tabular} & $\square$ & & 0 & & 287 & 40 & 地上高8奴 & 来指定(椕林) \\
\hline & & 札帺北 & 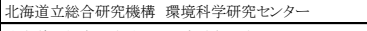 & 5.18 & \begin{tabular}{|l|l|}
25.61 & \\
\end{tabular} & 1.07 & NJ & 43.08 & 141.33 & 络 & 0 & 0 & 罂 & 12 & 13 & Wet: $8 \mathrm{~m}, \mathrm{FP} \cdot 0$ 式:9m & 往居地域(市街地) \\
\hline & & 摩周 & 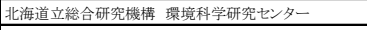 & 0.03 & 0.30 & 1.00 & $\mathrm{NJ}$ & 43.56 & \begin{tabular}{|l|l|}
144.51 \\
\end{tabular} & & & $\Delta$ & & 550 & 30 & 地上高1.5m & 来指定(森林) \\
\hline & & 黒松内 & 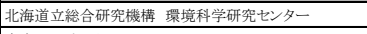 & 0.03 & 0.33 & 0.36 & $\mathrm{NJ}$ & 42.65 & 140.31 & & & $\mathbf{\Delta}$ & & 87 & 13 & 地上高5m & 来指定(森朴) \\
\hline & 青森県 & 青森東造道 & \begin{tabular}{|l|} 
青森県噮境保健ゼンター \\
\end{tabular} & 1.18 & \begin{tabular}{l|l}
3.59 \\
\end{tabular} & $\begin{array}{c}0.44 \\
\end{array}$ & $\mathrm{NJ}$ & 40.83 & 140.79 & $\circ$ & & & & 3 & 0.7 & 地上高20m & 住居地域 (市街地) \\
\hline & & 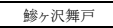 & 青森県環境保健センター & 0.20 & $\begin{array}{ll}.15 \\
\end{array}$ & 0.51 & $\mathrm{NJ}$ & 40.78 & 140.24 & 0 & & & $\Delta$ & 30 & 0.4 & 地上高13m & 都市計画未指定 \\
\hline 北 & 岸手県 & 篮岡 & 岩手県摆境保健研究セン多一 & 1.21 & \begin{tabular}{l|l}
5.94 \\
\end{tabular} & $\begin{array}{l}1.33 \\
\end{array}$ & $\mathrm{NJ}$ & 39.68 & \begin{tabular}{|l|}
141.14 \\
\end{tabular} & & & 0 & & 131 & 70 & 地上高 $12 \mathrm{~m}$ & 淮工業地域 市往地 \\
\hline 海 & 石手泉 & 八幡平 & 岩手具埕境保健研究センター & 0.47 & 1.99 & 1.15 & NJ & 39.82 & \begin{tabular}{|l|l|}
140.94 \\
\end{tabular} & & & 0 & & 830 & 89 & 地上高2m & 麲朴地域 \\
\hline 道 & 宫城県 & 涌谷 & 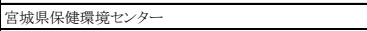 & 1.83 & 5.75 & 2.45 & NJ & 38.55 & \begin{tabular}{|l|l|}
141.18 \\
\end{tabular} & 0 & & & & 165 & 19 & 地上高 $3 \mathrm{~m}$ & 未指定(草、䧴) \\
\hline & 秋田県 & 秋田千秋 & 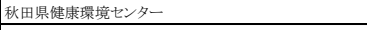 & 4.37 & 6.14 & 0.53 & $\mathrm{NJ}$ & 39.72 & \begin{tabular}{|l|l|}
140.13 \\
\end{tabular} & $\circ$ & & & & 16 & 5.5 & 地上高 $20 \mathrm{~m}$ & 商銹地域 \\
\hline & $\begin{array}{ll}\text { 山形県 } \\
\end{array}$ & $\begin{array}{ll}\text { 推岡 } \\
\end{array}$ & 山形県墿境科学研究セン多一 & 0.12 & \begin{tabular}{l|l}
0.71 \\
\end{tabular} & $\begin{array}{ll}0.38 \\
\end{array}$ & $\mathrm{NJ}$ & $\begin{array}{ll}38.55 \\
\end{array}$ & \begin{tabular}{|l|l|}
139.87 \\
\end{tabular} & & & $\begin{array}{ll}0 \\
\end{array}$ & & 220 & 26. & 地上高5m & 床指定(㯤林) \\
\hline & & 福島天栄 & 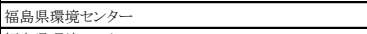 & 0.61 & \begin{tabular}{l|l}
.22 \\
\end{tabular} & $\begin{array}{ll}0.50 \\
\end{array}$ & EJ & 37.25 & \begin{tabular}{|l|}
140.04 \\
\end{tabular} & & & 0 & & 941 & 84 & 地上高1.2m & 田囷 \\
\hline & & 郡山朝日亲10) & 福島県環境センンター & 1.32 & 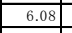 & $\begin{array}{l}1.37 \\
\end{array}$ & EJ & \begin{tabular}{l|l|}
37.41 \\
\end{tabular} & \begin{tabular}{|l|l|}
140.36 \\
\end{tabular} & 0 & & & & 242 & 60 & 地上高10m & 都市 \\
\hline & 福岛具 & 三春 ${ }^{* 1109}$ & 福畠県票境ゼンター & 1.31 & \begin{tabular}{l|l}
6.42 \\
\end{tabular} & $\begin{array}{c}.48 \\
\end{array}$ & EJ & 37.43 & \begin{tabular}{|l|l|}
140.52 \\
\end{tabular} & 0 & & & & 423 & 46 & 地上高 $10 \mathrm{~m}$ & 工栄地域 \\
\hline & & 小名浜 & いわき市環境監視ゼンター & 13.81 & \begin{tabular}{|l|l|}
16.92 \\
\end{tabular} & 0.99 & EJ & 36.96 & \begin{tabular}{|l|l|}
140.89 \\
\end{tabular} & 0 & & 0 & 0 & 3 & 2.5 & Wet: $5 \mathrm{~m}$, , O⿹弋工一: $11.5 \mathrm{~m}$ & 第一種住居地域 \\
\hline & & 新湢兽和 & 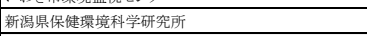 & 2.60 & \begin{tabular}{|l|}
9.49 \\
\end{tabular} & 1.28 & ds & 37.85 & \begin{tabular}{|c|}
138.94 \\
\end{tabular} & 0 & \begin{tabular}{|l|l|l|l|l|l|l}
0 \\
\end{tabular} & & $\Delta$ & 2 & 3.1 & Wet: $2.5 \mathrm{~m}, \mathrm{FP}: 2.1 \mathrm{~m}$ & 市街化誠整区域 \\
\hline & & 長岡 & \begin{tabular}{|l} 
新潟県保健地埧境科学研究所 \\
\end{tabular} & $\begin{array}{ll}1.87 \\
\end{array}$ & \begin{tabular}{l|l}
4.94 \\
\end{tabular} & \begin{tabular}{l|l}
0.62 \\
\end{tabular} & $\frac{\mathrm{ds}}{\mathrm{ds}}$ & 37.45 & \begin{tabular}{|l|}
138.87 \\
\end{tabular} & 0 & \begin{tabular}{|l|l|l|l|l|l|l|l}
0 & \\
\end{tabular} & & 0 & \begin{tabular}{l|l}
27 & -10 \\
\end{tabular} & 19 & 地上高5m & 住居地域 \\
\hline & 新湛県 & 新嘼大山 & 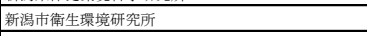 & \begin{tabular}{|l|}
2.75 \\
\end{tabular} & \begin{tabular}{|l|}
12.68 \\
\end{tabular} & 1.74 & J2 & 37.94 & \begin{tabular}{|l|l|}
139.08 \\
\end{tabular} & 0 & & & & 10 & 1.2 & 地上高4m & 住宅地域 \\
\hline & & 新㴡场圾井 & 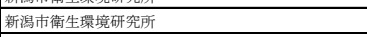 & 2.62 & \begin{tabular}{|r|}
9.59 \\
\end{tabular} & 1.64 & $\mathrm{j}$ & 37.89 & \begin{tabular}{|l|l|}
138.98 \\
\end{tabular} & & & 0 & & 0 & 1.5 & 地上高3m & 住宅地城 \\
\hline & & 新渴小新 & 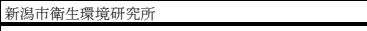 & \begin{tabular}{|l|l|}
2.64 \\
\end{tabular} & \begin{tabular}{|l|}
9.73 \\
\end{tabular} & $\begin{array}{ll}1.66 \\
\end{array}$ & Js & 37.87 & \begin{tabular}{|l|l|}
138.99 \\
\end{tabular} & 0 & 0 & & & 0 & 1.7 & 地上高15m & 住宅地域 \\
\hline & & 日光先场 & 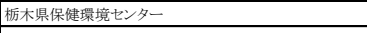 & 0.13 & 0.97 & 0.16 & EJ & 36.74 & \begin{tabular}{|l|l|}
139.48 \\
\end{tabular} & $\circ$ & & & & 1300 & 95 & \begin{tabular}{|l|l|} 
地上高1m \\
\end{tabular} & 倠宅地 \\
\hline & 板木県 & 宇都富目(6) & 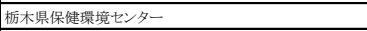 & \begin{tabular}{|l|l|}
2.88 \\
\end{tabular} & \begin{tabular}{|l|}
10.93 \\
\end{tabular} & 2.79 & EJ & 36.60 & \begin{tabular}{|l|l|}
139.94 \\
\end{tabular} & 0 & & & & 140 & 65 & 地上高10m & 住宅地 \\
\hline & & 小山 & 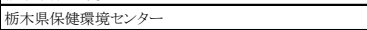 & 3.13 & \begin{tabular}{|l|}
12.59 \\
\end{tabular} & 3.08 & EJ & 36.31 & 139.83 & $\mathrm{O}$ & & & & 35 & 63 & 地上高6m & 住宅地 \\
\hline & & 加資部 & 埼玉具環境科学国国察センター & 2.49 & \begin{tabular}{|l|l|}
18.24 \\
\end{tabular} & 3.51 & EJ & 36.09 & \begin{tabular}{|l|}
139.56 \\
\end{tabular} & $\mathrm{O}$ & \begin{tabular}{|c|}
0 \\
\end{tabular} & $\Delta$ & 0 & 13 & 55 & 地上高 $11 \mathrm{~m}$ & \begin{tabular}{|l|} 
農用地区域 \\
\end{tabular} \\
\hline & 埼玉目 & さいなま & さいたをま市侓康科学斫究七ン多一 & $\begin{array}{r}7.46 \\
\end{array}$ & \begin{tabular}{|l|l|}
48.21 \\
\end{tabular} & 5.19 & EJ & \begin{tabular}{r|r|}
355.86 \\
\end{tabular} & \begin{tabular}{|l|l|}
139.65 \\
\end{tabular} & 0 & & & & 15 & 35 & 地上高15m & 商棠地地域 \\
\hline & 茨城県 & 土浦 & 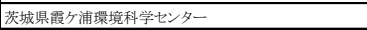 & 1.44 & \begin{tabular}{|l|}
7.73 \\
\end{tabular} & 3.20 & EJ & 36.08 & \begin{tabular}{|l|}
140.27 \\
\end{tabular} & 0 & & & & 18 & 31 & 地上高1m & 未指定(䓥地) \\
\hline & 群馬県 & 前橋 & 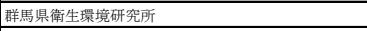 & 4.13 & \begin{tabular}{|l|l|}
12.96 \\
\end{tabular} & 7.55 & EJ & 36.40 & \begin{tabular}{|l|l|}
139.10 \\
\end{tabular} & 0 & \begin{tabular}{|c|}
0 \\
\end{tabular} & & $\mathrm{O}$ & 102 & 110 & 地上高20m & 市街化調整区域 \\
\hline . & & 市川 & 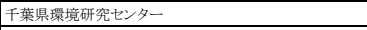 & 8.63 & \begin{tabular}{|l|l|}
59.68 \\
\end{tabular} & \begin{tabular}{l|l|}
4.64 \\
\end{tabular} & EJ & 35.72 & \begin{tabular}{|l|l|}
139.93 \\
\end{tabular} & 0 & & & & 5 & 6.1 & 地上高20m & 倠居地域 \\
\hline 東 & & 市原 & 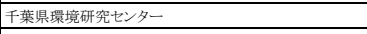 & 13.96 & \begin{tabular}{|l|l|}
44.28 \\
\end{tabular} & $\begin{array}{l}3.14 \\
\end{array}$ & EJ & 35.53 & \begin{tabular}{|l|l|}
140.07 \\
\end{tabular} & o & \begin{tabular}{|l|l|l|l|l|l|l}
0 \\
\end{tabular} & $\Delta$ & & 5 & 1.2 & Wet: $5 \mathrm{~m}, \mathrm{FP}, \mathrm{OAZ}: 10 \mathrm{~m}$ & 工業地域 \\
\hline & & 船子 & 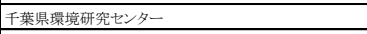 & \begin{tabular}{|l|l|}
10.17 \\
\end{tabular} & \begin{tabular}{|l|}
8.98 \\
\end{tabular} & 3.92 & EJ & 35.74 & \begin{tabular}{|l|l|}
140.74 \\
\end{tabular} & $\circ$ & & & & 50 & 4.5 & 地上高5m & 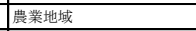 \\
\hline 甲 & & 一宫 & 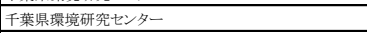 & 0.23 & 1.97 & 0.97 & EJ & 35.35 & 140.38 & 0 & & & & 5 & 1 & 地上高3m & 農業地域 \\
\hline 信 & 千㱳県 & 䞟 & 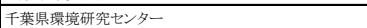 & 7.68 & 8.66 & 4.12 & EI & 35.73 & 140.72 & 0 & 0 & $\mathbf{A}$ & & 58 & 4.7 & 地上高om & 農䍴地域 \\
\hline & & 佐合 & 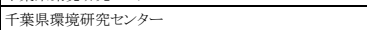 & 2.96 & \begin{tabular}{|l|l|}
26.96 \\
\end{tabular} & 3.01 & EJ & 35.73 & 140.21 & 0 & 0 & $\Delta$ & & 25 & 19 & 地上高3m & 住居地域 \\
\hline 静 & & 清澄 & 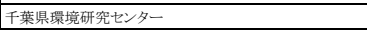 & 0.16 & \begin{tabular}{|l|}
1.14 \\
\end{tabular} & 0.92 & EJ & 35.16 & \begin{tabular}{|l|l|}
140.16 \\
\end{tabular} & $\circ$ & \begin{tabular}{|c|}
0 \\
\end{tabular} & & & 360 & 4.5 & 地上高的 & 米指定(森林) \\
\hline & & 輸浦 & 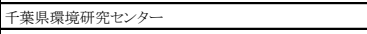 & 0.16 & 1.06 & \begin{tabular}{ll|l}
0.66 \\
\end{tabular} & EJ & 35.18 & \begin{tabular}{|l|l|}
140.27 \\
\end{tabular} & 0 & \begin{tabular}{|l|l|l|l|l|l|l}
0 \\
\end{tabular} & & & \begin{tabular}{c|}
97 \\
\end{tabular} & 4.4 & Wet: $5 \mathrm{~m}, \mathrm{FP}: 3 \mathrm{~m}$, & 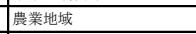 \\
\hline & & 宮野木 & 干葉市渨境保健研究所 & 12.33 & \begin{tabular}{|l|l|}
42.86 \\
\end{tabular} & 3.97 & EJ & 35.65 & \begin{tabular}{|l|l|}
140.10 \\
\end{tabular} & 0 & & & & 21 & 4.1 & 地上高3m & 住居系 \\
\hline & & 平塚 & 神奈川県環境科学センター & $\begin{array}{r}1.42 \\
\end{array}$ & \begin{tabular}{|l|l|}
17.70 \\
\end{tabular} & $\begin{array}{l}3.03 \\
\end{array}$ & EJ & 35.35 & \begin{tabular}{|l|l|}
139.35 \\
\end{tabular} & 0 & & & & 9 & 3.7 & 地上高 $22 \mathrm{~m}$ & 準工業地域 \\
\hline & 神察川県 & 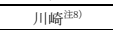 & 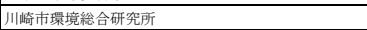 & 16.98 & \begin{tabular}{|l|l|}
74.45 \\
\end{tabular} & 3.11 & EI & 35.54 & 139.75 & 0 & & & & 4 & 3.2 & 地上高 $20 \mathrm{~m}$ & 準工業用地 \\
\hline & 長野県 & 長野 & 長野具與境保全研究所 & $\begin{aligned} 1.35 \\
\end{aligned}$ & \begin{tabular}{|l|}
4.76 \\
\end{tabular} & 0.61 & $\mathrm{CJ}$ & 36.64 & 138.18 & 0 & 0 & & 0 & 363 & 52.5 & Wet: 15m, FP:3m & 第一種住專 \\
\hline & 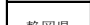 & 静岡小黑 & 静掆市市舆境保健研究所 & 3.29 & \begin{tabular}{|l|l|}
10.23 \\
\end{tabular} & 1.42 & $\mathrm{CJ}$ & 34.97 & 138.40 & 0 & & & & 14 & 3.6 & 地上高的 & 住宅地 \\
\hline & 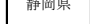 & 静岡北安東 & 静岡県噮境簿生科学研究所 & 3.15 & \begin{tabular}{|l|}
9.89 \\
\end{tabular} & 1.38 & $\mathrm{CJ}$ & 35.00 & 138.39 & 0 & 0 & & & 10 & 7.1 & 地上高9.3m & 住宅地域 (市街地) \\
\hline & 富山県 & 射水被 & 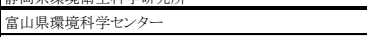 & \begin{tabular}{|c|}
6.11 \\
\end{tabular} & \begin{tabular}{|l|l|}
15.55 \\
\end{tabular} & 1.80 & $\frac{\mathrm{ds}}{\mathrm{d}}$ & 36.70 & \begin{tabular}{|l|l|}
137.10 \\
\end{tabular} & 0 & 0 & $\Delta$ & 0 & 22 & 8 & Wet:0m, FP·O式: $12.5 \mathrm{~m}$ & 第一㮔中高層住宅專用地域 \\
\hline & 石川県 & 金沢 & 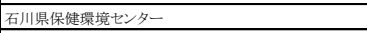 & 2.74 & \begin{tabular}{|l|}
6.93 \\
\end{tabular} & 1.12 & Js & 36.53 & 136.71 & $\circ$ & 0 & & & 120 & 14 & 地上高14m & 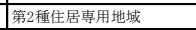 \\
\hline 近 & 福井県 & 福井 & 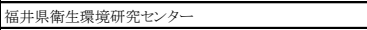 & 2.41 & \begin{tabular}{l|l|l}
7.77 \\
\end{tabular} & $\begin{array}{l}0.80 \\
\end{array}$ & $\mathrm{JS}$ & \begin{tabular}{l|l|}
36.07 \\
\end{tabular} & \begin{tabular}{|l|l}
136.26 \\
\end{tabular} & 0 & 0 & & $\mathrm{O}$ & 11 & 18 & 地上高9m & 市街化調整区域 \\
\hline 䋱 & 岐阜県 & 伊自良湖 & 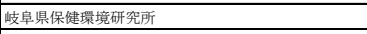 & 2.00 & \begin{tabular}{l|l}
5.52 \\
\end{tabular} & 1.54 & $\mathrm{CJ}$ & 35.57 & 136.70 & 直 & 辛 & & 出 & 140 & 60 & 地上高 $4.3 \mathrm{~m}$ & 林地 \\
\hline & & 豊橋 & 涭知県環境調查センタ一東三河支所 & 2.36 & \begin{tabular}{|l|l|}
10.81 \\
\end{tabular} & 4.18 & $\mathrm{CJ}$ & 34.74 & 137.38 & 0 & 0 & $\Delta$ & 0 & 20 & 6 & 地上高8m & 住居地域 \\
\hline 東 & 路知県 & 名古屋南 & 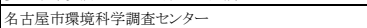 & 10.23 & \begin{tabular}{|l|l|}
51.61 \\
\end{tabular} & 4.70 & $\mathrm{CJ}$ & 35.10 & 136.92 & 0 & 0 & $\mathbf{A}$ & & 0 & & 地上高 $19.2 \mathrm{~m}$ & 㴶工業地域 \\
\hline & 三重県 & 四日市栚 & 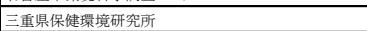 & 4.10 & 17.71 & 2.31 & $\mathrm{CJ}$ & 34.99 & 136.49 & 0 & & & & 190 & 15.1 & 地上高15m & 原野 \\
\hline 北 & 滋賀県 & 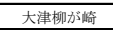 & 琵琶湖罜境科学研究センンタ一 & 3.92 & 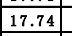 & 1.34 & $\frac{\mathrm{CJ}}{\mathrm{CJ}}$ & 35.03 & \begin{tabular}{|c|c|}
135.87 \\
\end{tabular} & 0 & & & & 87 & 53 & 地上高28m & 住宅地 \\
\hline & 京都疛 & 京都王生 & 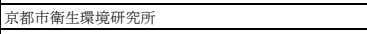 & 3.96 & \begin{tabular}{|c|c|c|c|}
17.81 & & 0
\end{tabular} & 1.65 & CJ & 35.00 & 135.73 & $\circ$ & & & & 26 & 47 & 地上高 $21 \mathrm{~m}$ & 淮工業地域(本街地) \\
\hline & 兵庸県 & 神戸镇磨 & 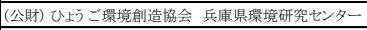 & 10.20 & \begin{tabular}{|l|l|}
30.41 \\
\end{tabular} & 1.05 & $\mathrm{CJ}$ & 34.65 & 135.13 & 0 & 0 & & $\circ$ & 15 & 0.9 & Wet: $29 \mathrm{~m}$, FP: $17 \mathrm{~m}$ & 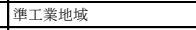 \\
\hline & 和歌山県 & 海南 & 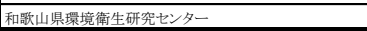 & 9.97 & \begin{tabular}{|l|l|l|l|l|l|}
14.10 \\
\end{tabular} & 1.12 & $\mathrm{CJ}$ & 34.16 & 135.21 & $\mathrm{O}$ & 0 & & $\circ$ & 3 & 0.4 & 地上高12.5m & 旗業 \\
\hline & & 类模 & 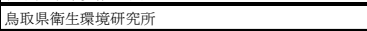 & 0.03 & 0.50 & 0.30 & $\frac{\mathrm{d}}{\mathrm{d}}$ & 35.35 & 134.49 & 0 & & 0 & $\Delta$ & 800 & 28.4 & 地上高2.5m & 未指定 \\
\hline 中 & 鳥取県 & 湯梨浜 & 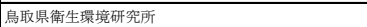 & 0.25 & 1.30 & 0.86 & $\frac{\text { Is }}{3 t}$ & 35.49 & 133.89 & O & 0 & 0 & & 2 & 1.3 & 地上高11m & 未指定 \\
\hline 国 & 島根県 & 松江 & 島根県保煡嘸境科学研究所 & 0.46 & 2.49 & 0.56 & Js & 35.47 & \begin{tabular}{|l|}
133.01 \\
\end{tabular} & o & & & & f & . & 地上高1.2m & 区域外 \\
\hline & 広島県 & 広島安佐南 & \begin{tabular}{|l|} 
広島市衛生研究所 \\
\end{tabular} & 3.35 & \begin{tabular}{|l|}
12.32 \\
\end{tabular} & 1.04 & $\frac{w}{w J}$ & 34.46 & \begin{tabular}{|l|}
132.41 \\
\end{tabular} & 0 & & & & 80 & 11 & 地上高10m & 住居地域 \\
\hline 四 & 山口県 & 山口 & 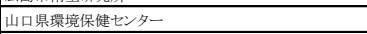 & 2.28 & \begin{tabular}{l|l|l}
5.84 & \\
\end{tabular} & 0.63 & wJ & 34.15 & 131.43 & 0 & & & & \begin{tabular}{l|l}
13 \\
\end{tabular} & 13 & 地上高1m & 隹居地域 \\
\hline & 德岛県 & 德島 & 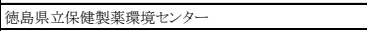 & 2.04 & \begin{tabular}{l|l}
8.03 \\
\end{tabular} & $\begin{array}{c}1.76 \\
\end{array}$ & CJ & \begin{tabular}{ll|}
34.07 \\
\end{tabular} & \begin{tabular}{|l|l|}
134.56 \\
\end{tabular} & 0 & & & & 2 & 3 & 地上高18m & 住居地域 \\
\hline & 高知県 & 香北 & 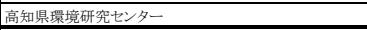 & 0.04 & 0.46 & 0.18 & wJ & \begin{tabular}{ll|}
33.71 \\
\end{tabular} & \begin{tabular}{|l|l|}
133.86 \\
\end{tabular} & o & 0 & 0 & & 230 & 21 & 地上高11.4m & 区城外 \\
\hline & 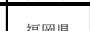 & 太幸附 & 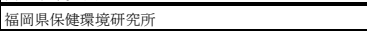 & 3.94 & \begin{tabular}{|l|l|}
21.34 \\
\end{tabular} & 1.90 & wJ & 33.51 & 130.50 & 0 & 0 & & 0 & 30 & 15 & Wet: $16.4 \mathrm{~m}$, FP: $5.1 \mathrm{~m}$ & 市街化調整区域 \\
\hline & 福岡県 & 福岡 & 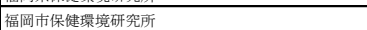 & 2.43 & \begin{tabular}{|l|l|}
14.89 \\
\end{tabular} & 1.38 & WJ & 33.50 & \begin{tabular}{|l|}
130.31 \\
\end{tabular} & 0 & & & & \begin{tabular}{l|l}
193 \\
\end{tabular} & 9.2 & 地上高1m & 市街化調整区域 \\
\hline & 佐賀県 & 俈賀 & 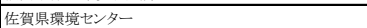 & 2.50 & \begin{tabular}{|l|}
6.92 \\
\end{tabular} & 1.63 & wJ & 33.27 & \begin{tabular}{|l|l|}
130.27 \\
\end{tabular} & 0 & & & & 4 & 11 & 地上高8.5m & 第1種住居地域(市街地) \\
\hline & & 䜕早 & 長崎县睬境保健研究セン多一 & 5.88 & \begin{tabular}{l|l}
7.58 \\
\end{tabular} & 1.30 & wJ & 32.86 & \begin{tabular}{|l|l|}
130.04 \\
\end{tabular} & 0 & & & & 23 & & 地上高10m & 住居地域(市街地) \\
\hline & 長峆県 & 長崎 & 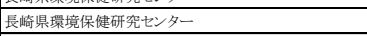 & \begin{tabular}{|l|}
1.17 \\
\end{tabular} & 4.99 & 0.62 & $w_{\mathrm{wJ}}$ & 32.76 & \begin{tabular}{|l|l|}
129.86 \\
\end{tabular} & $\diamond$ & & & & 4 & 1.3 & 地上高2.6m & 通業地地域 \\
\hline & & 佐世保 & 長崎目環境保健研究七ン 名一 & 4.30 & 8.39 & $\begin{array}{l}1.37 \\
\end{array}$ & wJ & 33.18 & \begin{tabular}{|l|l|}
129.72 \\
\end{tabular} & - & & & & \begin{tabular}{l|l}
38 \\
\end{tabular} & 1.3 & 地上高38m & 住居地域(市街地) \\
\hline 九 & & 阿䔩 & 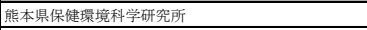 & 0.30 & 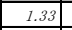 & $\begin{array}{c}1.72 \\
\end{array}$ & WJ & \begin{tabular}{ll|}
32.97 \\
3
\end{tabular} & 131.05 & 0 & & & & 481 & 466 & 地上高3m & 米指定 \\
\hline & & 审士 & 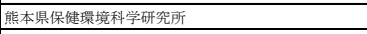 & 2.07 & \begin{tabular}{l|l}
8.38 \\
\end{tabular} & $\begin{aligned} 1.47 \\
\end{aligned}$ & wJ & 32.67 & 130.65 & 0 & & & & 20 & 2.7 & 地上高 $1 \mathrm{~m}$ & 来指定 \\
\hline & 熊本県 & 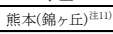 & 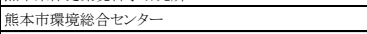 & 1.71 & \begin{tabular}{l|l}
8.83 \\
\end{tabular} & 3.56 & wJ & 32.79 & \begin{tabular}{|l|l|}
130.75 \\
\end{tabular} & o & & $\Delta$ & 0 & 26 & 12.9 & Wet: $9 \mathrm{~m}$, O式: $10 \mathrm{~m}$ & 住宅地域 \\
\hline 綶 & & 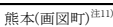 & 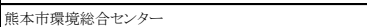 & 1.65 & 8.71 & 2.93 & wJ & 32.76 & 130.73 & 0 & & $\mathbf{A}$ & 0 & 5 & 12.0 & Wet: $14.7 \mathrm{~m}$, O式: $15.7 \mathrm{~m}$ & 市街化調整区域 \\
\hline & & 大分久住 & 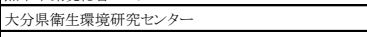 & \begin{tabular}{|l|l|}
2.07 \\
\end{tabular} & 8.38 & 1.47 & $w_{J}$ & 33.04 & \begin{tabular}{|l|l|}
131.25 \\
\end{tabular} & & 0 & & & 560 & 35 & 地上高 $4.7 \mathrm{~m}$ & \begin{tabular}{|l|l|} 
米指定(牧幕地) \\
\end{tabular} \\
\hline & 大分県 & 大分 & 开究セン多一 & 15.09 & \begin{tabular}{|l|l|}
19.72 \\
\end{tabular} & 1.30 & wJ & 33.16 & 131.61 & 0 & $\circ$ & & & 90 & 11 & 地上高14.3m & 住宅地 \\
\hline & 宮崎県 & 宮崎 & 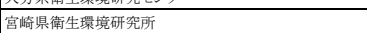 & 0.56 & \begin{tabular}{|l|l|}
3.25 \\
\end{tabular} & 1.14 & WJ & 31.83 & \begin{tabular}{|l|l|}
131.42 \\
\end{tabular} & 0 & 0 & & & 20 & 3.5 & 地上高14m & 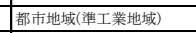 \\
\hline & 覤览易県 & 魔児島 & 蝔児島県環境保健センター & 1.41 & \begin{tabular}{l|l}
5.88 \\
\end{tabular} & $\begin{array}{l}1.37 \\
\end{array}$ & WJ & \begin{tabular}{ll|}
31.35 \\
\end{tabular} & \begin{tabular}{|l|l|}
130.34 \\
\end{tabular} & 0 & $\mathrm{O}$ & & $\Delta$ & & 0.1 & Wet: $4.5 \mathrm{~m}, \mathrm{FP}: 21 \mathrm{~m}$ & 漼工業地 \\
\hline & & 大里 & 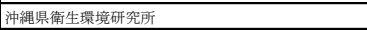 & 6.30 & \begin{tabular}{l|l}
7.83 \\
\end{tabular} & 2.08 & SW & 26.19 & $\begin{array}{ll}127.75 \\
\end{array}$ & $\circ$ & $\circ$ & $\mathbf{\Delta}$ & & 109 & 1.8 & 地上高8m & 来指定 \\
\hline & 沖綶県 & 辺戸拥 & 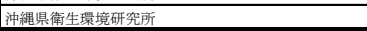 & 0.00 & \begin{tabular}{|l|l|}
0.05 \\
\end{tabular} & 0.35 & SW & 26.87 & 128.25 & 妾 & is & $\Delta$ & 约 & 60 & 0.2 & 地上高4.5m & 铁别地地域 \\
\hline & & & 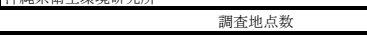 & & & & & & & 68 & 31 & 26 & 21 & & & & \\
\hline
\end{tabular}

用が無理な場合は, 冬季間, バルク捕集となることも可

としている。また，ロート部および導管部の洗浄につい

ては, 月単位の切れ目の日に実施することとし, 洗浄後
にフィールドブランク試料を採取し, 精度管理に用いて いる。

降水量は, 貯水量を捕集面積で割って算出することと 
しており，測定項目および分析方法，手順については， 湿性沈着モニタリング手引き書一第2版一(以下, 手引き

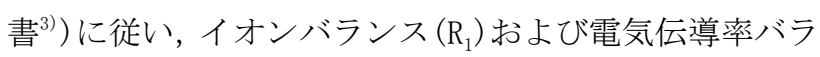
ンス $\left(\mathrm{R}_{2}\right)$ により, 基準範囲を超える場合は, 再分析を行 うなどの精度管理を行っている。また, 分析精度の確保 に関しては, 環境省のモニタリングネットワーク（以下， JADS）の測定局を対象に行われている分析機関間比較調 查に本調查参加機関も多数参加し, 全環研としても解析 を行うことにより, 分析データの信頼性を確保している。

表2.1.2 調査期間の季節 - 月区分

\begin{tabular}{|c|c|c|c|c|}
\hline 季節 & 月 & \multicolumn{2}{|c|}{ 2015年度 } & 週 \\
\hline \multirow{2}{*}{ 春 } & 4 & 4月6日 〜 & 5月7日 & 4 \\
\hline & 5 & 5月7日 〜 & 6月1日 & 4 \\
\hline \multirow{3}{*}{ 夏 } & 6 & 6月1日 〜 & 6月29日 & 4 \\
\hline & 7 & 6月29日 〜 & 7月27日 & 4 \\
\hline & 8 & 7月27日 〜 & 9月7日 & 6 \\
\hline \multirow{3}{*}{ 秋 } & 9 & 9月7日 〜 & 10月5日 & 4 \\
\hline & 10 & 10月5日 〜 & 11月2日 & 4 \\
\hline & 11 & 11月2日 〜 & 11月30日 & 4 \\
\hline \multirow{3}{*}{ 冬 } & 12 & 11月30日 〜 & 12月28日 & 4 \\
\hline & 1 & 12月28日 $~$ & 1月25日 & 4 \\
\hline & 2 & 1月25日 〜 & 3月7日 & 6 \\
\hline 春 & 3 & 3月7日 〜 & 4月4日 & 4 \\
\hline
\end{tabular}

注) 週単位の試料交換日は原則として月曜日とした。

\section{2.2 乾性沈着}

乾性沈着調査はフィルターパック法, パッシブ法およ び自動測定機による方法を採用した。フィルターパック 法，パッシブ法における測定項目別の捕集ろ紙を表 2.2.1に示す。

\section{2. 2.1 フィルターパック法}

フィルターパック法(以下，FP法)は，1段目で粒子状 物質を，2段目で $\mathrm{HNO}_{3}$ などを，3段目で $\mathrm{SO}_{2}$, $\mathrm{HCl}$ を，4段目 でNH 3 を捕集する4段ろ紙法 ${ }^{4}$, 5) 全環研として採用した。 調查地点は, 可能な限り湿性沈着調査地点と同一地点 を選定することとなっており, 通年調査で, 採取単位は 1週間〜2週間である。なお, 解析に用いるデータは月単 位である。試料採取は, 第3 4 次調査 ${ }^{4)}$ と同様に表 2.2 .1 に示した4種のろ紙を装着し, 毎分 1 ～5Lの吸引速度で連 続採取を行い, 積算流量計, あるいは平均流量から採気 量を求めている。

なお, 全環研のFP法に関するマニュアルは東アジア酸 性雨モニタリングネットワーク (以下，EANET) でも英訳 されて用いられており, 詳細な手順などはこれまでの報 告 ${ }^{4)}$ おびEANETの技術資料 ${ }^{6)}$ などを参照されたい。

\section{表2.1.3 全国環境研協議会・酸性雨広域大気污染調査研究部会組織}

\begin{tabular}{|c|c|c|c|c|}
\hline 部会役職 & 所 & 氏 名 & $\begin{array}{l}\text { 担当 } \\
\text { 年度 }\end{array}$ & $\begin{array}{l}\text { 報告書等 } \\
\text { 担当部分 }\end{array}$ \\
\hline 部会長 & 熊本市環境総合センター & 藤井 幸三 & $\mathrm{H} 27-28$ & \\
\hline 理事委員 & 宮崎県衛生環境研究所 & 溑田 洋彦 & $\mathrm{H} 27-28$ & \\
\hline \multirow{6}{*}{ 支部委員 } & 岩手県環境保健研究センター & 多田 敬子 & $\mathrm{H} 27-28$ & $D, 6$ 章 \\
\hline & 埼玉県環境科学国際センター & 松本 利恵 & $\mathrm{H} 27-28$ & D, 5.3章 \\
\hline & 福井県衛生環境研究センター & 川下 博之 & $\mathrm{H} 27$ & \\
\hline & II & 藤田 大介 & $\mathrm{H} 28$ & $D, 4$ 章 \\
\hline & 徳島県立保健製薬環境センター & 河野 明大 & $\mathrm{H} 27-28$ & $D, 4$ 章 \\
\hline & 沖縄県衛生環境研究所 & 友寄 喜貴 & $\mathrm{H} 27-28$ & $D, 1-3$ 章 \\
\hline \multirow{11}{*}{ 委 員 } & $\begin{array}{l}\text { 地方独立行政法人 北海道立総合研究機構 環境・地質研 } \\
\text { 究本部 環境科学研究センター }\end{array}$ & 野口 泉 & $\mathrm{H} 27$ & \\
\hline & ( & 山口 高志 & $\mathrm{H} 27-28$ & 6章 \\
\hline & 新潟県保健環境科学研究所 & 家合 浩明 & $\mathrm{H} 27-28$ & \\
\hline & 千葉県環境研究センター & 横山新紀 & $\mathrm{H} 27-28$ & 6章 \\
\hline & 富山県環境科学センター & 木戸 瑞佳 & $\mathrm{H} 27-28$ & 5.1-5.2章 \\
\hline & 三重県保健環境研究所 & 西山亭 & $\mathrm{H} 28$ & 4章 \\
\hline & $\begin{array}{l}\text { 公益財団法人 ひょうご環境創造協会 兵庫県環境研究セ } \\
\text { ンター }\end{array}$ & 堀江 洋佑 & $\mathrm{H} 27-28$ & 1-4章 \\
\hline & 名古屋市環境科学調査センター & 久恒 邦裕 & $\mathrm{H} 28$ & 4章 \\
\hline & 鳥取県衛生環境研究所 & 山添良太 & $\mathrm{H} 27-28$ & 5.3章 \\
\hline & 福岡県保健環境研究所 & 濱村 研吾 & $\mathrm{H} 27-28$ & 5.1-5.2章 \\
\hline & 沖縄県衛生環境研究所 & 岩崎 綾 & $\mathrm{H} 27-28$ & 1-4章 \\
\hline \multirow{8}{*}{ 有識者 } & 国立大学法人 東京農工大学 農学部 & 松田 和秀 & $\mathrm{H} 27-28$ & \\
\hline & 法政大学 生命科学部 & 村野 健太郎 & $\mathrm{H} 27-28$ & \\
\hline & $\begin{array}{l}\text { 国立研究開発法人 国立環境研究所 地球環境研究セン } \\
\text { 夕ー }\end{array}$ & 向井 人史 & $\mathrm{H} 27-28$ & \\
\hline & 公立大学法人 北九州市立大学 & 藍川昌秀 & $\mathrm{H} 27-28$ & \\
\hline & $\begin{array}{l}\text { 一般財団法人 日本環境衛生センター アジア大気污染研 } \\
\text { 究センター }\end{array}$ & 箕浦 宏明 & $\mathrm{H} 27-28$ & \\
\hline & 大気環境学会中国・四国支部 & 大原 真由美 & $\mathrm{H} 26-27$ & \\
\hline & 環境省 & 小林 登茂子 & $\mathrm{H} 27$ & \\
\hline & 11 & 船越 吾朗 & $\mathrm{H} 28$ & \\
\hline \multirow{3}{*}{ 事務局 } & 熊本市環境総合センター & 甲斐 勇 & $\mathrm{H} 27-28$ & \\
\hline & "I & 濱野 晃 & H27-28 & \\
\hline & II & 吉田 芙美香 & $\mathrm{H} 27-28$ & \\
\hline
\end{tabular}

注）「報告書担当部分」におけるDはデータ収集，数字は報告書の章を表す。 


\section{表2. 2.1 測定項目別の捕集ろ紙}

\begin{tabular}{|c|c|c|}
\hline & 項 目 & 捕集乃紙名 \\
\hline \multirow{5}{*}{$\begin{array}{l}F \\
P\end{array}$} & 粒子状成分 & テフロン (PTFE) \\
\hline & $\mathrm{HNO}_{3}$ & ポリアミド \\
\hline & $\mathrm{SO}_{2}$ & $\mathrm{~K}_{2} \mathrm{CO}_{3}+$ ポリアミド \\
\hline & $\mathrm{HCl}$ & $\mathrm{K}_{2} \mathrm{CO}_{3}+$ ポリアミド \\
\hline & $\mathrm{NH}_{3}$ & リン酸+ポリアミド \\
\hline \multirow{5}{*}{$\begin{array}{l}\text { パ } \\
\text { ツ } \\
\text { シ } \\
\text { ブ }\end{array}$} & $\mathrm{NO}_{2}$ & トリエタノールアミン(TEA) \\
\hline & NOx & TEA+PTIO \\
\hline & $\mathrm{NH}_{3}$ & クエン酸 \\
\hline & $\mathrm{O}_{3}$ & $\mathrm{NaNO}_{2}$ \\
\hline & $\left(\mathrm{SO}_{2}\right)^{*}$ & TEA もしくは $\mathrm{K}_{2} \mathrm{CO}_{3}$ \\
\hline
\end{tabular}

*第5次調查では測定対象外

\subsubsection{2 パッシブ法}

パッシブ法は, 目的のガス成分を捕集するための試薬 が含浸されたろ紙, あるいは目的のガス成分と反応を起 こすための試薬が含浸されたろ紙を用い, 捕集量あるい は試薬成分変化量を測定し, 濃度を求める方法である。 パッシブ法においては, そのまま試薬含浸ろ紙をさらす 方が捕集量は多くなるが, 粒子状物質の沈着や風の強さ などの影響を除くため, 目的ガス成分がろ紙にたどり着 くまでの抵抗を設ける必要がある。本調査では抵抗方法 として, 細孔を開けたサンプラーのカバーによる(拡散 長抵抗)方法である小川式パッシブ法 (以下，パッシブ 法)を用いている。

2015年度のパッシブ法の調査地点は28地点である。 調查地点は大都市(例えば県庁所在地) ・工業地域, 中小 都市地域, 田園地域, 山林地域などからその目的に応じ 1 地点以上選定する。可能ならば 1 地点はフィルターパ ック法 (以下, FP法) 又は自動測定機による測定を実施し ている地点を選定することとなっている。調査は通年で あり，採取単位は原則1ヶ月である。

パッシブ法は, THE OGAWA SAMPLERとして欧米でもモ ニタリングに用いられている方法であり, 測定方法とし てはFP法と同様に世界的にも良く知られている。本方法 は, 拡散長抵抗方法が用いられ, 濃度と捕集量の関係が 理論的に証明されており，他の方法と比較することなく 濃度の算出が可能である。また捕集効率が $100 \%$ に近く, 分子拡散係数が得られれば, 他の成分でも測定が可能で ある。しかし，抵抗が大きく，ブランク值および分析の 定量下限值の影響を受けやすい。特に $\mathrm{SO}_{2}$ に関しては, 都市部以外の地域では精度の高い測定結果を得るのは 困難であるため第5次調查では測定対象となっていない。 しかし, 従来のマニュアル7で用いられていたトリエタ ノールアミン (TEA) ではなく, $\mathrm{K}_{2} \mathrm{CO}_{3}$ により改良された低 濃度用乃紙の測定結果と, 従来法との換算式も報告され
ている8)。これを受け，メーカーから $\mathrm{K}_{2} \mathrm{CO}_{3}$ 含浸ろ紙が市 販されるようになった。このことにより, 従来のマニュ アルマに加えて，マニュアルとは異なる点を含む全環研 用パッシブ法のマニュアル補足版を作成した。

\section{2. 2.3 自動測定機のデータ}

自動測定機による測定值は, 大気污染常時監視測定局 データなどを月単位に集計し用いている。本データはFP 法およびパッシブ法による測定結果の精度確認のため に用いた。また, 一部は乾性沈着量の評価にも用いてい る。本データには高濃度地域に対応するための常時監視 データも含まれており,一部はFP法より精度が低い場合 もある。2015年度の自動測定機の調查地点は21地点であ る。

\section{2.3 調查地点の属性および調查内容}

広域的な環境調查データを解析する場合, 目的に応じ てデータおよび地点を選択することが有効である。

環境省の酸性雨モニタリング, EANETなどでは, モニタ リングの目的，あるいは発生源 (都市域) からの距離に応 じて調查地点を区分している。これは，モニタリングデ 一タを解析する場合に, この区分に応じて, 近隣の発生 源の影響などを考慮し，対象地点を選択して解析するた めである。

本調査では, Kannariら $\left.(2007)^{9}\right)$ による2000年度ベース の $\mathrm{SO}_{2}, \mathrm{NO}_{\mathrm{X}}$ およびNH $\mathrm{H}_{3}$ 排出量の情報を用いて, 必要に応じ て排出量別の解析を実施した。それぞれの排出量は3次 メッシュ(約 $1 \mathrm{~km}$ 四方)で得られており, 調查地点周辺 (半 径 $20 \mathrm{~km}$ 相当: 対象範囲は, 測定地点を中心とした半径 $20 \mathrm{~km} の 円 内 に 3$ 次メッシュの中心点が存在するメッシュ とした。)の排出量を算出した。

\section{一 引用文献 -}

1）母子里のデータは, 北大北方生物圈フィールド科学 センターとの共同研究による。

2）天塩FRSのデータは, 国立環境研地球環境研究センタ 一, 北大北方生物圈フィールド科学センターおよび北 大工学研究科との共同研究による。

3）環境省環境保全対策課：湿性沈着モニタリング手引 き書 (第2版)， 2001

http://www. env. go. jp/air/acidrain/man/wet_deposi /index. html

4）全環研：第3次酸性雨全国調査報告書 (平成11 13年 度のまとめ)，全国環境研会誌，28，2-196，2003

5）松本光弘, 村野健太郎：インファレンシャル法によ る樹木等への乾性沈着量の評価と樹木衰退の一考察,

日本化学会誌，1998 (7)，495-505，1998

6) Acid Deposition Monitoring Network in East Asia 
: 東アジアにおけるフィルターパック法に関する技術資 料, http://www. eanet.cc/jpn/docea_f. html

7）平野耕一郎, 斉藤勝美 : 短期暴露用拡散型サンプラ 一を用いた環境大気中の $\mathrm{NO}, \mathrm{NO}_{2}, \mathrm{SO}_{2}, \mathrm{O}_{3}$ および $\mathrm{NH}_{3}$ 濃 度の測定方法 (改訂版), 2010年8月

http://www. city. yokohama. 1g. jp/kankyo/mamoru/ken kyu/shiryo/pub/d0001/d0001.pdf
8）恵花孝昭，野口泉，樋口慶郎，2009.0式パッシブサ ンプラー法における $\mathrm{SO}_{2}$ 捕集剂の検討 (第2 報)。第50回 大気環境学会年会講演要旨集, p. 437

9) A. Kannari, Y. Tonooka, T. Baba, K. Murano : Development of multiple-species $1 \mathrm{~km} \times 1 \mathrm{~km}$ resolution hourly basis emissions inventory for Japan, Atmos. Environ., 41, 3428-3439, 2007 


\section{3. 気象概況および大気污染物質排出量の状況}

降水量が多い場合, 湿性沈着成分濃度は低下寸るが, 沈着量は増加する。また気温および日射は乾性沈着成分 の生成や存在形態に影響すると考えられる。一方, $\mathrm{SO}_{2}$, $\mathrm{NO}_{\mathrm{X}}$ およびアンモニア $\mathrm{NH}_{3}$ 排出量の状況も成分濃度や沈着 量に反映されると考えられる。これらのことから，ここ では気象概況および大気污染物質排出量の状況を示す。

\subsection{5 年度の気象概況}

2015年度の概況は, 以下のとおりである。平均気温は, 夏から秋の一時期を除き，全国的に高温傾向が続いた。 ただし，西日本では2年連続の冷夏となった。9月上旬に は, 台風第17号と第18号の接近により, 関東地方や東北 地方では記録的な大雨となり, 河川の氾濫など甚大な災 害が発生した（「平成27年9月関東・東北豪雨」と命名）。

春の平均気温は, 北・東・西日本ではかなり高く, 沖 縄・奄美で高かった。春の降水量は, 北日本で多く, 東 ・西日本, 沖縄・奄美では平年並だった。春の日照時間 は, 北日本, 東日本日本海側ではかなり多く, 東日本太 平洋側, 西日本日本海側で多かった。西日本太平洋側と 沖縄・奄美で平年並だった。

夏の平均気温は, 沖縄・奄美でかなり高く, 北日本で 高かった。一方, 西日本では低かった。東日本では平年 並だった。夏の降水量は, 西日本太平洋側, 沖縄・奄美 でかなり多く, 東日本太平洋側では多かった。東日本日 本海側ではかなり少なく, 北日本太平洋側では少なかっ た。北・西日本日本海側では平年並だった。夏の日照時 間は, 西日本太平洋側でかなり少なく, 西日本日本海側 と沖縄・奄美では少なかった。北・東日本では平年並だ った。

秋の平均気温は, 沖縄・奄美でかなり高く, 北・東・ 西日本は平年並だった。秋の降水量は, 沖縄・奄美でか なり少なく, 東日本日本海側で少なかった。北・東日本 太平洋側では, 特に 9 月上旬の「平成 27 年 9 月関東 ・東北 豪雨」の影響により, 多かった。北日本日本海側と西日 本は平年並だった。秋の日照時間は, 北・東日本太平洋 側, 沖縄・奄美で多く, 北・東日本日本海側と西日本で は平年並だった。

冬の平均気温は, 全国的に高く, 東・西日本はかなり 高かった。冬の降水量は, 全国的に多く, 西日本と沖縄 ・奄美ではかなり多かった。冬の降雪の深さ合計は西日 本日本海側で多かったが，このうち九州北部でかなり多 く, 近畿日本海側や山陰ではかなり少なかった。東日本 で少なく, 北日本でかなり少なかった。西日本太平洋側 では平年並だった。冬の最深積雪は, 東日本太平洋側で 多い所が多かった。冬の日照時間は, 沖縄・奄美でかな り少なく, 北・西日本日本海側で少なかった。北・西日
本太平洋側と東日本は平年並だった ${ }^{1)}$ 。

黄砂観測日数は前年度 17 日に対し，9日と減少した ${ }^{2)}$ 。 2015年度の各月における降水量, 気温および日射 (日 照時間)の概況を表 3.1 .1 に示す。

\section{$3.2 \mathrm{SO}_{2}, \mathrm{NO}_{x}$ などの排出量のトレンドと分布}

北東アジアにおける人為起源の $\mathrm{SO}_{2}$ およびNo $\mathrm{O}_{\mathrm{x}}$ 排出量は, 中国およびインド，極東ロシアが多い3)。また図 3.2 .1 に示す中国の $\mathrm{SO}_{2}, \mathrm{NO}_{x}$ 排出量のトレンド, $\left.{ }^{4}\right)$ は, 図3.2.2 に示寸中国, 韓国および日本のエネルギー消費のトレン ド6)とも合致しており，90年代半ばから 2000 年頃までは やや停滞したが, その後再び排出量が増加し, 2007年以 降, $\mathrm{SO}_{2}$ 排出量が漸減したとの報告7 もあるが, その排出 量は多いままである。NOX排出量については，2010年度 以降減少傾向にあるが，排出量は多いままである。

国内における人為発生源由来の $\mathrm{SO}_{2}, \mathrm{NO}_{\mathrm{X}}$ および $\mathrm{NH}_{3}$ 排出 量では， $\mathrm{SO}_{2}$ およびNO $\mathrm{N}_{\mathrm{X}}$ 排出量は関東から北九州にかけて の工業地帯および高速道路などの幹線道路近傍の排出 量が多い8)。また $\mathrm{NH}_{3}$ 排出量は酪農などを含む農業 部門 からの排出も多い傾向がみられる。なお，1995年度の分 布と比べると幹線道路近傍の $\mathrm{SO}_{2}$ 排出量は減少しており, 軽油の硫黄分削減効果が認められている ${ }^{9)}$ 。

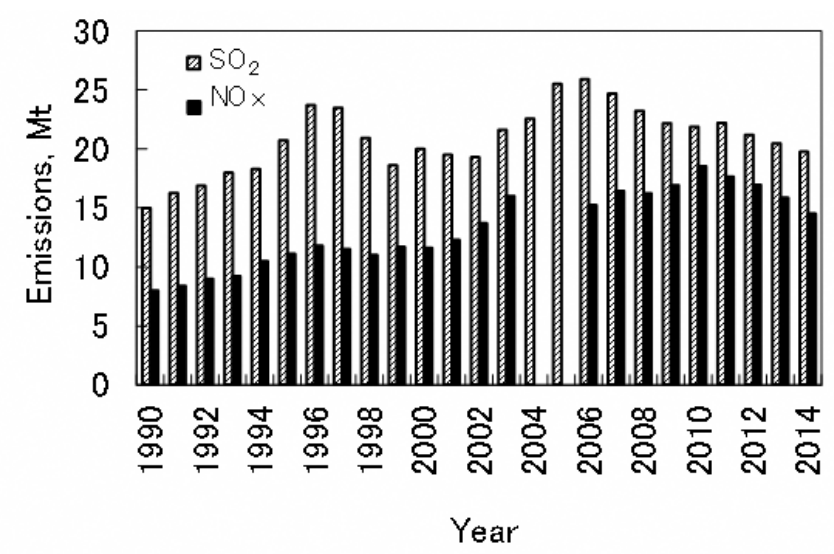

図3.2.1 中国における $\mathrm{SO}_{2}$ おびN $\mathrm{O}_{\mathrm{x}}$ 排出量

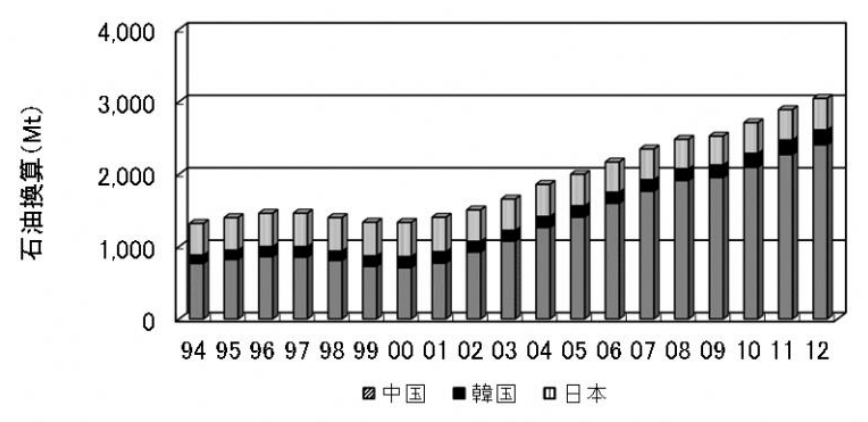

図3.2.2 中国, 韓国および日本のエネルギ一消費の トレンド 


\section{表3.1.1 気象概況 (http://www. jma. go. jp/jma/press/tenko. html)}

\section{平均気温}

\begin{tabular}{|c|c|}
\hline 4月 & 西日本でかなり高く、北・東日本と沖縄・奄美で高かった。釧路(北海道)で4月の月平均気温の高い方から1位の值を更新した。 \\
\hline 5月 & 全国的にかなり高かった。札幌(北海道)、青森(青森県)など55地点で5月の月平均気温の高い方から1位の值を更新した。 \\
\hline 6月 & $\begin{array}{l}\text { 月平均気温は、沖縄・奄美でかなり高く、平年を } 1^{\circ} \mathrm{C} \text { 以上上回った。与那国島、西表島、石垣島、宮古島、久米島 (以上、沖縄県) では6月の月平均気 } \\
\text { 具高い方からの1位の值を更新した。一方、西日本では低かった。北・東日本では平年並だった。 }\end{array}$ \\
\hline 7月 & 北・東日本で高く、西日本で低かった。沖縄・奄美では平年並だった。 \\
\hline 8月 & 西日本で低かった。北・東日本と沖縄・奄美では平年並だった。 \\
\hline 9月 & 東・西日本で低く、北日本と沖縄・奄美では平年並だった。 \\
\hline 10月 & 北日本で低く、東・西日本と沖縄・奄美では平年並だった。 \\
\hline 11月 & 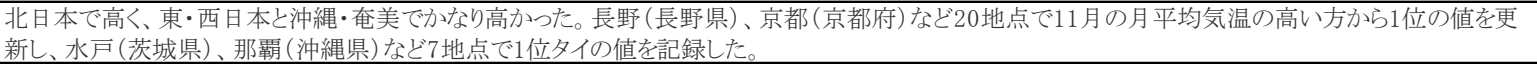 \\
\hline 12月 & $\begin{array}{l}\text { 全国的にかなり高かった。横浜(神奈川県)、高松(香川県)など19地点で12月の平均気温の高い方から1位の值を更新し、京都(京都府)、神戸(兵庫 } \\
\text { 県)など5地点で1位タイの值を記録した。 }\end{array}$ \\
\hline 1月 & 東・西日本と沖縄・奄美で高かった。北日本では平年並だった。 \\
\hline 2月 & 北・東日本は高かった。父島 (東京都)では2月の月平均気温の高い方から1位の值を更新した。西日本と沖縄・奄美は平年並だった。 \\
\hline 3月 & $\begin{array}{l}\text { 東・西日本ではかなり高く、北日本で高かった。若松（福島県）、岐阜、高山(以上、岐阜県)では3月の月平均気温の高い方から1位の值を更新し、福 } \\
\text { 島(福島県)、名古屋(愛知県)、津山(岡山県)では、高いから縄・奄美では平年並だった。 }\end{array}$ \\
\hline \multicolumn{2}{|r|}{ 降水量 } \\
\hline 4月 & $\begin{array}{l}\text { 西日本日本海側でかなり多く、北日本と東日本日本海側、西日本太平洋側、沖縄・奄美で多かった。米子(鳥取県)、清水 (高知県)で4月の月降水 } \\
\text { 量の多い方か位の值を更新した。東日本太洋側では平年並だった。 }\end{array}$ \\
\hline 5月 & 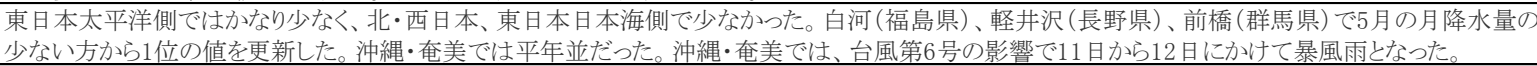 \\
\hline 6月 & 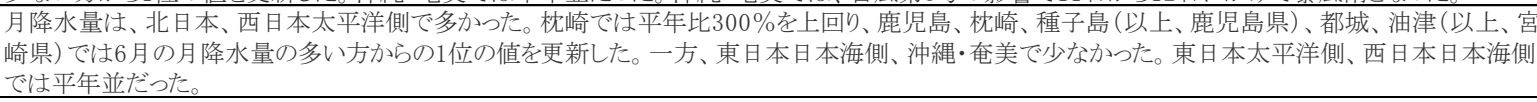 \\
\hline 7月 & 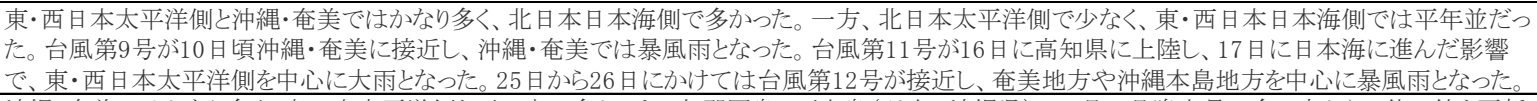 \\
\hline 8月 & 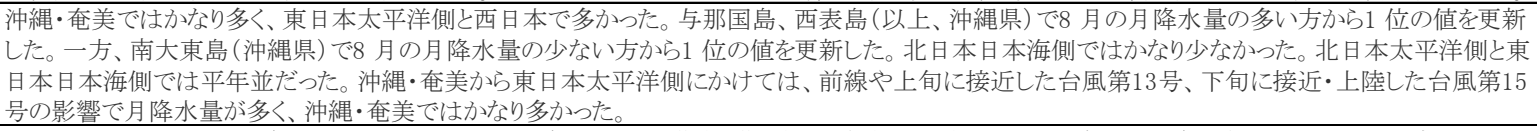 \\
\hline 9月 & 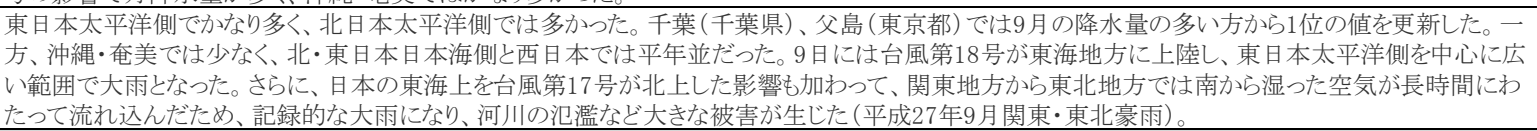 \\
\hline 10月 & 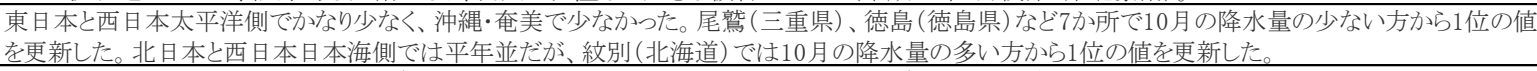 \\
\hline 11月 & $\begin{array}{l}\text { 東日本太平洋側と西日本日本海側で多く、北日本太平洋側と西日本太平洋側でかなり多かった。一方、北日本日本海側では少なかった。東日本日 } \\
\text { 本海側と沖縄・奄美は平年並たった。 }\end{array}$ \\
\hline 12月 & 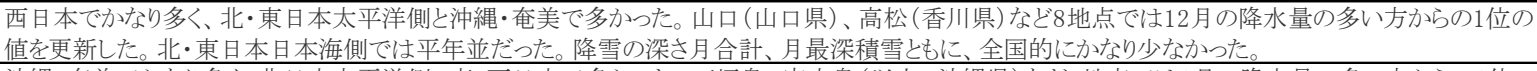 \\
\hline 1月 & 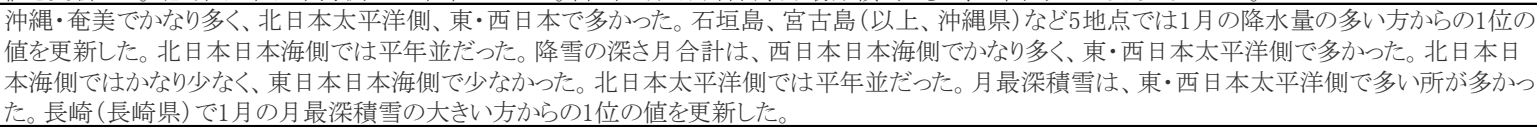 \\
\hline 2月 & $\begin{array}{l}\text { 全国的に多く、北日本日本海側ではかなり多かった。与那国島(沖縄県)では2月の降水量の多い方から1位の值を更新した。降雪の深さ月合計は北・ } \\
\text { 東日本日本海側と西日本で少なく、東日本太平洋側でかなり少なかった。北日本太平洋側で平年並だった。月最深積雪は全国的に少ない所が多 } \\
\text { かった。 }\end{array}$ \\
\hline 3月 & 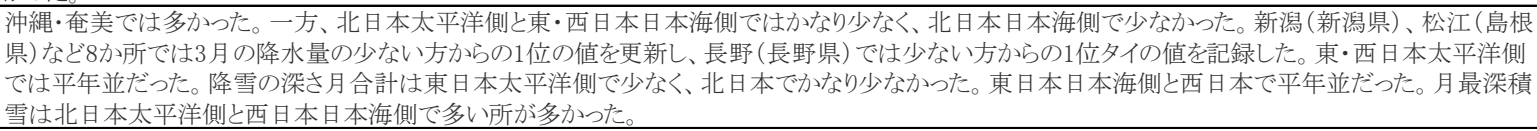 \\
\hline
\end{tabular}

\section{日照時間}

\begin{tabular}{|c|c|}
\hline 4月 & $\begin{array}{l}\text { 東・西日本太平洋側ではかなり少なかった。西日本日本海側では少なかった。北日本日本海側では多かった。北日本太平洋側と東日本日本海側、 } \\
\text { 縄・奄美では平年並だった。 }\end{array}$ \\
\hline 5月 & $\begin{array}{l}\text { •東日本ではかなり多く、山形(山形県)、宇都宫(栃木県)など11地点で5月の月間日照時間の多い方から1位の值を更新した。西日本では多かっ } \\
\text { 。沖縄・奄美では平年並だった。 }\end{array}$ \\
\hline 6月 & $\begin{array}{l}\text { 月間日照時間は、西日本太平洋側でかなり少なく、北日本日本海側、西日本日本海側で少なかった。一方、沖縄・奄美ではかなり多く、東日本日本 } \\
\text { 海側で多かった。北・東日本太平洋側では平年並だった。 }\end{array}$ \\
\hline 7月 & 西日本と沖縄・奄美で少なかった。一方、北日本太平洋側でかなり多く、北日本日本海側、東日本で平年並だった。 \\
\hline 8月 & 縄・奄美でかなり少なく、北日本日本海側と東日本太平洋側で少なかった。北日本太平洋側と東日本日本海側、西日 \\
\hline 9月 & 北·東日本日本海側で少なかった。北・東日本太平洋側、西日本と沖縄・奄美では平年並だった。 \\
\hline 0月 & $\begin{array}{l}\text { 北日本太平洋側と東・西日本でかなり多く、北日本日本海側で多かった。仙台(宮城県)、神戸(兵庫県)など37か所で10月の日照時間の多い方から1 } \\
\text { 位の值を更新した。沖縄・奄美では平年並だった。 }\end{array}$ \\
\hline 11) & $\begin{array}{l}\text { 東日本日本海側で少なく、北・東日本太平洋側と西日本でかなり少なかった。大分(大分県)、徳島(徳島県)など5地点で11月の月間日照時間の少な } \\
\text { い方から1位の值を更新した。一方、北日本日本海側と沖縄・奄美では多かった。 }\end{array}$ \\
\hline 2) & 本海側で多かった。沖縄・奄美ではかなり少なく、東日本太平洋側と西日本日本海側で少なかった。西日本太平洋側では平年並 \\
\hline 1月 & $\begin{array}{l}\text { 東日本太平洋側で多かった。東日本日本海側、西日本、沖縄・奄美ではかなり少なく、北日本で少なかった。酒田（山形県）、新潟(新潟県）、人吉(熊 } \\
\text { 本県)で1月の日照時間の少ない方からの1位の值を更新した。 }\end{array}$ \\
\hline 2月 & $\begin{array}{l}\text { 北日本日本海側では少なかった。稚内、羽幌(以上、北海道)では2月の月間日照時間の少ない方から1位の值を更新した。東日本日本海側と西日 } \\
\text { では多かった。若松(福島県)では2月の月間日照時間の多い方から1位の值を更新した。北・東日本太平洋側および沖縄・奄美は平年並だ゙た。 }\end{array}$ \\
\hline & 西日本日本海側ではかなり多く、北・東日本日本海側と西日本太平洋側で多かった。東日本太平洋側と沖縄·奄美では \\
\hline
\end{tabular}




\section{- 引用文献 -}

1）気象庁報道発表資料, http://www. jma. go. jp/jma /press/tenko. html, 2015

2) 気象庁: 黄砂, http://www. data. jma. go. jp/gmd/env/ kosahp/kosa_table_2015.htm1, 2015

3) J. Kurokawa, T. Ohara, T. Morikawa, S. Hanayama, G. Janssens-Maenhout, T. Fukui, K. Kawashima, and H. Akimoto:Emissions of air pollutants and greenhouse gases over Asian regions during 20002008: Regional Emission inventory in ASia (REAS) version 2, Atmos. Chem. Phys, 13, 11019-11058, 2013

4）国家环境保护总局：http://zls. mep. gov. cn/hjtj/ nb/2013tjnb/201411/t20141124_291867.htm, 2014など

5) H. Tian, J. Hao, Y. Nie: Recent trends of $\mathrm{NO}_{\mathrm{X}}$
Emissions from energy use in China, Proceeding of 7th International Conference on Acidic Deposition, 32, 2005

6）環境省環境統計集, http://www. env. go.jp/doc/ toukei/contents/, 2015

7）大原利眞 : 東アジアにおける広域越境大気污染モデ リングの最新動向，水環境学会誌，35，6-9，2013

8) A. Kannari, Y. Tonooka, T. Baba, K. Murano : Development of multiple-species $1 \mathrm{~km} \times 1 \mathrm{~km}$ resolution hourly basis emissions inventory for Japan, Atmos. Environ., 41, 3428-3439, 2007

9）都市環境学教材編集委員会: 都市環境学, 森北出版, 2003 


\section{4. 湿性沈着}

湿性沈着調査では，日本全域における湿性沈着による 污染実態を把握することが主目的である。ここでは, 湿 性沈着調査における，2015年度のとりまとめについて報 告する。

2015年度の湿性沈着調査に対し，45機関68地点の参加 があった。ただし，4.1で示すとおりデータの精度が基準 を満たしていない地点については，参考值として扱い， 解析からは除外した。

なお, 報告值の一部には, 他の学術機関との共同研究 および国設局との共用データも含まれている（表2.1.1 参照）。

\section{1 データの精度}

地域別・季節別のイオン成分の挙動等について解析す る前に, 各機関の測定データの精度について, 以下の評 価を行った。

\section{1.1 データの完全度}

各機関から報告されたデー夕において，月間または年 間データ同士を比較検討寸る場合, 久測を考慮したデー タの完全度が高いことだけでなく, 各データ間の測定 (試 料採取）期間のズレ（適合度）が小さいことも重要であ る。そこで, 各機関から報告されたデータについて, 全 国環境研協議会酸性雨広域大気污染調查研究部会 (以下, 全環研）で指定した月区切りに基づいて, 完全度（測定 期間の適合度を含む)の評価を行った。定義については, 既報1を参照頂きたい。

完全度を基に，月間データの場合は60％未満，年間デ ータの場合は 80 \%未満のデータについては解析対象から 除外した。ただし，月間データの完全度は基準以下であ るがデータが存在する場合，年間データの集計には用い ている。

2015年度は, 月間データでは790個中 57 データ (7. $3 \%)$ が除外され, 年間データでは68地点中8地点が除外された。 年間データが除外された 8 地点には, 年度内でサンプリン グ地点を変更したため完全度が基準を満たさなかった 3 地点を含む。除外されたデータは参考值として扱った。 なお，装置の故障等により，ある期間常時開放捕集とな
った地点については，原則としてその期間のデータを参 考值扱いとした。

\subsection{2 イオンバランス $\left(R_{1}\right)$ および電気伝導率 バランス $\left(R_{2}\right)$ と分析精度管理調查結果}

表4.1.1に示すように，「湿性沈着モニタリング手引き 書（第2版）」 ${ }^{2)}$ に従って，イオンバランス（以下， $\mathrm{R}_{1}$ ) および電気伝導率バランス（以下， $\mathrm{R}_{2}$ ) による2つの検定 方法を用い，測定值の信頼性を評価した。なお，各機関 における試料の採取および分析は, 原則週単位で行われ ているため, 本来, $\mathrm{R}_{1}$ およびR 2 は個々の試料毎に評価す心゙ きである。しかし，全環研への報告值は月区切りを採用 しているため, 本報告では月単位の加重平均值を用いて, $\mathrm{R}_{1}$ およびR 2 を評価した。

完全度の基準を満たした地点の月間データにおいて, $\mathrm{R}_{1}$ による評価では, 全ての項目が測定された790個のデー タ中， $\mathrm{R}_{1}$ が許容範囲内にあったデータは765個 (適合率 $96.8 \%$ )であった。同様に, $\mathrm{R}_{2}$ による評価では, $\mathrm{R}_{2}$ が許容 範囲内にあったデータは781個 (適合率98.9\%)であった。 $\mathrm{R}_{1}$ および $\mathrm{R}_{2}$ の分布を図4.1.1に示す。2004〜2014年度にお ける $\mathrm{R}_{1}$ および $\mathrm{R}_{2}$ の適合率は, $\mathrm{R}_{1}:$ 92〜97\%， $\mathrm{R}_{2}: 97 \sim 99 \%$ の範囲にあり高いレベルで保たれている

次に，分析精度管理調査について検討した。環境省が 国設大気環境・酸性雨測定所（以下，国設局）を有寸る 自治体を対象に行っている酸性雨測定分析機関間比較調 查は，全環研から環境省への要望により，国設局以外の 希望自治体についても分析精度管理調査（分析機関間比 較調查）として実施されている。同調查は，模擬酸性雨 試料（高濃度および低濃度の2種類）を各機関に配布し， その分析結果を解析することにより，分析機関に存在す る問題点や測定の信頼性の評価を行っている。環境省の 協力のもと，2015年度は全環研会員の自治体のうち国設 局を管理している機関（以下，国設局管理機関）18機関 を除き37機関（以下，精度管理参加機関）がこの調査に 参加した。このうち全環研に湿性沈着の結果を報告して いる機関（以下，全環研報告機関）は31機関であった。 精度管理機関による測定成分毎のフラグ数と相対標準 偏差を表4.1.2に示す。フラグ数は, 東アジア酸性雨モニ

表4.1.1 イオンバランス $\left(R_{1}\right)$ および電気伝導率バランス $\left(R_{2}\right)$ の許容範囲

\begin{tabular}{|c|c|c|c|}
\hline $\begin{array}{c}\Sigma \mathrm{C}_{\mathrm{i}}+\Sigma \mathrm{A}_{\mathrm{i}} \\
(\mu \mathrm{eq} \mathrm{L})\end{array}$ & $\begin{array}{c}\mathrm{R}_{1}(\%)= \\
\left\{\left(\Sigma \mathrm{C}_{\mathrm{i}}-\Sigma \mathrm{A}_{\mathrm{i}}\right) /\left(\Sigma \mathrm{C}_{\mathrm{i}}+\Sigma \mathrm{A}_{\mathrm{i}}\right)\right\} \times 100\end{array}$ & $\begin{array}{c}\Lambda_{\text {obs }} \\
\left(\mathrm{mS} \mathrm{m}^{-1}\right)\end{array}$ & $\begin{array}{c}\mathrm{R}_{2}(\%)= \\
\left\{\left(\Lambda_{\text {cal }}-\Lambda_{\text {obs }}\right) /\left(\Lambda_{\text {cal }}+\Lambda_{\text {obs }}\right)\right\} \times 100\end{array}$ \\
\hline$<50$ & \pm 30 & $<0.5$ & \pm 20 \\
$50 \sim 100$ & \pm 15 & $0.5 \sim 3.0$ & \pm 13 \\
$>100$ & \pm 8 & $>3.0$ & \pm 9 \\
\hline
\end{tabular}

$\Sigma \mathrm{A}_{\mathrm{i}}=\left[\mathrm{SO}_{4}{ }^{2}\right]+\left[\mathrm{NO}_{3}{ }_{3}\right]+[\mathrm{Cl}] \quad$ 但L, 当量濃度 $\left(\mu \mathrm{eq} \mathrm{L} \mathrm{L}^{-1}\right)$

$\Sigma \mathrm{C}_{\mathrm{i}}=\left[\mathrm{H}^{+}\right]+\left[\mathrm{NH}_{4}^{+}\right]+\left[\mathrm{Na}^{+}\right]+\left[\mathrm{K}^{+}\right]+\left[\mathrm{Ca}^{2+}\right]+\left[\mathrm{Mg}^{2+}\right]$ 但L, 当量濃度 $\left(\mu \mathrm{eq} \mathrm{L}^{-1}\right)$

$\Lambda_{\text {cal }}$ : 測定対象イオンの当量濃度に極限等量電気伝導率を乗じた積算値

$\Lambda_{\mathrm{obb}}:$ 降水試料の電気伝導率測定値 

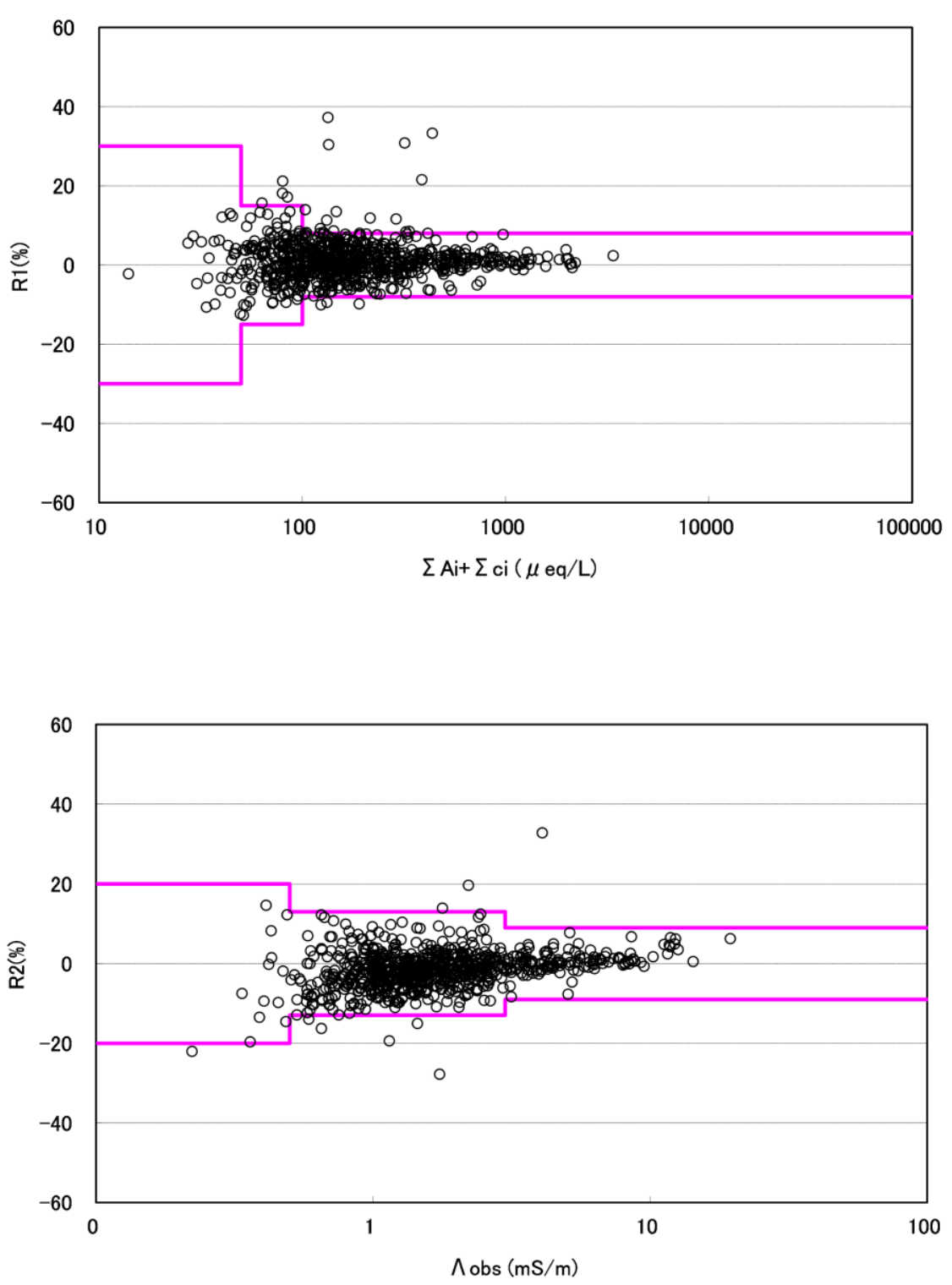

\section{図4.1.1 イオンバランス $\left(R_{1}\right)$ と総イオン濃度 $\left(\sum A i+\Sigma C i\right)$ および電気伝導率バランス $\left(R_{2}\right)$ と実測値との比較}

タリングネットワーク（EANET）の精度管理目標值（DQOs : Data Quality Objectives，分析の正確さ： $\pm 15 \%)$ を 用い, DQ0sの2倍まで $( \pm 15 \%$ 〜 $30 \%)$ の測定值にはフ ラグEを，DQ0sの2倍（土30\%）を超える測定值にはフラ グXを付けて判定した。相対標準偏差を求める際には, 分 析精度管理調查結果報告書 ${ }^{13)}$ の方法に従い, 平均值から 標準偏差の3倍以上はずれている測定值は茟却した。

高濃度試料ではDQ0sを満たすデータが $97.8 \%$ ，フラグE またはフラグXが付いたデータは，それぞれ $1.4 \%$ そおび $0.8 \%$ であった。また, 低濃度試料では, DQ0sを満たすデ ータが93. 6 \% , フラグEまたはフラグXが付いたデータは, それぞれ5.2\%および1. 1\%であった。2014年度 ${ }^{12)}$ に比較し て, 高濃度試料, 低濃度試料ともに, フラグ付与率が減 少し改善が見られた。フラグは陽イオンに多く, 特に低
濃度試料における付与数が多かった。

一方，国設局管理機関（18機関）の2015年度分析精度 管理調査 ${ }^{13)}$ では，高濃度試料ではDQ0sを満たすデータが 100 \%, フラグEまたはフラグXが付いたデータは，それぞ れ0\%であった。低濃度試料では，DQ0sを満たすデータが 98. 9 \%，フラグEまたはフラグXが付いたデータは，それ ぞれ $1.1 \%$ \%おび0\%であった。フラグは全て陽イオンの分 析データに付与された。

次に, 精度管理参加機関間でバラツキの大きな成分を 確認するため, 各成分の測定結果の相対標準偏差を比較 した。高濃度試料については，陰イオンは 4 \%以下で陽イ オンは 6 \%以下, 低濃度試料では陰イオンは7\%以下で陽イ オンは $11 \%$ \%下であった。 $\mathrm{K}^{+}, \mathrm{Ca}^{2+} お よ ひ ゙ \mathrm{Mg}^{2+}$ のバラツキ が大きかった。国設管理機関が2015年度に行った分析精 
度管理調査では，相対標準偏差は高濃度試料については $4 \%$ 以下，低濃度試料については7\%以下であった。

以上の結果から，全環研報告機関と国設局管理機関の フラグの付与率および相対標準偏差を比較すると, 全環 研報告機関のほうがフラグ付与率および相対標準偏差と もに高かった。年々, 分析精度の向上に努め, 概ね精度 よく測定が実施されているが，さらなる改善が望まれる。 特に低濃度試料に関してはより一層の改善が必要である。

各機関の測定結果のバラツキが大きい成分は, 表4.1.2 に示すように, 高濃度, 低濃度試料ともに陽イオンであ り，陽イオンにフラグの付与数が多かった。これらの項 目の分析精度のさらなる向上により, 全体の精度改善に つながることが期待される。また, pHではフラグ付与数 が0であり，バラツキも小さいが， $\mathrm{H}^{+}$濃度に換算すると， 大きなバラツキが予想される。 $\mathrm{R}_{1} お よ ひ ゙ \mathrm{R}_{2}$ の計算過程では $\mathrm{H}^{+}$濃度として効いてくること, 実際の降水試料の評価で は胡沈着量としての評価も重要であることなどから, $\mathrm{pH}$ については， $H^{+}$濃度として測定機関間のバラツキがより 小さくなるよう努力していく必要性が考えられる。

続いて, イオン成分の定量下限值とフラグ付与の関係 について調べた。定量下限值は, イオン成分分析用検量 線を作成する際の最低濃度標準液を5回以上の繰り返し 測定したときの標準偏差 ( $\mathrm{s}$ )から求められる。検出下限值 は3s $\left(\mu \mathrm{mol} \mathrm{L} \mathrm{L}^{-1}\right)$, 定量下限值は10s $\left(\mu \mathrm{mol} \mathrm{L} \mathrm{L}^{-1}\right)$ として計 算される。このため, 定量下限值は, イオン類測定の際 の定量值のバラツキ度合いとみなすことができる。イオ ン成分の定量下限值が定量下限值に係るDQ0sを満たして いない機関数と, その機関のうち分析精度管理調査でフ ラグが付与された機関数について表4.1.3に示した。定量 下限值がDQ0sを満たしていない機関数は， $\mathrm{Ca}^{2+} お よ ひ ゙ \mathrm{Mg}^{2+}$
でそれぞれ2機関 $(5.4 \%)$ であり， $\mathrm{NO}_{3}^{-}, \mathrm{K}^{+} お よ ひ ゙ \mathrm{NH}_{4}^{+}$でそ れぞれ1機関であった。定量下限值がDQ0sを満たしていな い機関のうち，分析精度管理調査の高濃度試料と低濃度 試料でフラグが付与された機関数は， $\mathrm{Ca}^{2+} お よ ひ ゙ \mathrm{Mg}^{2+}$ が 2 機関， $\mathrm{K}^{+}$が1機関であった。フラグが付与されたからとい って定量下限值 $>$ DQ0sであるということではなかったが， 定量下限值 $>\mathrm{DQ} 0 \mathrm{~s}$ の場合にフラグが付与される場合が多 かった。

さらなる分析精度向上のためには, 日常の実降水試料 測定においての $\mathrm{R}_{1}$ および $\mathrm{R}_{2}$ の管理だけにとどまらず,酸性 雨測定分析精度管理調査を積極的に活用し，配布される 模擬酸性雨試料などを「標準参照試料」として利用した 日常的な分析精度の管理を実施していくことが望ましい と考える。

\subsection{3 フィールドブランク}

フィールドブランク（以下，FB）試験を実施する毎に, 各機関にて捕集装置の洗浄確認等の自主管理が実行でき るようにとの目的から，FB試料濃度の上限值（暫定）を 提案した5)。

FB試料から高濃度が検出された場合や，鳥のふん，黄 砂, 虫, 植物片, 種子などの污染に気付いた際は, 採取 装置の洗浄を徹底し，チューブの交換などを実施するこ とで, 流路からの污染を低減化する必要があると考えら れる。また，現場においてはFB試料に濁りや不溶性のコ ンタミネーションがみられないかを確認することや，ポ ータブルの電気伝導率計により電気伝導率を測定するこ とにより，流路からの污染が少なく保たれているかをチ エックすることが望ましい。各機関にてFB試験を実施し, 捕集装置の自主管理を実行することを推奨する。

表4.1.2 分析精度管理調査におけるフラグ数と相対標準偏差

\begin{tabular}{|c|c|c|c|c|c|c|c|c|c|c|c|}
\hline & & $\mathrm{pH}$ & EC & $\mathrm{SO}_{4}{ }^{2-}$ & $\mathrm{NO}_{3}^{-}$ & $\mathrm{Cl}^{-}$ & $\mathrm{Na}^{+}$ & $\mathrm{K}^{+}$ & $\mathrm{Ca}^{2+}$ & $\mathrm{Mg}^{2+}$ & $\mathrm{NH}_{4}^{+}$ \\
\hline \multirow{3}{*}{ 高濃度試料 } & フラグE & 0 & 0 & 1 & 0 & 1 & 1 & 1 & 0 & 1 & 0 \\
\hline & フラグx & 0 & 0 & 1 & 0 & 0 & 0 & 1 & 0 & 1 & 0 \\
\hline & 相対標準偏差 & $\begin{array}{r}1.6 \% \\
(n=37) \\
\end{array}$ & $\begin{array}{r}2.8 \% \\
(n=37) \\
\end{array}$ & $\begin{array}{r}3.4 \% \\
(n=36) \\
\end{array}$ & $\begin{array}{r}3.7 \% \\
(n=36) \\
\end{array}$ & $\begin{array}{r}3.1 \% \\
(n=36) \\
\end{array}$ & $\begin{array}{r}2.4 \% \\
(n=36)\end{array}$ & $\begin{array}{r}5.8 \% \\
(n=36) \\
\end{array}$ & $\begin{array}{r}3.9 \% \\
(n=36) \\
\end{array}$ & $\begin{array}{r}5.1 \% \\
(n=36) \\
\end{array}$ & $\begin{array}{r}2.1 \% \\
(n=36) \\
\end{array}$ \\
\hline \multirow{3}{*}{ 低濃度試料 } & フラグE & 0 & 1 & 2 & 0 & 0 & 2 & 2 & 6 & 4 & 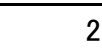 \\
\hline & フラグx & 0 & 0 & 1 & 0 & 1 & 0 & 1 & 0 & 1 & 0 \\
\hline & 相対標準偏差 & $\begin{array}{r}2.2 \% \\
(n=37)\end{array}$ & $\begin{array}{r}4.8 \% \\
(n=37)\end{array}$ & $\begin{array}{r}6.8 \% \\
(n=36)\end{array}$ & $\begin{array}{r}5.5 \% \\
(n=36)\end{array}$ & $\begin{array}{r}3.9 \% \\
(n=36)\end{array}$ & $\begin{array}{r}4 \% \\
(n=36)\end{array}$ & $\begin{array}{r}8.3 \% \\
(n=36)\end{array}$ & $\begin{array}{r}10.6 \% \\
(n=36)\end{array}$ & $\begin{array}{r}7.8 \% \\
(n=36)\end{array}$ & $\begin{array}{r}6.1 \% \\
(n=36)\end{array}$ \\
\hline
\end{tabular}

表4.1.3 定量下限値が精度管理目標値を満たしていない機関数, およびその機関のうち分析精度管理調査で フラグが付与された機関数 $\mathrm{n}=37$

\begin{tabular}{|c|c|c|c|c|c|c|c|c|}
\hline & $\mathrm{SO}_{4}{ }^{2-}$ & $\mathrm{NO}_{3}^{-}$ & $\mathrm{Cl}^{-}$ & $\mathrm{Na}^{+}$ & $\mathrm{K}^{+}$ & $\mathrm{Ca}^{2+}$ & $\mathrm{Mg}^{2+}$ & $\mathrm{NH}_{4}^{+}$ \\
\hline 定量下限値がDQOsを満たしていない機関数 & 0 & 1 & 0 & 0 & 1 & 2 & 2 & 1 \\
\hline 上記機関のうち, 高濃度試料のフラグがついた機関数 & 0 & 0 & 0 & 0 & 0 & 0 & 1 & 0 \\
\hline 上記機関のうち，低濃度試料のフラグがついた機関数 & 0 & 0 & 0 & 0 & 1 & 2 & 1 & 0 \\
\hline 定量下限値に係るDQOs $\left(\mu_{\mathrm{mol} \mathrm{L}} \mathrm{L}^{-1}\right)$ & 0.3 & 0.5 & 0.5 & 0.3 & 0.3 & 0.2 & 0.3 & 0.8 \\
\hline
\end{tabular}




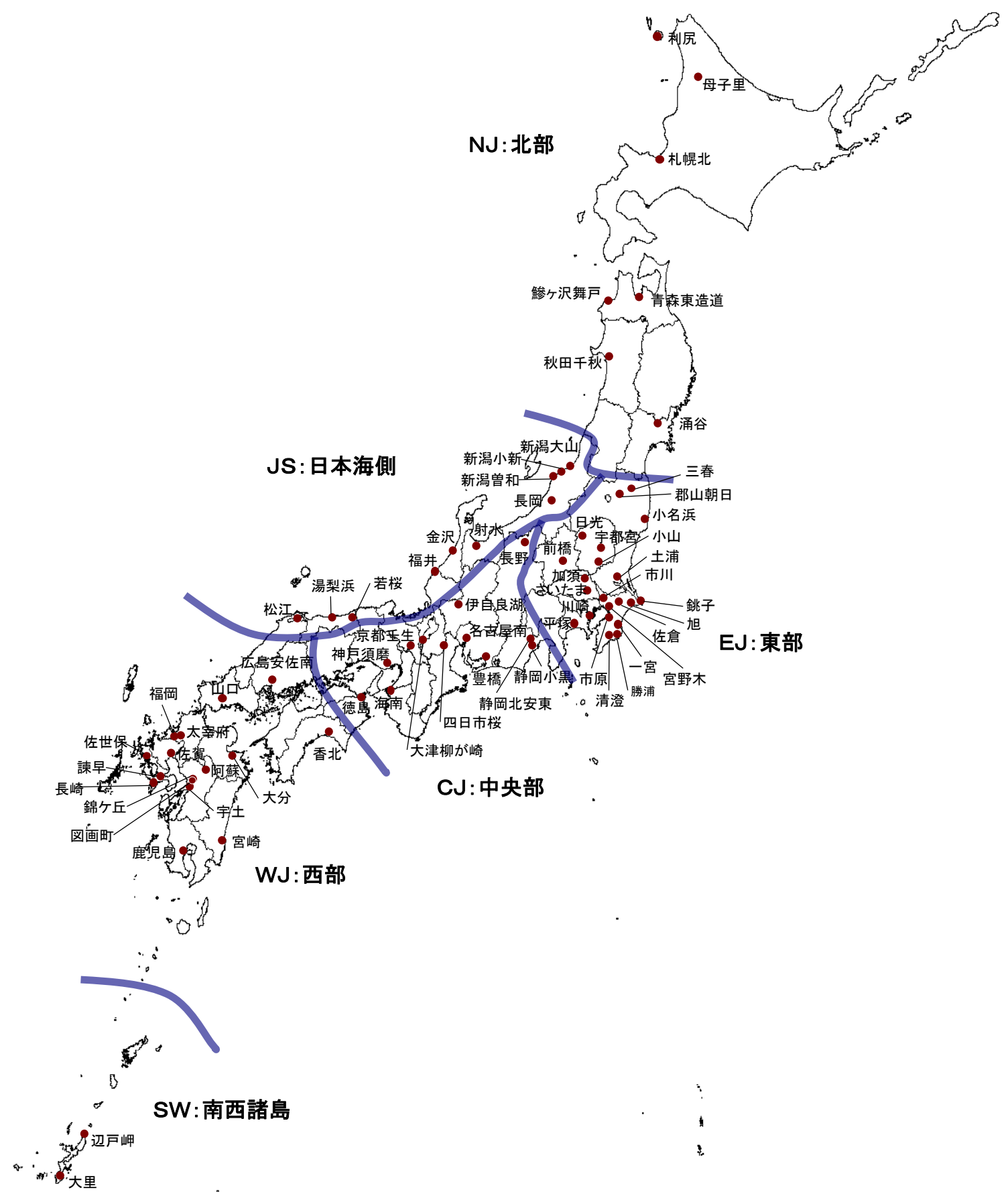

図4.2.1 地域区分

\section{4. $2 \mathrm{pH}$, ECおよびイオン成分濃度}

ここでは，2015年度の湿性沈着調査における $\mathrm{pH} ， \mathrm{EC}$ よびイオン成分濃度について報告する。

解析対象は，4.1.1で示したとおり，完全度（測定期間 の適合度を含む）が，月間データで60％以上，年間デー タで $80 \%$ 以上の地点のデータを有効とした。なお, 試料 採取時にオーバーフローがあり，降水量の算出ができな い試料については，近接の気象観測所等の降水量データ を採用した。

\section{2.1 降水量および酸性成分濃度による地域区分} 地域毎の特徵を把握するために，全国に分布する調査 地点を,「北部（NJ : Northern Japan area）」「日本海 側（JS : Japan Sea area）」「東部（EJ : Eastern Japan area）」「中央部（CJ : Central Japan area）」「西部

(WJ : Western Japan area)」および「南西諸島 (SW : Southwest Islands area)」の6つの地域区分に分類した。 地点毎の地域区分を，図4.2.1および表4.2.1に示す。な お, 地域区分の設定方法等については，既報1)を参照頂き たい。 
表4.2.1 湿性イオン成分等の地点別年加重平均濃度

\begin{tabular}{|c|c|c|c|c|c|c|c|c|c|c|c|c|c|c|c|c|c|c|}
\hline \multirow[t]{2}{*}{ 地点名 } & \multirow{2}{*}{$\begin{array}{c}\text { 地域 } \\
\text { 区分 }\end{array}$} & \multicolumn{3}{|c|}{ 排出量 $\left(\mathrm{t} \mathrm{km}^{-2} \mathrm{y}^{-1}\right)$} & & $\mathrm{pH}$ & EC & $\mathrm{SO}_{4}{ }^{2-}$ & nss $-\mathrm{SO}_{4}{ }^{2-}$ & $\mathrm{NO}_{3}^{-}$ & $\mathrm{Cl}^{-}$ & $\mathrm{NH}_{4}^{+}$ & $\mathrm{Na}^{+}$ & $\mathrm{K}^{+}$ & $\mathrm{Ca}^{2+}$ & $\mathrm{nss}^{-\mathrm{Ca}^{2+}}$ & $\mathrm{Mg}^{2+}$ & $\mathrm{H}^{+}$ \\
\hline & & $\mathrm{SO}_{2}$ & $\mathrm{NO}_{x}$ & $\mathrm{NH}_{3}$ & & & $\left(\mathrm{mS} \mathrm{m}^{-1}\right)$ & & & & & & $\left.\mathrm{mol} \mathrm{L}^{-1}\right)$ & & & & & \\
\hline 利尻 & $\mathrm{NJ}$ & 1.27 & 0.51 & 0.02 & 829 & 4.77 & 4.24 & 22.2 & 10.1 & 12.5 & 232.4 & 14.4 & 199.4 & 5.2 & 7.9 & 3.5 & 23.0 & 16.9 \\
\hline 母子里 & $\mathrm{NJ}$ & 0.12 & 0.76 & 0.49 & (1497) & $(4.81)$ & (2.95) & (17.1) & $(10.1)$ & (15.4) & (135.3) & (15.8) & (115.2) & (6.5) & (8.5) & (5.9) & (13.8) & (15.6) \\
\hline 札幌北 & $\mathrm{NJ}$ & 5.18 & 25.61 & 1.07 & 1157 & 4.80 & 3.13 & 17.0 & 9.1 & 12.0 & 153.4 & 15.8 & 130.7 & 3.6 & 6.0 & 3.0 & 14.7 & 16.0 \\
\hline 青森東造道 & $\mathrm{NJ}$ & 1.18 & 3.59 & 0.44 & 1011 & 5.05 & 4.25 & 27.8 & 14.8 & 20.1 & 234.2 & 23.2 & 214.0 & 5.7 & 10.0 & 5.2 & 23.8 & 9.0 \\
\hline 鰺ヶ沢舞戸 & $\mathrm{NJ}$ & 0.20 & 1.15 & 0.51 & 856 & 5.15 & 5.61 & 31.7 & 11.8 & 17.8 & 359.2 & 19.1 & 327.5 & 8.0 & 12.8 & 5.4 & 35.6 & 7.1 \\
\hline 涌谷 & $\mathrm{NJ}$ & 1.83 & 5.75 & 2.45 & 964 & 4.90 & 1.10 & 9.7 & 8.8 & 11.7 & 19.1 & 13.0 & 15.7 & 0.7 & 2.1 & 1.8 & 1.9 & 12.5 \\
\hline 秋田千秋 & $\mathrm{NJ}$ & 4.37 & 6.14 & 0.53 & 1444 & 4.85 & 3.06 & 22.9 & 16.0 & 20.5 & 139.0 & 27.3 & 114.4 & 3.6 & 6.7 & 4.1 & 13.5 & 14.0 \\
\hline 郡山朝日 & EJ & 1.32 & 6.08 & 1.37 & (483) & (4.8) & $(1.05)$ & (11.2) & $(11.0)$ & (13.8) & $(6.0)$ & (19.3) & (3.8) & $(0.6)$ & (2.5) & (2.4) & (1.0) & (15.8) \\
\hline 三春 & EJ & 1.31 & 6.42 & 1.48 & (255) & (5.13) & $(0.75)$ & $(7.4)$ & $(6.8)$ & (10.9) & (11.6) & $(8.0)$ & $(9.8)$ & $(0.8)$ & $(4.7)$ & $(4.5)$ & (1.6) & (7.4) \\
\hline 小名浜 & EJ & 13.81 & 16.92 & 0.99 & 1039 & 4.77 & 1.60 & 12.7 & 10.4 & 9.4 & 42.2 & 12.1 & 36.6 & 0.7 & 2.0 & 1.2 & 3.2 & 16.8 \\
\hline 新潟曽和 & JS & 2.60 & 9.49 & 1.28 & 1440 & 4.62 & 4.18 & 25.3 & 15.0 & 19.6 & 197.0 & 19.2 & 169.4 & 4.2 & 6.7 & 2.9 & 19.8 & 24.1 \\
\hline 長岡 & JS & 2.88 & 10.93 & 2.79 & 2277 & 4.65 & 4.13 & 26.8 & 16.7 & 20.6 & 192.2 & 22.1 & 166.5 & 4.3 & 6.9 & 3.1 & 19.5 & 22.2 \\
\hline 新潟大山 & JS & 2.75 & 12.68 & 1.74 & 1156 & 4.87 & 3.62 & 26.9 & 17.8 & 21.6 & 166.7 & 28.5 & 150.4 & 4.6 & 10.3 & 6.9 & 17.6 & 13.3 \\
\hline 新潟小新 & JS & 2.64 & 9.73 & 1.66 & 1510 & 4.69 & 4.26 & 26.6 & 15.7 & 20.1 & 200.0 & 21.6 & 179.4 & 4.9 & 7.1 & 3.1 & 20.8 & 20.6 \\
\hline 日光 & EJ & 2.49 & 18.24 & 3.51 & (2089) & $(4.97)$ & $(0.84)$ & (8.5) & (8.3) & (8.2) & (5.1) & (8.4) & (3.4) & (1.1) & (2.1) & (2.0) & $(0.6)$ & (10.6) \\
\hline 宇都宮 & EJ & 2.88 & 10.93 & 2.79 & 1846 & 4.89 & 1.38 & 14.3 & 13.6 & 21.4 & 14.6 & 27.3 & 11.5 & 0.9 & 3.4 & 3.1 & 1.7 & 12.8 \\
\hline 小山 & EJ & 8.63 & 59.68 & 4.64 & 1352 & 5.09 & 1.16 & 12.1 & 11.2 & 20.0 & 17.5 & 29.9 & 15.6 & 1.1 & 4.2 & 3.9 & 2.4 & 8.2 \\
\hline 加須 & EJ & 2.49 & 18.24 & 3.51 & 1389 & 4.94 & 1.24 & 11.2 & 10.6 & 21.6 & 14.1 & 20.8 & 9.8 & 1.4 & 6.6 & 6.4 & 2.0 & 11.4 \\
\hline さいたま & EJ & 7.46 & 48.21 & 5.19 & 1506 & 4.84 & 1.26 & 9.9 & 9.0 & 18.5 & 17.7 & 21.0 & 14.6 & 0.5 & 2.7 & 2.4 & 2.1 & 14.4 \\
\hline 土浦 & EJ & 1.44 & 7.73 & 3.20 & 1345 & 5.07 & 1.24 & 10.4 & 9.0 & 15.3 & 24.1 & 16.6 & 23.0 & 2.6 & 3.6 & 3.1 & 2.6 & 8.5 \\
\hline 前橋 & EJ & 4.13 & 12.96 & 7.55 & (1191) & (4.97) & (1.4) & (13.6) & (13.1) & (24.1) & (11.1) & (39) & $(7.2)$ & $(0.5)$ & (2.9) & $(2.7)$ & (1.3) & (10.7) \\
\hline 市川 & EJ & 8.63 & 59.68 & 4.64 & 1515 & 4.88 & 1.24 & 12.1 & 10.7 & 14.1 & 31.5 & 15.2 & 24.1 & 0.2 & 2.2 & 1.7 & 3.3 & 13.2 \\
\hline 市原 & EJ & 13.96 & 44.28 & 3.14 & 1654 & 4.85 & 1.28 & 17.2 & 15.8 & 11.2 & 29.4 & 15.9 & 21.6 & 0.6 & 5.5 & 5.0 & 3.4 & 14.0 \\
\hline 銚子 & EJ & 10.17 & 8.98 & 3.92 & 1664 & 5.51 & 1.82 & 13.2 & 8.0 & 9.5 & 101.4 & 23.8 & 85.3 & 0.3 & 2.4 & 0.7 & 7.7 & 3.1 \\
\hline 一宮 & EJ & 0.23 & 1.97 & 0.97 & 1776 & 5.07 & 1.61 & 11.0 & 6.5 & 7.3 & 87.7 & 8.8 & 73.7 & 0.4 & 2.2 & 0.8 & 7.2 & 8.6 \\
\hline 旭 & EJ & 16.98 & 74.45 & 3.11 & 1734 & 6.12 & 1.96 & 12.4 & 8.1 & 11.5 & 88.8 & 58.9 & 70.9 & 0.5 & 1.1 & 0.1 & 4.5 & 0.8 \\
\hline 佐倉 & EJ & 2.96 & 26.96 & 3.01 & 1494 & 4.89 & 1.09 & 11.2 & 10.1 & 11.7 & 25.4 & 11.2 & 19.2 & 0.4 & 2.4 & 2.0 & 2.7 & 12.7 \\
\hline 清澄 & EJ & 0.16 & 1.14 & 0.92 & 1880 & 5.21 & 1.22 & 11.2 & 8.3 & 7.1 & 57.3 & 5.2 & 47.6 & 1.0 & 6.0 & 4.9 & 4.7 & 6.2 \\
\hline 勝浦 & EJ & 0.16 & 1.06 & 0.66 & 2128 & 5.05 & 1.24 & 8.6 & 5.5 & 5.5 & 63.0 & 5.1 & 51.1 & 0.4 & 1.7 & 0.8 & 5.7 & 8.8 \\
\hline 宮野木 & EJ & 12.33 & 42.86 & 3.97 & 1302 & 5.59 & 0.78 & 7.7 & 6.9 & 7.2 & 18.6 & 8.9 & 13.6 & 1.2 & 5.1 & 4.8 & 3.0 & 2.6 \\
\hline 平塚 & EJ & 1.42 & 17.70 & 3.03 & 1636 & 5.12 & 1.49 & 12.1 & 9.4 & 17.0 & 51.3 & 22.5 & 43.6 & 1.2 & 4.3 & 3.3 & 4.8 & 7.7 \\
\hline 川崎 & EJ & 6.11 & 15.55 & 1.80 & 1492 & 5.32 & 1.39 & 15.0 & 13.1 & 12.2 & 38.8 & 22.3 & 32.7 & 2.8 & 5.9 & 5.1 & 4.7 & 4.8 \\
\hline 長野 & CJ & 1.35 & 4.76 & 0.61 & 775 & 4.83 & 1.05 & 10.4 & 10.0 & 10.8 & 7.6 & 13.5 & 5.2 & 0.6 & 2.0 & 1.9 & 1.2 & 14.8 \\
\hline 静岡小黒 & $\mathrm{CJ}$ & 3.29 & 10.23 & 1.42 & 2985 & 5.00 & 1.13 & 8.3 & 6.8 & 8.7 & 31.1 & 7.8 & 25.2 & 1.0 & 1.4 & 0.8 & 3.3 & 10.1 \\
\hline 静岡北安東 & CJ & 3.15 & 9.89 & 1.38 & 2847 & 5.00 & 1.06 & 6.7 & 5.5 & 7.8 & 28.7 & 6.2 & 19.2 & 0.8 & 1.6 & 1.2 & 2.5 & 10.1 \\
\hline 射水 & JS & 6.11 & 15.55 & 1.80 & 2072 & 4.70 & 3.40 & 22.1 & 14.3 & 19.6 & 144.2 & 21.8 & 128.8 & 3.5 & 5.5 & 2.6 & 14.5 & 20.0 \\
\hline 金沢 & JS & 2.74 & 6.93 & 1.12 & 2535 & 4.60 & 3.63 & 21.8 & 13.8 & 18.9 & 145.6 & 17.5 & 131.7 & 3.8 & 5.8 & 2.8 & 15.4 & 24.9 \\
\hline 福井 & JS & 2.41 & 7.77 & 0.80 & 1797 & 4.64 & 3.45 & 22.7 & 14.9 & 21.4 & 146.2 & 17.8 & 128.4 & 3.6 & 5.9 & 3.0 & 14.8 & 22.7 \\
\hline 伊自良湖 & CJ & 10.23 & 51.61 & 4.70 & 2747 & 4.77 & 1.26 & 10.1 & 9.3 & 14.4 & 16.1 & 12.0 & 12.8 & 0.5 & 1.6 & 1.3 & 1.6 & 17.2 \\
\hline 豊橋 & CJ & 2.36 & 10.81 & 4.18 & 2066 & 5.19 & 1.20 & 9.6 & 7.5 & 12.7 & 37.8 & 12.5 & 33.5 & 0.9 & 6.6 & 5.8 & 3.8 & 6.5 \\
\hline 名古屋南 & CJ & 10.23 & 51.61 & 4.70 & 1769 & 5.10 & 1.09 & 9.7 & 8.8 & 13.4 & 18.8 & 17.0 & 15.0 & 1.0 & 3.2 & 2.9 & 2.0 & 7.9 \\
\hline 四日市桜 & CJ & 4.10 & 17.71 & 2.31 & 2518 & 4.72 & 1.44 & 10.6 & 9.1 & 15.6 & 27.8 & 19.6 & 23.6 & 0.8 & 1.5 & 1.0 & 2.5 & 19.1 \\
\hline 大津柳が崎 & CJ & 3.92 & 17.74 & 1.34 & 1781 & 4.86 & 1.10 & 9.9 & 9.5 & 17.2 & 9.1 & 15.8 & 7.3 & 1.1 & 3.1 & 3.0 & 1.0 & 13.7 \\
\hline 京都壬生 & CJ & 3.96 & 17.81 & 1.65 & (1917) & $(4.96)$ & $(0.94)$ & (6.7) & $(6.3)$ & (10.7) & (6.5) & (10.4) & $(6.0)$ & $(0.9)$ & (2.2) & (2.1) & (1.2) & (11.0) \\
\hline 神戸須磨 & CJ & 10.20 & 30.41 & 1.05 & 1385 & 4.76 & 1.66 & 13.8 & 11.7 & 14.7 & 39.6 & 12.0 & 33.8 & 2.1 & 5.6 & 4.9 & 5.5 & 17.2 \\
\hline 海南 & CJ & 9.97 & 14.10 & 1.12 & 1728 & 4.81 & 1.22 & 11.4 & 10.1 & 10.3 & 26.7 & 10.1 & 21.5 & 0.8 & 2.8 & 2.3 & 2.2 & 15.7 \\
\hline 若桜 & JS & 0.03 & 0.50 & 0.30 & 2104 & 4.81 & 1.28 & 12.9 & 11.4 & 13.7 & 29.5 & 13.1 & 25.9 & 1.8 & 3.5 & 3.0 & 4.2 & 15.5 \\
\hline 湯梨浜 & JS & 0.25 & 1.30 & 0.86 & 1671 & 4.67 & 3.12 & 21.7 & 14.1 & 18.8 & 143.2 & 16.8 & 125.4 & 4.0 & 5.6 & 2.8 & 14.5 & 21.5 \\
\hline 松江 & JS & 0.46 & 2.49 & 0.56 & 1781 & 4.64 & 3.11 & 19.7 & 13.4 & 22.5 & 120.0 & 17.3 & 103.9 & 2.8 & 6.2 & 3.8 & 12.8 & 23.1 \\
\hline 広島安佐南 & WJ & 3.35 & 12.32 & 1.04 & 1257 & 4.73 & 1.35 & 12.1 & 11.1 & 14.1 & 17.5 & 10.4 & 15.3 & 0.7 & 3.2 & 2.9 & 2.1 & 18.6 \\
\hline 山口 & WJ & 2.28 & 5.84 & 0.63 & 1984 & 4.65 & 1.94 & 16.3 & 13.7 & 15.2 & 48.3 & 12.9 & 44.0 & 2.0 & 4.4 & 3.4 & 5.5 & 22.3 \\
\hline 德島 & CJ & 2.04 & 8.03 & 1.76 & 2030 & 4.91 & 1.81 & 10.9 & 6.7 & 9.7 & 79.9 & 9.7 & 68.9 & 2.0 & 3.5 & 1.9 & 7.9 & 12.2 \\
\hline 香北 & WJ & 0.04 & 0.46 & 0.18 & 2877 & 4.96 & 0.91 & 6.8 & 6.1 & 5.5 & 15.3 & 4.1 & 12.4 & 0.7 & 5.3 & 5.0 & 1.7 & 10.4 \\
\hline 太宰府 & WJ & 3.94 & 21.34 & 1.90 & 1856 & 4.63 & 2.31 & 20.4 & 17.4 & 19.0 & 56.8 & 18.7 & 49.4 & 1.9 & 5.3 & 4.2 & 6.3 & 23.7 \\
\hline 福岡 & WJ & 2.43 & 14.89 & 1.38 & 2707 & 4.65 & 2.51 & 18.8 & 14.0 & 16.8 & 92.6 & 16.9 & 78.9 & 2.7 & 4.5 & 2.7 & 9.4 & 22.5 \\
\hline 佐賀 & WJ & 2.50 & 6.92 & 1.63 & 2007 & 4.65 & 1.49 & 13.9 & 12.7 & 11.0 & 23.5 & 12.8 & 20.0 & 1.0 & 3.3 & 2.9 & 2.5 & 22.4 \\
\hline 諫早 & WJ & 5.88 & 7.58 & 1.30 & 2387 & 4.69 & 1.50 & 13.6 & 12.2 & 10.0 & 27.1 & 13.2 & 22.9 & 0.7 & 2.8 & 2.3 & 3.4 & 20.5 \\
\hline 長崎 & WJ & 1.17 & 4.99 & 0.62 & 1767 & 4.87 & 1.11 & 10.7 & 9.3 & 7.4 & 26.0 & 10.0 & 22.6 & 0.7 & 1.8 & 1.3 & 2.9 & 13.4 \\
\hline 佐世保 & WJ & 4.30 & 8.39 & 1.37 & 2052 & 4.70 & 2.07 & 18.1 & 15.2 & 15.3 & 65.8 & 11.2 & 48.4 & 2.0 & 7.9 & 6.8 & 9.4 & 19.7 \\
\hline 阿蘇 & WJ & 0.30 & 1.33 & 1.72 & 2728 & 4.60 & 1.83 & 15.5 & 14.9 & 8.4 & 22.9 & 14.2 & 9.7 & 1.6 & 3.9 & 3.6 & 2.1 & 25.3 \\
\hline 宇土 & WJ & 2.07 & 8.38 & 1.47 & 2415 & 4.86 & 1.18 & 9.8 & 8.9 & 7.8 & 17.1 & 9.8 & 15.2 & 0.9 & 2.0 & 1.6 & 2.0 & 13.9 \\
\hline 錦ヶ丘 & WJ & 1.71 & 8.83 & 3.56 & 1865 & 4.88 & 1.02 & 9.9 & 9.4 & 11.2 & 10.8 & 10.2 & 8.3 & 0.8 & 2.4 & 2.3 & 1.4 & 13.1 \\
\hline 画図町 & WJ & 1.65 & 8.71 & 2.93 & (72) & (4.77) & (1.85) & $(24.6)$ & $(24.0)$ & (22.1) & $(13.6)$ & (35.5) & $(10.7)$ & (1.7) & $(8.7)$ & (8.4) & (2.8) & (17.1) \\
\hline 大分 & WJ & 15.09 & 19.72 & 1.30 & 1841 & 4.64 & 1.53 & 14.6 & 14.0 & 13.7 & 13.2 & 10.6 & 9.9 & 0.6 & 2.2 & 1.9 & 1.5 & 23.2 \\
\hline 宮崎 & WJ & 0.56 & 3.25 & 1.14 & 3551 & 4.85 & 1.46 & 12.8 & 10.7 & 10.0 & 40.3 & 11.3 & 34.8 & 1.0 & 2.2 & 1.4 & 4.5 & 14.3 \\
\hline 鹿児島 & WJ & 1.41 & 5.88 & 1.37 & 2801 & 4.64 & 2.34 & 18.3 & 14.6 & 8.0 & 76.8 & 11.4 & 61.9 & 1.4 & 4.9 & 3.5 & 6.7 & 22.7 \\
\hline 大里 & SW & 6.30 & 7.83 & 2.08 & (1649) & (5.5) & (3.89) & (21.7) & (8.9) & (11.5) & $(244.5)$ & (27.8) & $(210.7)$ & (9.2) & (13.8) & (9.1) & (25.4) & (3.2) \\
\hline 辺戸岬 & SW & 0.00 & 0.05 & 0.35 & 2067 & 5.08 & 5.56 & 25.8 & 5.9 & 7.4 & 388.6 & 11.2 & 328.1 & 7.6 & 8.7 & 1.4 & 37.5 & 8.3 \\
\hline 最 低 值 & & & & & 775 & 4.60 & 0.78 & 6.7 & 5.5 & 5.5 & 7.6 & 4.1 & 5.2 & 0.2 & 1.1 & 0.1 & 1.0 & 0.8 \\
\hline 最高 值 & & & & & 3551 & 6.12 & 5.61 & 31.7 & 17.8 & 22.5 & 388.6 & 58.9 & 328.1 & 8.0 & 12.8 & 6.9 & 37.5 & 25.3 \\
\hline 加重平均値 & & & & & 1836 & 4.82 & 1.97 & 14.7 & 11.0 & 13.3 & 70.8 & 15.3 & 60.2 & 1.8 & 4.2 & 2.9 & 7.1 & 15.1 \\
\hline
\end{tabular}

※降水量は、単純平均值最大值: 白抜き 最小值: 斜体 参考值: (括弧) 

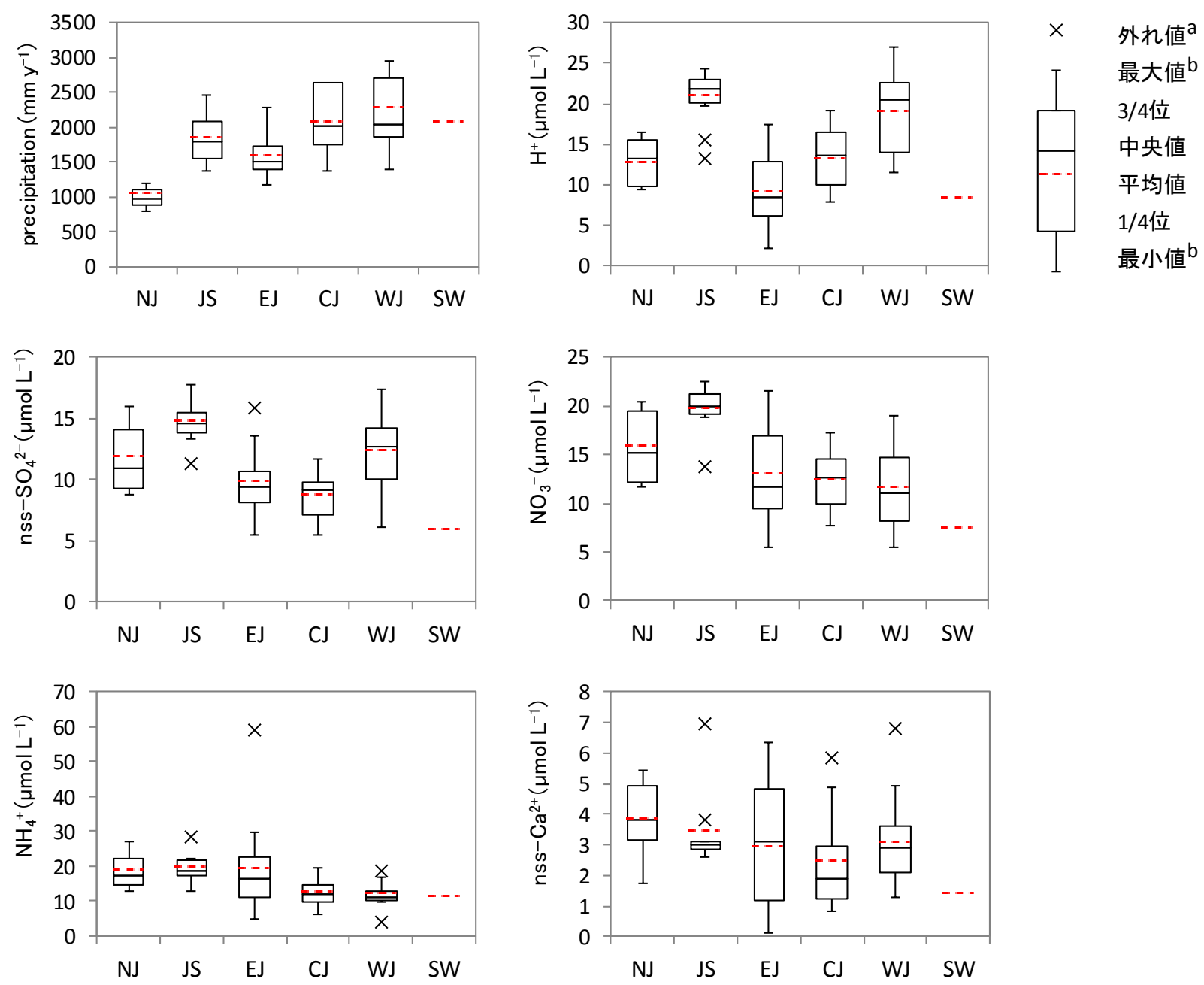

※SWは2015年度の解析対象が1地点のみであった。

$\mathrm{a}$ :箱の端からの距離が箱の長さの1.5倍以上 b:外れ值を除いた最大值又は最小値

\section{図4.2.2 主要イオン成分の年加重平均濃度の分布}

\section{4. $2.2 \mathrm{pH}, \mathrm{EC}$ よびイオン成分濃度の年加重平均 值}

2015年度の年間データが有効となった地点 (60地点)に おける, 降水量および湿性イオン成分濃度等の年加重平 均濃度を表4.2.1に示す。また, 主要イオン成分濃度につ いて，地域区分別に箱ひげ図を図4.2.2に示す。なお, “nss-”は「非海塩性 (nss : non sea salt)」を表し, 海 塩性イオン $\left(\mathrm{Na}^{+}\right.$をずて海塩由来として海塩組成比から 算出)を差し引いた残りであることを示している。

2015 年度の年間降水量は, 775 (長野) 3, $551 \mathrm{~mm}$ (宮崎) の範囲にあり, 単純平均は $1,836 \mathrm{~mm}$ であった。地域別で は，CJ，WJおよびSWで多く，NJで少ない傾向を示した。 年間平均pHは, 4.60 (金沢, 阿蘇) 6. 12 (旭)の範囲で, 加重平均は4.82であった。最高值を観測した旭は周辺に 大規模な畜産施設があり，その影響を受けたと考えられ る。 $\mathrm{H}^{+}$濃度としては, 加重平均は $15.1 \mu \mathrm{mol} \mathrm{L} \mathrm{L}^{-1}$ であり, JS およびWJで高く，NJおよびEJで低い傾向がみられた。

年間平均ECは, 0.78 (宮野木) 〜 $5.61 \mathrm{mS} \mathrm{m}^{-1}$ (鰺ヶ沢舞

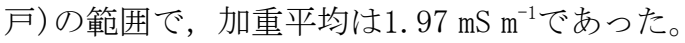
海塩粒子からの寄与を示す成分としては $\mathrm{Na}^{+} か ゙$ 用いら れる。年間平均 $\mathrm{Na}^{+}$濃度では，5.2(長野) $328.1 \mu \mathrm{mol} \mathrm{L} \mathrm{L}^{-1}$ (辺戸岬) の範囲で，加重平均は $60.2 \mu \mathrm{mol} \mathrm{L} \mathrm{L}^{-1}$ であった。

次に湿性沈着の污染状況を把握するのに重要なイオン 成分 $\left(\mathrm{nss}^{-} \mathrm{SO}_{4}{ }^{2-}, \mathrm{NO}_{3}{ }^{-}, \mathrm{NH}_{4}{ }^{+}\right.$およびnss- $\left.\mathrm{Ca}^{2+}\right)$ について記す。

降水の酸性化の原因となる酸性成分については, 次の とおりであった。

年間平均 $\mathrm{nss}^{-} \mathrm{SO}_{4}{ }^{2-}$ 濃度は, 5.5 (勝浦, 静岡北安東) $17.8 \mu \mathrm{mol} \mathrm{L}^{-1}$ (新潟大山) の範囲で, 加重平均は 11. $0 \mu \mathrm{mol} \mathrm{L} \mathrm{L}^{-1}$ であった。地域別では, JSおよびWJで高く， SWで低い傾向を示した。

年間平均 $\mathrm{NO}_{3}{ }^{-}$濃度は, 5.5 (勝浦，香北) 〜 $22.5 \mu \mathrm{mol} \mathrm{L}{ }^{-1}$ (松江)の範囲で, 加重平均は $13.3 \mu \mathrm{mol} \mathrm{L}$ であった。地域別では, JSで高く, SWで低い傾向を示した。

降水中の塩基性成分については, 次のとおりであった。 

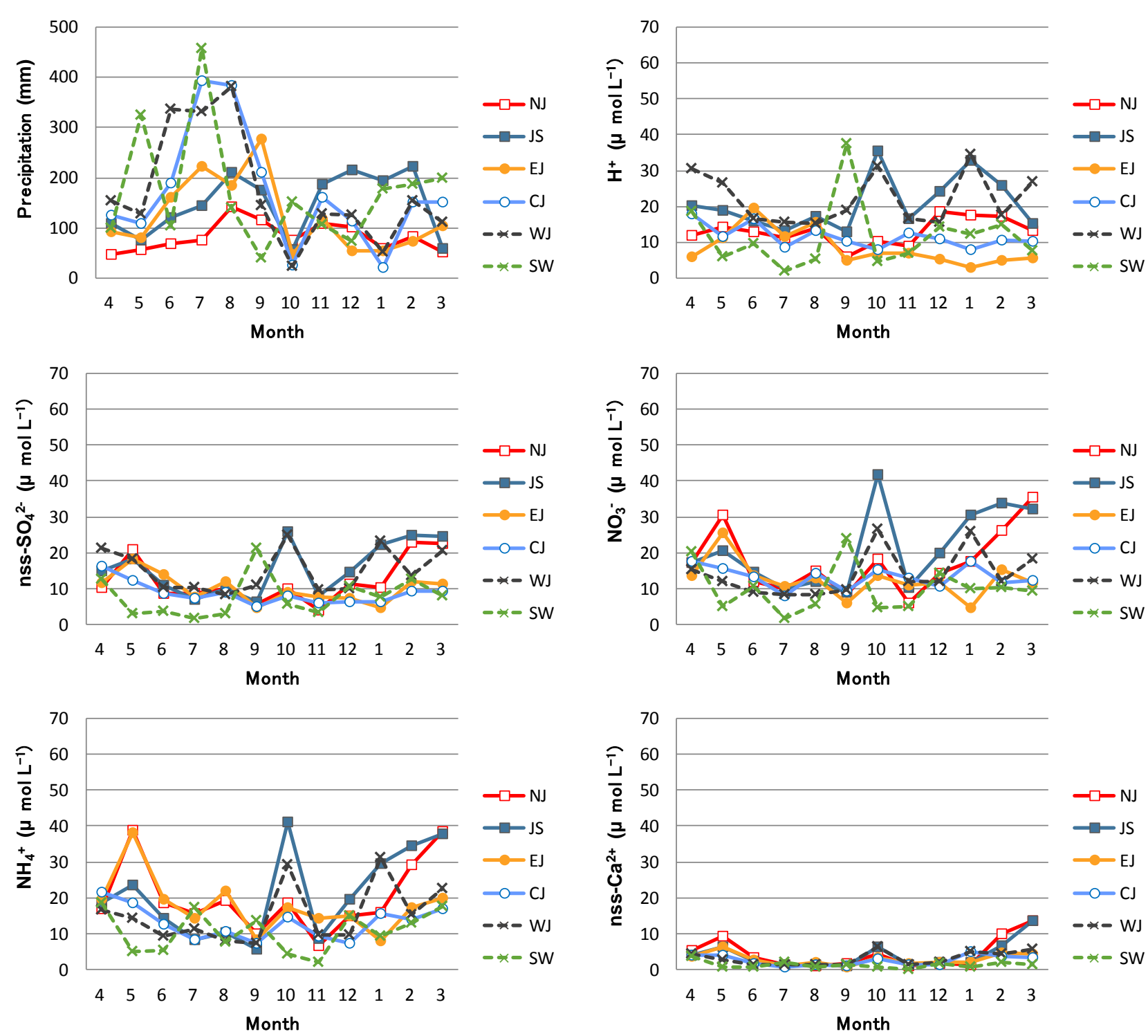

図4.2.3 イオン成分濃度の地域別季節変動（中央値）

年間平均 $\mathrm{NH}_{4}{ }^{+}$濃度は, 4.1 (香北) 〜 $58.9 \mu \mathrm{mol} \mathrm{L}{ }^{-1}$ (旭)の範 囲で, 加重平均は $15.3 \mu \mathrm{mol} \mathrm{L} \mathrm{L}^{-1}$ であった。地域別では, NJで高く, SWで低い傾向を示した。

年間平均 $\mathrm{nss}^{-} \mathrm{Ca}^{2+}$ 濃度は, 0.1 (旭) $~ 6.9 \mu \mathrm{mol} \mathrm{L} \mathrm{L}^{-1}$ (新潟 大山）の範囲で, 加重平均は $2.9 \mu \mathrm{mol} \mathrm{L}-1$ であった。地域 別では，NJで高く，SWで低い傾向を示した。

\section{2. 3 pHおよびイオン成分濃度の季節変動}

湿性沈着による污染実態を把握するのに重要と考えら れる項目について, 2015年度の季節変動を地域区分別に 図4.2.3に示す。地域区分別の月間代表值としては, 地域 区分内での中央值を採用した。なお，中央值を採用した 理由は, データ数が比較的少ないため, 平均值を採用す ると1つの外れ值に引きずられて, 代表性がそしくなると 考えられるためである。

降水量は, EJ, CJ, WJおよびSWでは夏季に, NJでは秋 季に, JSでは冬季に多い傾向を示した。
H濃度は，NJおよびJSでは冬季に，EJでは夏季に，CJ およびWJでは春季に, SWでは秋季に高い傾向が見られた。 $\mathrm{nsS}^{-} \mathrm{SO}_{4}{ }^{2-}$ 濃度は, $\mathrm{NJ}, \mathrm{EJ}, \mathrm{CJ}$ およびWJでは春季に, JS およびSWでは冬季に高い傾向が見られた。

$\mathrm{NO}_{3}$-濃度は，NJ，EJおよびCJでは春季に，JS，WJおよ びSWでは冬季に高い傾向が見られた。

$\mathrm{NH}_{4}^{+}$濃度はNJ, EJ, CJおよびSWでは春季に, JSおよび WJでは冬季および春季に高い傾向が見られた。

$\mathrm{nss}^{-} \mathrm{Ca}^{2+}$ 濃度は, 他のイオン成分に比較して, 年間を 通し, 低い值で推移していたが, 春季に高濃度となる傾 向が見られた。

濃度の季節変動において特徵的なことの一つは, JS およびWJでは, 春季および冬季に, $\mathrm{H}^{+}, \mathrm{nss}^{-} \mathrm{SO}_{4}{ }^{2-}$ 濃度が 高い傾向がみられたことである。地理的要因や春季およ び冬季の風向等を考慮すると, 大陸からの污染物質の移 流が示唆された。なお，2005年度までは，この大陸から 
の越境大気污染を示唆する傾向は，JSで顕著であった ${ }^{1,3,4)}$ が，2006年度にはその傾向がWJでも確認され5)，2007〜 2015年度も引き続き同様の傾向がみられた ${ }^{6-12)}$ 。

\section{3 イオン成分湿性沈着量}

イオン成分の年間沈着量や月間沈着量の, 地点間や地 域間の比較を行った。解析対象は 4.2 と同様に扱った。

\section{3.1 年間沈着量}

2015年度の年間データが有効となった 60 地点における 年間降水量および主要イオン成分の年間沈着量について, 表4.3.1に要約した。また, 図4.3.1には主要イオン成分 の沈着量について，地域区分別に箱ひげ図を示した。な お，年間沈着量は，年平均濃度に年間降水量を掛け合わ せることにより算出した。

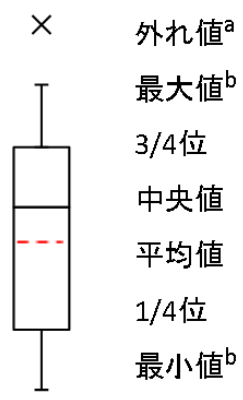

$\mathrm{a}:$ 箱の端からの距離が箱の長さの 1.5 倍以上 b:外れ値を除いた最大値又は最小値
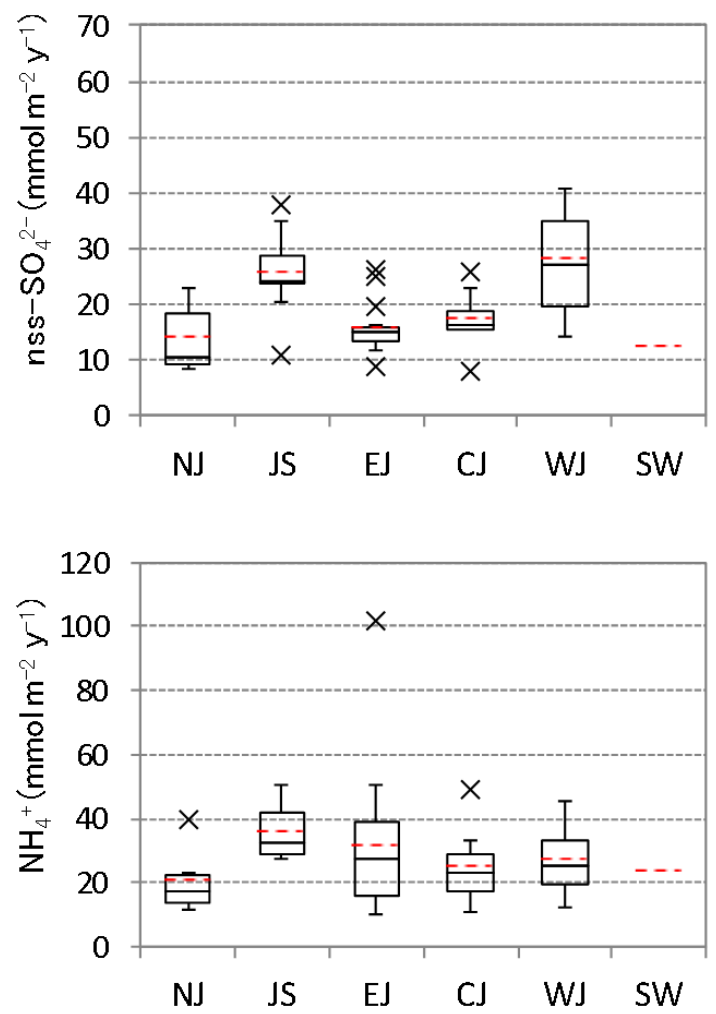

※SWは2015年度の解析対象が1地点のみであった。
表4.3.1 降水量と主要イオン成分の年間沈着量

\begin{tabular}{|c|c|c|c|c|}
\hline 項目 & （単位） & 中央値 & $\begin{array}{l}\text { 最小値 } \\
\text { 最大值 }\end{array}$ & $\begin{array}{l}\text { （地点名） } \\
\text { (地点名) }\end{array}$ \\
\hline 降水量 & $\left(m m y^{-1}\right)$ & 1772 & $\begin{array}{r}775 \\
3551 \\
\end{array}$ & $\begin{array}{l}\text { (長野) } \\
\text { (宮崎) }\end{array}$ \\
\hline $\mathrm{nss}^{-\mathrm{SO}_{4}}{ }^{2-}$ & $\left(\mathrm{mmol} \mathrm{m} \mathrm{m}^{-2} \mathrm{y}^{-1}\right)$ & 17.5 & $\begin{array}{r}7.8 \\
40.9 \\
\end{array}$ & $\begin{array}{l}\text { (長野) } \\
\text { (鹿児島) }\end{array}$ \\
\hline $\mathrm{NO}_{3}^{-}$ & $(I I)$ & 22.7 & $\begin{array}{r}8.4 \\
47.9 \\
\end{array}$ & $\begin{array}{l}\text { (長野) } \\
\text { (金沢) } \\
\end{array}$ \\
\hline $\mathrm{NH}_{4}^{+}$ & $(I I)$ & 26.0 & $\begin{array}{r}9.8 \\
102.1 \\
\end{array}$ & $\begin{array}{l}\text { (清澄) } \\
\text { (旭) }\end{array}$ \\
\hline $\mathrm{nss}^{-} \mathrm{Ca}^{2+}$ & $(\prime \prime)$ & 4.9 & $\begin{array}{r}0.2 \\
14.3 \\
\end{array}$ & $\begin{array}{l}\text { (旭) } \\
\text { (香北) }\end{array}$ \\
\hline $\mathrm{H}^{+}$ & $(I I)$ & 23.7 & $\begin{array}{r}1.3 \\
69.1\end{array}$ & $\begin{array}{l}\text { （旭） } \\
\text { (阿蘇) }\end{array}$ \\
\hline
\end{tabular}
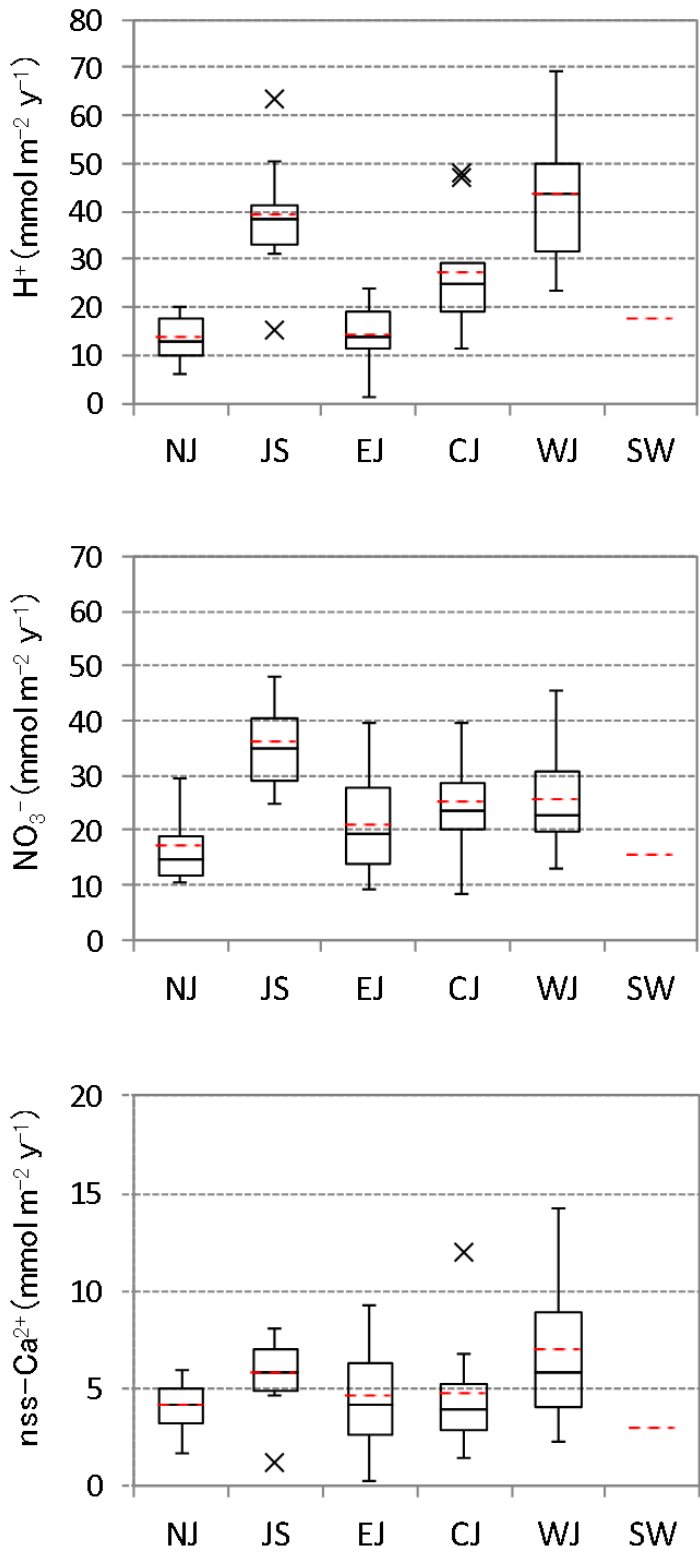

図4.3.1 主要イオン成分年間沈着量および降水量の分布 

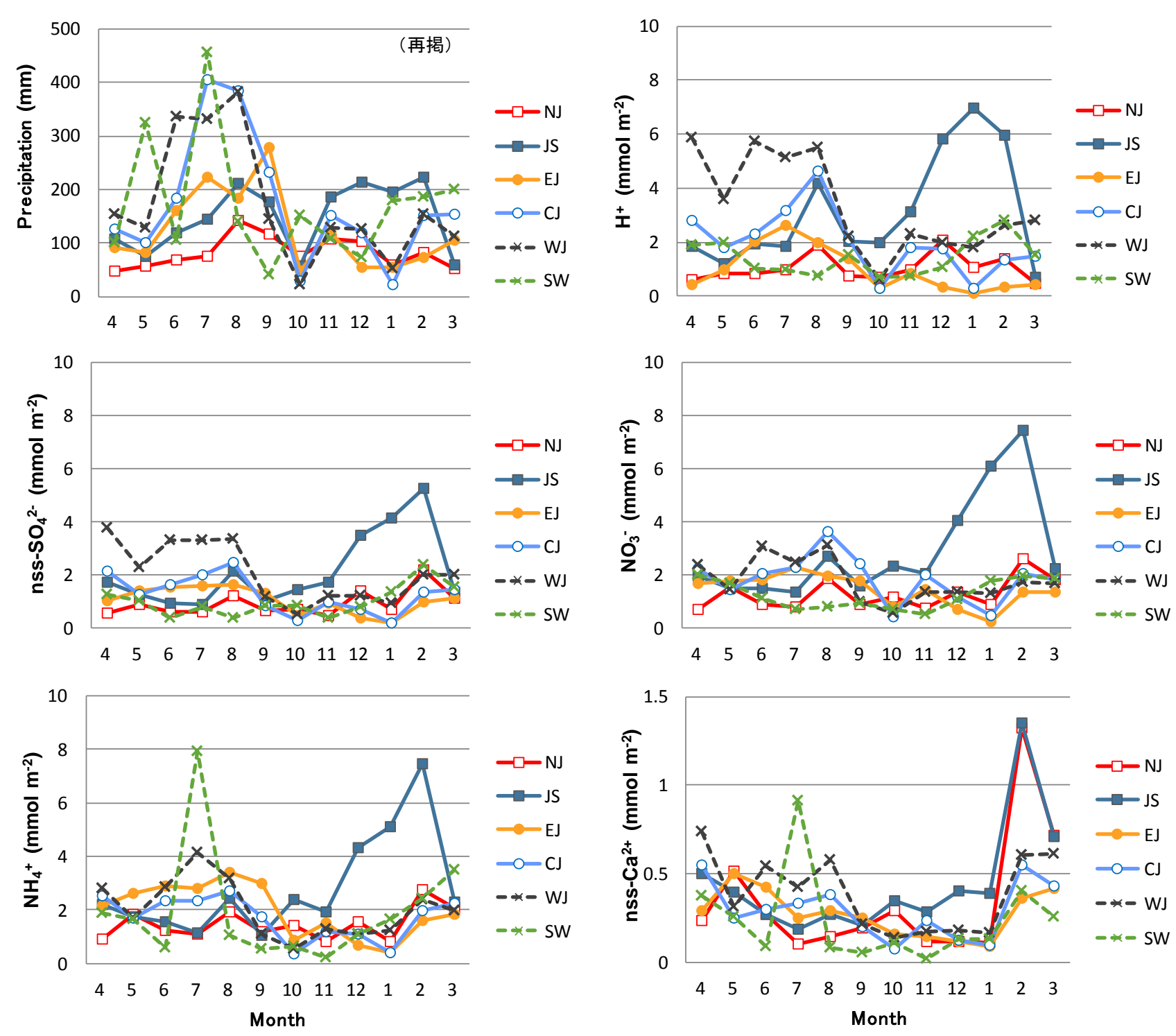

図4.3. 2 イオン成分沈着量の地域別季節変動（中央値）

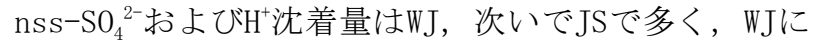
おける中央值はそれぞれ27.1および43. $9 \mathrm{mmol} \mathrm{m}^{-2} \mathrm{y}^{-1}$ であ った。

$\mathrm{NO}_{3}^{-}$沈着量はJSで多い傾向を示し, 中央值は $34.9 \mathrm{mmol} \mathrm{m} \mathrm{y}^{-1}$, それ以外の地域では中央值が 14.6 $22.9 \mathrm{mmol} \mathrm{m}^{-2} \mathrm{y}^{-1}$ の間であった。

$\mathrm{NH}_{4}^{+}$沈着量はJSで多く中央値は $32.2 \mathrm{mmol} \mathrm{m}^{-2} \mathrm{y}^{-1}$, それ以 外の地域では中央值が $17.3 \sim 27.6 \mathrm{mmol} \mathrm{m}^{-2} \mathrm{y}^{-1}$ の間であっ た。

$\mathrm{nsS}^{-} \mathrm{Ca}^{2+}$ 沈着量は, 他の非海塩成分と比較して沈着量が $1 / 4$ 程度少なく, 中央值が3. 9 $5.8 \mathrm{mmol} \mathrm{m}^{-2} \mathrm{y}^{-1}$ の間であっ た。

\section{3.2 沈着量の季節変動}

地域別の降水量 (再掲) および主要イオン成分沈着量 の季節変動を図4.3.2 に示す。4.2.3章と同様に, 月間代 表值として中央值を採用した。

$\mathrm{H}^{+}$沈着量は, JSでは12月から2月に最も多い傾向であり，
次いで8月に多く，WJでは4月から8月にかけて，CJでは8 月に多かった。同様の傾向がnss- $\mathrm{SO}_{4}{ }^{2-}$ 沈着量でみられた。 $\mathrm{NO}_{3}$-沈着量はJSで12月〜2月に多い傾向であり, $\mathrm{NH}_{4}^{+}$沈 着量でも同様の傾向が見られた。また $\mathrm{NH}_{4}^{+}$沈着量はEJでは 4月〜9月に多い傾向であり, WJ と SWでは7月に多くなった。 $\mathrm{nsS}^{-} \mathrm{Ca}^{2+}$ 沈着量は，JSおよびNJで2月に最も多いく，そ の他の地域では 9 月〜 月以外の月に最多となる傾向であ つた。

\section{4 年平均濃度と年間沈着量の経年変動}

第5次酸性雨全国調査期間（6年間）の年平均濃度と年 間沈着量の地域間の比較を行った。解析対象は 4.2 と同様 に扱った。

\section{4.1 年平均濃度の経年変動}

地域別の降水量および主要イオン成分濃度の地域別経 年変動（2009～2015年度）を図4.4.1に示す。データは各 地域の年平均值の中央值を採用した。 

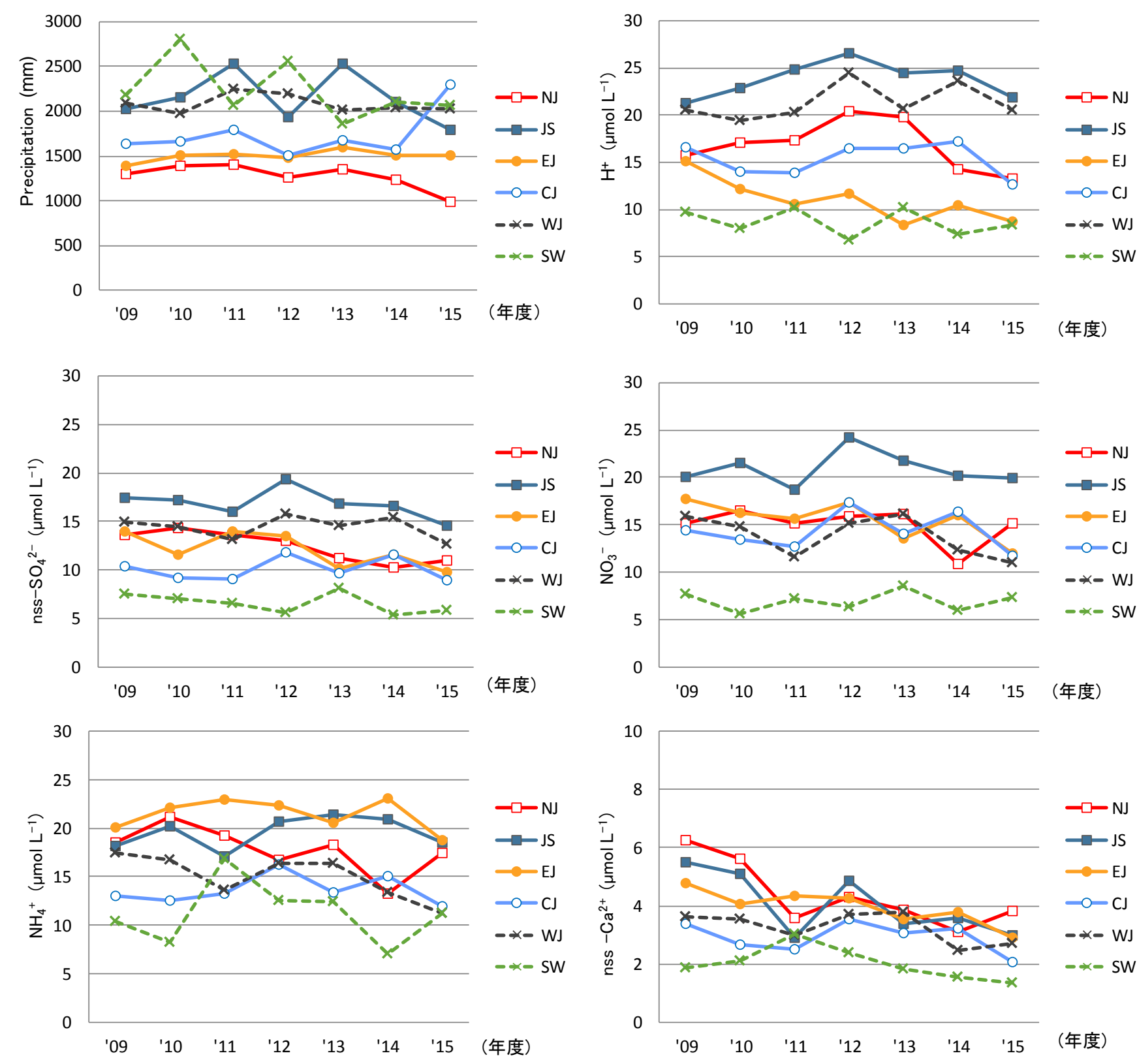

図4.4.1 イオン成分濃度の地域別経年変動（中央値）

降水量はJS, WJ, SWの3地域で多く, NJとEJで7年間を 通じて少なかった。7年間の地域別での最多降水量は $2158 \mathrm{~mm}$ （SW，2010年度）で, 最少降水量は988 mm（NJ, 2015年度）であった。

H濃度はJSで7年間を通じて一貫して最も高い傾向に あり, 続いてWJ, NJの順番に高濃度でSWが最も低かった。 $\mathrm{H}^{+}$濃度の最高值は26. $6 \mu \mathrm{mol} \mathrm{L} \mathrm{L}^{-1}$ (JS，2012年度）で, 最低 值は6. $8 \mu \mathrm{mol} \mathrm{L} \mathrm{L}^{-1}$ （SW，2012年度）であった。

$\mathrm{nsS}^{-} \mathrm{SO}_{4}{ }^{2-}$ 濃度および $\mathrm{NO}_{3}{ }^{-}$濃度も同様にJSが7年間を通じ て一貫して最も高い傾向にあり, SWが最も低い傾向がみ られた。 $\mathrm{nss}^{-} \mathrm{SO}_{4}{ }^{2-}$ 濃度の最高值は19. $3 \mu \mathrm{mol} \mathrm{L}{ }^{-1}$ (JS, 2012 年度) で, 最低值は5. $3 \mu \mathrm{mol} \mathrm{L} \mathrm{L}^{-1}$ (SW, 2014年度) であり, $\mathrm{NO}_{3}$-濃度の最高值は24. $2 \mu \mathrm{mol} \mathrm{L}{ }^{-1}$ （JS，2012年度）で, 最
低值は5. $6 \mu \mathrm{mol} \mathrm{L} \mathrm{L}^{-1}$ （SW，2010年度）であった。

$\mathrm{NH}_{4}^{+}$濃度はEJで高い傾向を示し, SWで低い傾向を示した。 $\mathrm{NH}_{4}^{+}$濃度の最高值は23. $1 \mu \mathrm{mol} \mathrm{L}{ }^{-1}$ （EJ，2014年度）で，最 低值は7. $0 \mu \mathrm{mol} \mathrm{L} \mathrm{L}^{-1}$ (SW，2014年度）であった。

$\mathrm{nss}^{-} \mathrm{Ca}^{2+}$ 濃度に関してはSWで低い傾向を示したが, その ほかの地域では大きな差はみられなかった。nss-Ca ${ }^{2+}$ 濃度 の最高值は6. $3 \mu \mathrm{mol} \mathrm{L} \mathrm{L}^{-1}$ (NJ，2009年度）で，最低值は $1.4 \mu \mathrm{mol} \mathrm{L} \mathrm{L}^{-1}$ （SW，2015年度）であった。

降水量, $\mathrm{H}^{+}, \mathrm{nss}^{-} \mathrm{SO}_{4}{ }^{2-}, \mathrm{NO}_{3}^{-}$および $\mathrm{NH}_{4}^{+}$濃度については7 年間を通じてほぼ横ばいの傾向を示したが, $\mathrm{nss}^{-} \mathrm{Ca}^{2+}$ 濃度 については，減少傾向がみられた。

\section{4.2 年間沈着量の経年変動}

地域別の降水量および主要イオン成分沈着量の地域別 

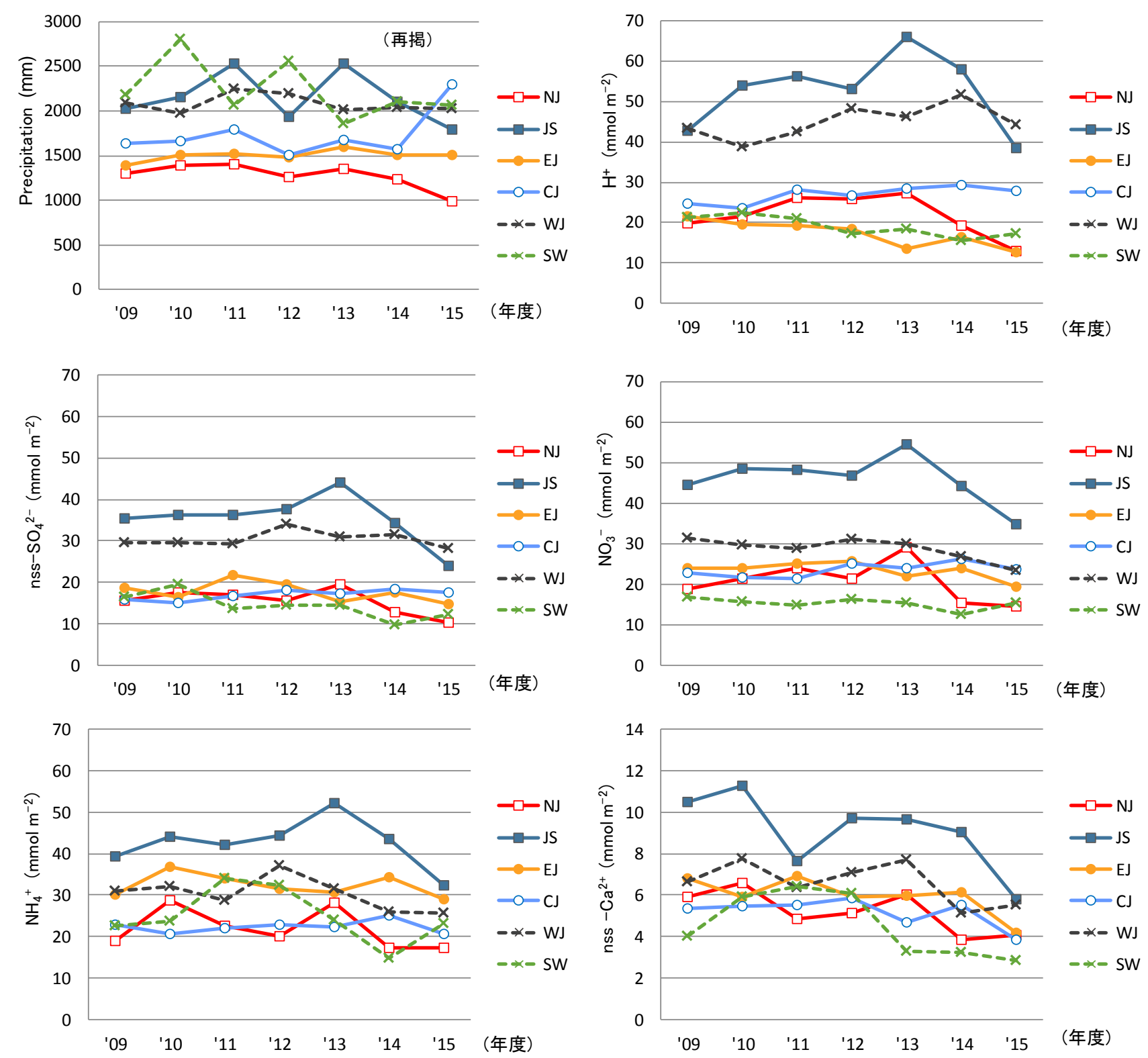

図4.4.2 イオン成分沈着量の地域別経年変動（中央值）

経年変動（2009～2015年度）を図4.4.2に示す。データ は各地域の年平均值の中央值を採用した。

2009 2014年度にかけて, 図に示した主要成分の沈着量 すべて $\left(\mathrm{H}^{+}, \mathrm{nss}^{-} \mathrm{SO}_{4}{ }^{2-}, \mathrm{NO}_{3}{ }^{-}, \mathrm{NH}_{4}{ }^{+}\right.$およひびnss- $\mathrm{Ca}^{2+}$ 沈着量 $)$ でJSが多く次にWJが多い傾向がみられた。2015年度には $\mathrm{H}^{+}, \mathrm{nss}^{-} \mathrm{SO}_{4}{ }^{2-}$ 沈着量でJSがWJより少なくなったが，降水 量の影響が大きいと考えられた。

7年間を通して $\mathrm{H}^{+}, \mathrm{nsS}^{-} \mathrm{SO}_{4}{ }^{2-}, \mathrm{NO}_{3}{ }^{-}$およよび $\mathrm{NH}_{4}{ }^{+}$沈着量につ いてJSを除く地域では, ほぼ横ばいもしくは微減傾向を 示したが，JSでは2013年度をピークに減少の傾向がみら れた。これは, 年平均濃度の中央値が2013年度から減少 傾向にあることに加え, 年平均降水量の中央值が減少傾 向であることに起因していると考えられた。また， $\mathrm{nss}^{-} \mathrm{Ca}^{2+}$ 沈着量については, 各地域とも年平均值の中央值
は減少傾向を示した。

\section{一 引用文献 -}

1）全国環境研協議会 : 第4次酸性雨全国調查報告書（平 成17年度），全国環境研会誌，32，78-152，2007

2）環境省地球環境局環境保全対策課, 酸性雨研究セン ター: 湿性沈着モニタリング手引き書 (第2版)，2001, http://www. env. go. jp/air/acidrain/man/wet_deposi /index. html

3）全国環境研協議会 : 第4次酸性雨全国調査報告書（平 成15年度），全国環境研会誌，30，58-135，2005

4）全国環境研協議会: 第4次酸性雨全国調査報告書 (平 成16年度），全国環境研会誌，31，118-186，2006

5）全国環境研協議会: 第4次酸性雨全国調査報告書 (平 
成18年度），全国環境研会誌，33，126-196，2008

6) 全国環境研協議会: 第4次酸性雨全国調査報告書 (平 成19年度），全国環境研会誌，34，193-223，2009

7) 全国環境研協議会: 第4次酸性雨全国調査報告書 (平 成20年度），全国環境研会誌，35，88-138，2010

8）全国環境研協議会 酸性雨広域大気污染調査研究部 会 : 第5次酸性雨全国調査報告書（平成21年度）, 全 国環境研会誌，36，106-146，2011

9）全国環境研協議会 酸性雨広域大気污染調査研究部 会 : 第5次酸性雨全国調査報告書 (平成22年度), 全国 環境研会誌，37，110-158，2012

10）全国環境研協議会 酸性雨広域大気污染調査研究部
会 : 第5次酸性雨全国調査報告書（平成23年度），全国 環境研会誌，38，84-126，2013

11）全国環境研協議会 酸性雨広域大気污染調査研究部 会 : 第5次酸性雨全国調査報告書（平成25年度），全国 環境研会誌，40，98-142，2015

12）全国環境研協議会 酸性雨広域大気污染調查研究部 会 : 第5次酸性雨全国調査報告書（平成26年度）, 全国 環境研会誌，41，3，2-37，2016

13）一般財団法人日本環境衛生センター アジア大気 污染研究センター：平成27年度酸性雨測定分析精度管 理調査結果報告書（国設酸性雨測定所），2016 


\section{5. 乾性沈着（フィルターパック法）}

2015年度のフィルターパック法 (以下, FP法)による乾 性沈着調查地点および地域区分を図5.1.1に示す。2015 年度は31地点で乾性沈着調査を実施した。地域区分は, 湿性沈着と同じく, 北部 [NJ], 日本海側 $[J S]$, 東部 [EJ], 中央部 $[\mathrm{CJ}]$, 西部 $[\mathrm{WJ}]$ および南西諸島 $[\mathrm{SW}]$ の 6 地域とした。 なお, 調査結果には国設局および他の学術機関との共 同研究データが含まれているが，データ確定を部会基準 （5.1に後述）で行ったため, 特に国設局については環境 省が公表したデータ1) と異なる場合がある。また, 成分名 に付してある (g) はガス状成分を，(p) は粒子状成分をそ れぞれ表す。

\section{1 データの確定}

\subsection{1 完全度および流量変動による判定}

FP法の有効データ数を表 5.1 .1 亿示す。データ確定にお いては, 完全度 (測定期間の適合度を含む)を指標として， 月データで $60 \%$ 以上，年データで $80 \%$ 以上の場合を有効デ 一タとし，それ以外を参考值として解析対象から除外し た。ただし，月データの完全度が $60 \%$ 未満でも，年データ が80\%以上であれば，年平均值は解析対象とした。また， サンプリングや測定に不具合があると考えられた場合や 実施要領に記載された方法に準拠していない場合も参考 值または欠測とした。

これまでの調查結果から，FP法は吸引流量の変動が大 きいと異常值になりやすいことがわかっている2)。

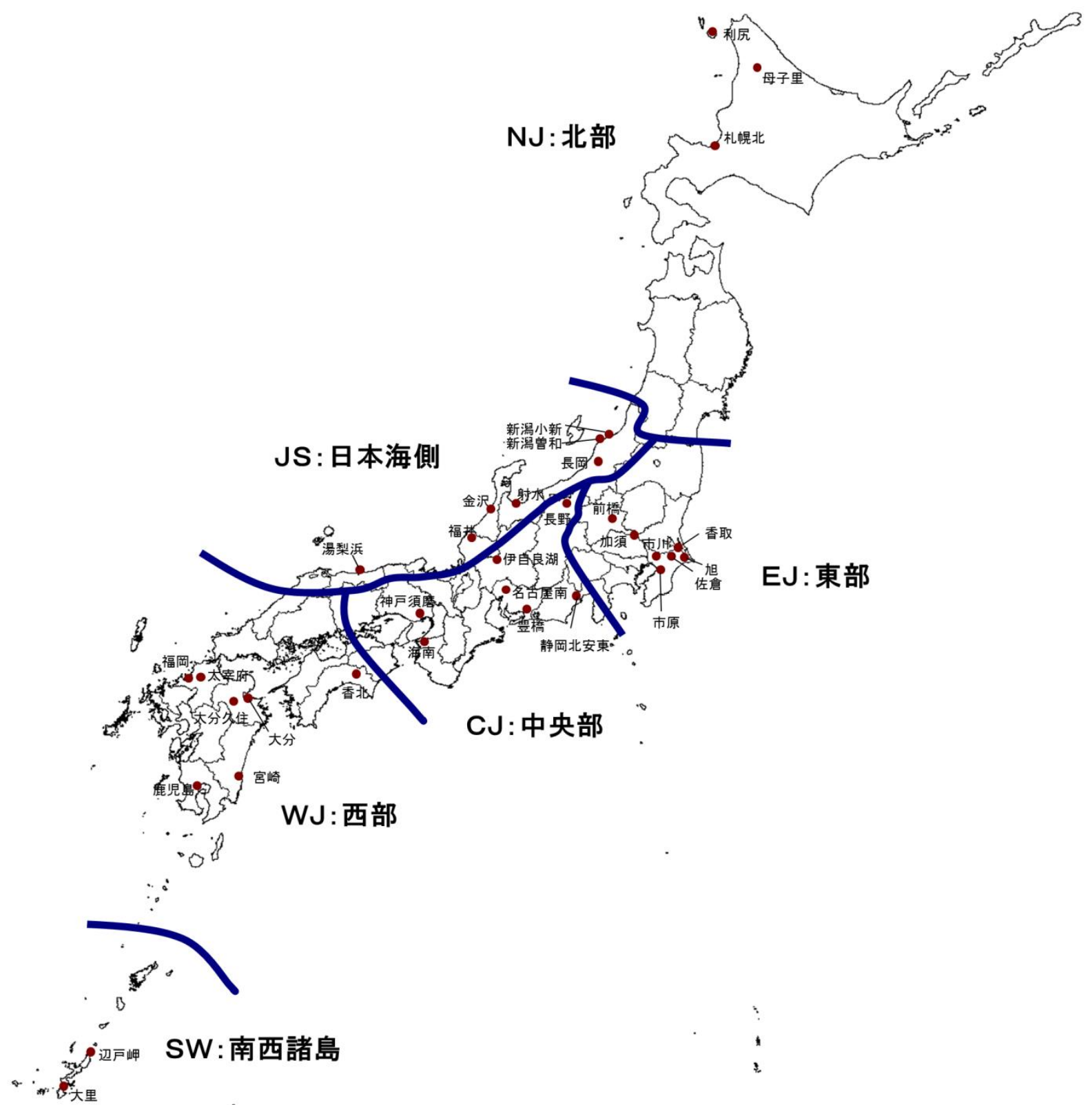

図5.1.1 FP法の調查地点（地域区分は表2.1.1のとおり） 
表5.1.1 FP法による調査結果の有効データ数

\begin{tabular}{|c|c|c|c|c|c|c|c|c|c|c|c|c|c|c|c|}
\hline \multirow[b]{2}{*}{ 成分 } & \multirow[b]{2}{*}{ 地点数 } & \multicolumn{7}{|c|}{ 月平均濃度 } & \multicolumn{7}{|c|}{ 年平均濃度 } \\
\hline & & 欠測数 & $\vec{\Gamma}-$ 数 & $\begin{array}{c}\text { 完全度 } \\
60 \% \text { 未満 }\end{array}$ & $\begin{array}{l}\text { 参の他 } \\
\text { 考考値 }\end{array}$ & 適合数 & $\begin{array}{c}\text { 定量下限 } \\
\text { 値未満 }\end{array}$ & $\begin{array}{l}\text { 有効データ } \\
\text { 割合 }(\%) \\
\end{array}$ & 欠測数 & データ数 & $\begin{array}{c}\text { 完全度 } \\
80 \% \text { 未満 }\end{array}$ & $\begin{array}{l}\text { 参の他 } \\
\text { 考值 }\end{array}$ & 適合数 & $\begin{array}{c}\text { 定量下限 } \\
\text { 值未满 }\end{array}$ & $\begin{array}{l}\text { 有効データ } \\
\text { 割合 }(\%) \\
\end{array}$ \\
\hline $\mathrm{HNO}_{3}(\mathrm{~g})$ & 31 & 3 & 369 & 16 & 1 & 352 & 47 & 95 & 0 & 31 & 1 & 0 & 30 & 3 & 97 \\
\hline $\mathrm{SO}_{2}(\mathrm{~g})$ & 31 & 3 & 369 & 16 & 1 & 352 & 4 & 95 & 0 & 31 & 1 & 0 & 30 & 0 & 97 \\
\hline $\mathrm{HCl}(\mathrm{g})$ & 31 & 3 & 369 & 16 & 1 & 352 & 4 & 95 & 0 & 31 & 1 & 0 & 30 & 0 & 97 \\
\hline $\mathrm{NH}_{3}(\mathrm{~g})$ & 31 & 3 & 369 & 16 & 1 & 352 & 0 & 95 & 0 & 31 & 1 & 0 & 30 & 0 & 97 \\
\hline $\mathrm{SO}_{4}{ }^{2-}(\mathrm{p})$ & 31 & 3 & 369 & 16 & 1 & 352 & 0 & 95 & 0 & 31 & 1 & 0 & 30 & 0 & 97 \\
\hline $\mathrm{NO}_{3}^{-}(\mathrm{p})$ & 31 & 3 & 369 & 16 & 1 & 352 & 0 & 95 & 0 & 31 & 1 & 0 & 30 & 0 & 97 \\
\hline $\mathrm{Cl}^{(}(\mathrm{p})$ & 31 & 3 & 369 & 16 & 1 & 352 & 7 & 95 & 0 & 31 & 1 & 0 & 30 & 0 & 97 \\
\hline $\mathrm{Na}^{+}(\mathrm{p})$ & 31 & 3 & 369 & 16 & 1 & 352 & 0 & 95 & 0 & 31 & 1 & 0 & 30 & 0 & 97 \\
\hline $\mathrm{K}^{+}(\mathrm{p})$ & 31 & 3 & 369 & 16 & 1 & 352 & 3 & 95 & 0 & 31 & 1 & 0 & 30 & 0 & 97 \\
\hline $\mathrm{Ca}^{2+}(\mathrm{p})$ & 31 & 3 & 369 & 16 & 1 & 352 & 0 & 95 & 0 & 31 & 1 & 0 & 30 & 0 & 97 \\
\hline $\mathrm{Mg}^{2+}(\mathrm{p})$ & 31 & 3 & 369 & 16 & 1 & 352 & 1 & 95 & 0 & 31 & 1 & 0 & 30 & 0 & 97 \\
\hline $\mathrm{NH}_{4}^{+}(\mathrm{p})$ & 31 & 3 & 369 & 16 & 1 & 352 & 0 & 95 & 0 & 31 & 1 & 0 & 30 & 0 & 97 \\
\hline
\end{tabular}

そのため, 設定流量の変更等の明確な理由がないにも 関わらず流量変動が大きかった場合(年間の平均流量と 標準偏差から算出した変動係数が30\%以上) は年間を通し て参考值としている。2015年度は，流量変動を理由とし て解析対象から除外された調查地点はなかった。

\section{1.2 定量下限値の設定}

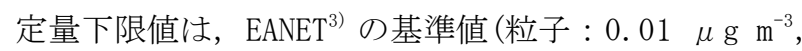
ガス：0.1 ppb)を用いた。吸引流量は $1 \mathrm{~L} \mathrm{~min}^{-1}$ を基準と し，X L min ${ }^{-1}$ の場合は $1 /$ X倍した値を定量下限值とした。 なお，定量下限值の判定は，月および年平均濃度に対 して行い, 定量下限值未満の場合は解析対象から除外し た。

\subsection{3 非海塩成分の算出}

$\mathrm{SO}_{4}{ }^{2-}(\mathrm{p})$ およびCa ${ }^{2+}(\mathrm{p})$ については, 試料中の $\mathrm{Na}^{+}(\mathrm{p})$ 濃度 と海水中でのモル濃度比とを用いて, 以下の式により非 海塩 (nss: non sea salt) 由来成分濃度を算出した。

$$
\begin{aligned}
& \mathrm{nss}^{-} \mathrm{SO}_{4}{ }^{2-}(\mathrm{p})=\mathrm{SO}_{4}{ }^{2-}(\mathrm{p})-0.0607 \times \mathrm{Na}^{+}(\mathrm{p}) \\
& \mathrm{nss}^{-} \mathrm{Ca}^{2+}(\mathrm{p})=\mathrm{Ca}^{2+}(\mathrm{p})-0.0224 \times \mathrm{Na}^{+}(\mathrm{p})
\end{aligned}
$$

\subsection{4 ガス・粒子間反応の測定結果への影響}

サンプリング期間中，大気中と同様に，フィルター上 ではガスと粒子の間で様々な可逆あるいは不可逆反応が 生じていると考えられるが，フィルターに捕集された後 に生じるこれらの反応によるアーティファクトを分別し て評価することは困難である。そこで, 前年度 ${ }^{4)}$ までと同 様に，平衡関係にあると考えられるガスと粒子について は, 全硝酸 $\left(\mathrm{HNO}_{3}(\mathrm{~g})+\mathrm{NO}_{3}^{-}(\mathrm{p})\right)$, 全アンモニア $\left(\mathrm{NH}_{3}(\mathrm{~g})+\mathrm{NH}_{4}{ }^{+}\right.$ $(\mathrm{p}))$, 全塩化物 $\left(\mathrm{HCl}(\mathrm{g})+\mathrm{Cl}^{-}(\mathrm{p})\right)$ のようにガスと粒子の総 計でも評価した。

\section{2 大気中のガス状および粒子状成分濃度}

\section{2 .1 年平均濃度の地域特性}

ガス状成分について, 地点別年平均濃度を表 5.2 .1 に, 地域区分別の年平均濃度の箱ひげ図を図 5.2.1 に示す。 粒子状成分について, 地点別年平均濃度を表 5.2.2 に, 地域区分別の年平均濃度の箱ひげ図を図 5.2.2 に示す。 ガス状および粒子状成分の総計について, 地点別年平均 濃度を表 5.2.3 に, 地域区分別の年平均濃度の箱ひげ図

\begin{tabular}{|c|c|c|c|c|c|c|}
\hline \multirow[t]{2}{*}{ No. } & \multirow[t]{2}{*}{ 都道府県市 } & \multirow[t]{2}{*}{ 地点名 } & $\mathrm{SO}_{2}(\mathrm{~g})$ & $\mathrm{HNO}_{3}(\mathrm{~g})$ & $\mathrm{HCl}(\mathrm{g})$ & $\mathrm{NH}_{3}(\mathrm{~g})$ \\
\hline & & & \multicolumn{4}{|c|}{$\left(\mathrm{nmol} \mathrm{m}^{-3}\right)$} \\
\hline 1 & 北海道 & 利尻 & 7.1 & 1.8 & 16.2 & 17.8 \\
\hline 2 & 北海道 & 札幌北 & 44.4 & 7.1 & 15.8 & 67.4 \\
\hline 3 & 新潟県 & 新潟曽和 & 13.2 & 13.9 & 23.9 & 69.2 \\
\hline 4 & 新潟県 & 長岡 & 15.1 & 15.7 & 16.9 & 88.4 \\
\hline 5 & 新潟市 & 新潟小新 & 17.5 & 14.2 & 29.8 & 77.0 \\
\hline 6 & 群馬県 & 前橋 & 22.7 & 18.6 & 15.4 & 447.7 \\
\hline 7 & 埼玉県 & 加須 & 23.4 & 32.7 & 33.4 & 204.1 \\
\hline 8 & 千葉県 & 旭 & 14.3 & 4.1 & 14.9 & 3545.2 \\
\hline 9 & 千葉県 & 勝浦 & 19.6 & 5.9 & 27.0 & 67.6 \\
\hline 10 & 千葉県 & 清澄 & 25.7 & 7.7 & 26.8 & 56.6 \\
\hline 11 & 千葉県 & 市原 & 93.2 & 8.7 & 24.1 & 131.1 \\
\hline 12 & 千葉県 & 佐倉 & 34.4 & 16.4 & 34.6 & 123.9 \\
\hline 13 & 長野県 & 長野 & 18.6 & 19.4 & 23.4 & 106.8 \\
\hline 14 & 静岡県 & 静岡北安東 & 30.3 & 24.7 & 24.3 & 74.6 \\
\hline 15 & 富山県 & 射水 & 24.6 & 11.4 & 17.5 & 81.8 \\
\hline 16 & 石川県 & 金沢 & 16.8 & 10.0 & 15.4 & 38.7 \\
\hline 17 & 福井県 & 福井 & 38.7 & 20.0 & 32.5 & 81.4 \\
\hline 18 & 岐阜県 & 伊自良湖 & 13.4 & 9.3 & 7.7 & 36.8 \\
\hline 19 & 愛知県 & 豊橋 & 32.3 & 19.1 & 23.7 & 159.6 \\
\hline 20 & 名古屋市 & 名古屋南 & 47.4 & 26.0 & 31.3 & 130.2 \\
\hline 21 & 和歌山県 & 海南 & 41.9 & 23.8 & 26.5 & 89.1 \\
\hline 22 & 兵庫県 & 神戸須磨 & 70.3 & 29.6 & 30.8 & 80.8 \\
\hline 23 & 鳥取県 & 湯梨浜 & 24.2 & 4.5 & 16.7 & 63.4 \\
\hline 24 & 高知県 & 香北 & 11.3 & 10.4 & 10.0 & 17.1 \\
\hline 25 & 福岡県 & 太宰府 & 45.1 & 24.9 & 23.0 & 126.0 \\
\hline 26 & 大分県 & 大分久住 & 80.1 & 13.1 & 12.0 & 60.7 \\
\hline 27 & 大分県 & 大分 & $(79.6)$ & (19.6) & (16.0) & (61.4) \\
\hline 28 & 宮崎県 & 宮崎 & 50.9 & 11.7 & 30.7 & 128.0 \\
\hline 29 & 鹿児島県 & 鹿児島 & 78.3 & 12.4 & 34.0 & 107.8 \\
\hline 30 & 沖縄県 & 大里 & 15.8 & 4.0 & 28.9 & 317.4 \\
\hline 31 & 沖縄県 & 辺戸岬 & 9.7 & 3.9 & 41.3 & 43.0 \\
\hline & & 全国最低値 & 7.1 & 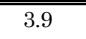 & 7.7 & 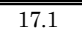 \\
\hline & & 全国最高値 & 93.2 & 32.7 & 41.3 & 3545.2 \\
\hline & & 全国中央值 & 24.4 & 13.9 & 24.0 & 81.6 \\
\hline & & 全国平均值 & 32.7 & 15.4 & 23.6 & 221.3 \\
\hline
\end{tabular}

表5.2.1 ガス状成分の年平均濃度（地点別） 
表5.2.2 粒子状成分の年平均濃度の分布（地域区分別）

\begin{tabular}{|c|c|c|c|c|c|c|c|c|c|c|c|c|}
\hline \multirow[t]{2}{*}{ No. } & \multirow[t]{2}{*}{ 都道府県市 } & \multirow[t]{2}{*}{ 地点名 } & $\mathrm{SO}_{4}{ }^{2}(\mathrm{p})$ & $\mathrm{nss}^{-} \mathrm{SO}_{4}{ }^{2}(\mathrm{p})$ & $\mathrm{NO}_{3}(\mathrm{p})$ & $\mathrm{Cl}(\mathrm{p})$ & $\mathrm{Na}^{+}(\mathrm{p})$ & $\mathrm{K}^{+}(\mathrm{p})$ & $\mathrm{Ca}^{2+}(\mathrm{p})$ & $\mathrm{nss}^{-} \mathrm{Ca}^{2+}(\mathrm{p})$ & $\mathrm{Mg}^{2+}(\mathrm{p})$ & $\mathrm{NH}_{4}{ }^{+}(\mathrm{p})$ \\
\hline & & & \multicolumn{10}{|c|}{$\left(\mathrm{nmol} \mathrm{m}^{-3}\right)$} \\
\hline 1 & 北海道 & 利尻 & 25.0 & 18.9 & 11.7 & 94.3 & 100.3 & 4.0 & 4.2 & 2.0 & 11.3 & 24.2 \\
\hline 2 & 北海道 & 札幌北 & 27.4 & 25.1 & 19.7 & 29.2 & 36.8 & 3.4 & 7.6 & 6.8 & 4.3 & 42.7 \\
\hline 3 & 新潟県 & 新潟曾和 & 36.9 & 33.8 & 18.8 & 35.3 & 51.4 & 3.9 & 5.3 & 4.2 & 6.4 & 50.4 \\
\hline 4 & 新潟県 & 長岡 & 35.7 & 33.9 & 19.8 & 17.6 & 30.7 & 3.5 & 5.3 & 4.6 & 3.9 & 57.7 \\
\hline 5 & 新潟市 & 新潟小新 & 41.6 & 35.9 & 29.3 & 78.3 & 93.7 & 5.0 & 8.3 & 6.2 & 11.1 & 50.3 \\
\hline 6 & 群馬県 & 前橋 & 27.8 & 26.8 & 41.5 & 10.4 & 17.0 & 3.5 & 12.4 & 12.0 & 3.5 & 66.3 \\
\hline 7 & 埼玉県 & 加須 & 33.2 & 31.8 & 41.1 & 12.5 & 23.4 & 3.5 & 8.2 & 7.6 & 3.4 & 73.2 \\
\hline 8 & 千葉県 & 旭 & 36.9 & 31.6 & 43.2 & 87.4 & 86.5 & 1.5 & 7.0 & 5.0 & 9.5 & 81.3 \\
\hline 9 & 千葉県 & 勝浦 & 37.7 & 32.6 & 25.5 & 61.4 & 82.7 & 1.4 & 6.7 & 4.9 & 9.1 & 41.7 \\
\hline 10 & 千葉県 & 清澄 & 36.4 & 32.8 & 24.9 & 33.2 & 60.0 & 1.0 & 4.5 & 3.1 & 6.3 & 41.1 \\
\hline 11 & 千葉県 & 市原 & 47.5 & 42.4 & 56.2 & 79.1 & 83.4 & 3.6 & 48.3 & 46.4 & 12.1 & 48.5 \\
\hline 12 & 千葉県 & 佐倉 & 36.8 & 34.6 & 30.6 & 12.8 & 36.7 & 1.2 & 5.5 & 4.7 & 4.3 & 50.6 \\
\hline 13 & 長野県 & 長野 & 36.9 & 36.1 & 14.7 & 3.2 & 12.7 & 2.8 & 3.9 & 3.6 & 1.5 & 63.9 \\
\hline 14 & 静岡県 & 静岡北安東 & 36.3 & 34.7 & 26.9 & 11.3 & 25.2 & 3.7 & 5.0 & 4.5 & 3.4 & 55.1 \\
\hline 15 & 富山県 & 射水 & 34.4 & 32.8 & 16.7 & 12.9 & 27.4 & 2.9 & 4.1 & 3.5 & 3.5 & 58.5 \\
\hline 16 & 石川県 & 金沢 & 34.7 & 33.0 & 13.6 & 12.3 & 28.3 & 3.5 & 5.2 & 4.6 & 4.1 & 48.4 \\
\hline 17 & 福井県 & 福井 & 51.8 & 48.4 & 25.1 & 38.4 & 54.7 & 5.6 & 9.2 & 8.0 & 9.1 & 80.8 \\
\hline 18 & 岐阜県 & 伊自良湖 & 32.5 & 31.8 & 7.1 & 1.4 & 10.7 & 2.3 & 0.9 & 0.7 & 4.6 & 47.8 \\
\hline 19 & 愛知県 & 豊橋 & 41.3 & 38.8 & 46.2 & 20.9 & 40.8 & 3.9 & 11.7 & 10.8 & 5.1 & 74.7 \\
\hline 20 & 名古屋市 & 名古屋南 & 40.0 & 38.2 & 42.4 & 17.6 & 30.3 & 3.3 & 12.7 & 12.0 & 4.5 & 66.2 \\
\hline 21 & 和歌山県 & 海南 & 43.0 & 40.9 & 25.2 & 14.6 & 35.6 & 3.9 & 10.5 & 9.7 & 4.3 & 62.2 \\
\hline 22 & 兵庫県 & 神戸須磨 & 48.3 & 44.8 & 45.6 & 33.5 & 57.0 & 5.8 & 12.3 & 11.0 & 6.2 & 84.4 \\
\hline 23 & 鳥取県 & 湯梨浜 & 39.8 & 36.9 & 20.1 & 31.8 & 47.8 & 5.4 & 5.4 & 4.3 & 6.8 & 64.8 \\
\hline 24 & 高知県 & 香北 & 40.2 & 39.4 & 6.3 & 1.5 & 13.2 & 2.3 & 5.8 & 5.5 & 1.8 & 55.1 \\
\hline 25 & 福岡県 & 太宰府 & 55.7 & 53.1 & 50.0 & 26.0 & 42.7 & 6.1 & 13.2 & 12.3 & 6.4 & 102.1 \\
\hline 26 & 大分県 & 大分久住 & 39.4 & 38.7 & 18.9 & 3.3 & 12.5 & 2.5 & 4.9 & 4.6 & 2.5 & 69.4 \\
\hline 27 & 大分県 & 大分 & (51.3) & (50.1) & (21.3) & (3.6) & (18.6) & (3.7) & (5.6) & (5.1) & $(3.2)$ & (83.9) \\
\hline 28 & 宮崎県 & 宮崎 & 59.5 & 55.5 & 36.5 & 47.0 & 66.8 & 4.3 & 6.1 & 4.6 & 6.7 & 114.2 \\
\hline 29 & 鹿児島県 & 鹿児島 & 48.5 & 44.8 & 33.9 & 43.7 & 60.3 & 4.2 & 8.0 & 6.7 & 7.2 & 86.9 \\
\hline 30 & 沖縄県 & 大里 & 41.9 & 34.8 & 24.8 & 96.2 & 116.2 & 4.5 & 9.8 & 7.2 & 14.0 & 39.6 \\
\hline 31 & 沖縄県 & 辺戸岬 & 49.6 & 36.2 & 26.6 & 202.4 & 219.9 & 6.4 & 9.2 & 4.3 & 25.4 & 30.8 \\
\hline & & 全国最低值 & 25.0 & 18.9 & 6.3 & 1.4 & 10.7 & 1.0 & 0.9 & 0.7 & 1.5 & 24.2 \\
\hline & & 全国最高值 & 59.5 & 55.5 & 56.2 & 202.4 & 219.9 & 6.4 & 48.3 & 46.4 & 25.4 & 114.2 \\
\hline & & 全国中央値 & 38.5 & 35.4 & 25.4 & 27.6 & 41.8 & 3.6 & 6.8 & 4.9 & 5.6 & 58.1 \\
\hline & & 全国平均値 & 39.9 & 36.6 & 28.1 & 39.0 & 53.5 & 3.6 & 8.7 & 7.5 & 6.7 & 61.1 \\
\hline
\end{tabular}

注) 全国最低值は網掛け, 全国最高值は白抜き, 参考值は（）で示した。

注) 参考值は最低值, 最高值, 中央値, 平均值から除外した。
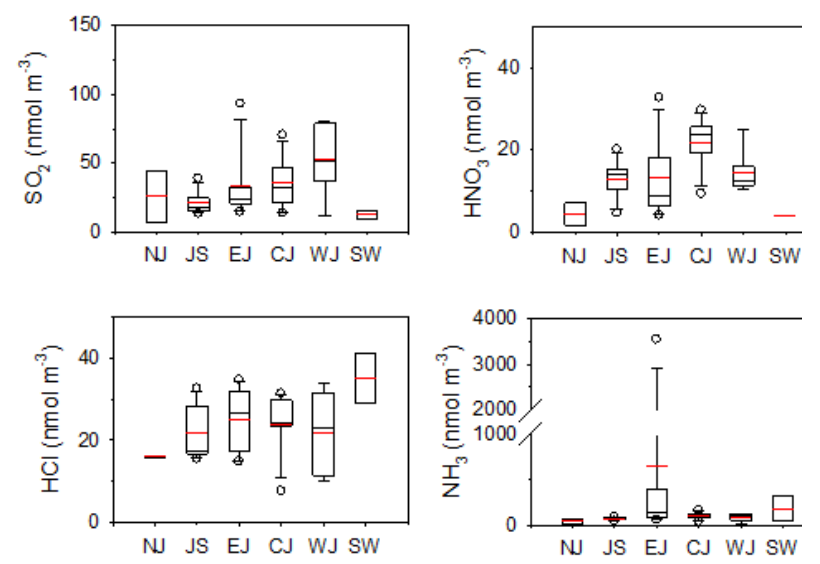

図5.2.1 ガス状成分の年平均濃度の分布
(地域区分別)
を図 5.2.3 に示す。箱ひげ図は, 各地域区分の地点別年 平均濃度の $25 \%$ 点と $75 \%$ 点がボックスの両端で表され, そのボックス内の黒線は中央值を, 赤線は平均值を表す。 エラーバーは 10\%点と $90 \%$ 点を表し, 10～90\%点から外れ る值は○で示されている。

\subsubsection{1 ガス状成分}

$\mathrm{SO}_{2}(\mathrm{~g})$ の年平均濃度の範囲は7.1 93.2 $\mathrm{nmol} \mathrm{m}^{-3}$ (平均 值32. $7 \mathrm{nmol} \mathrm{m}^{-3}$ )であり, 最高值は市原, 次いで大分久住, 最低值は利尻であった。市原は重油ボイラーが多く存在 する工業地帯の影響で $\mathrm{SO}_{2}(\mathrm{~g})$ 濃度が高いと考えられる。 $\mathrm{SO}_{2}(\mathrm{~g})$ はWJで高く, NJ, JSおよびSWで低い傾向がみられ た。

$\mathrm{HNO}_{3}(\mathrm{~g})$ の年平均濃度の範囲は3.9 32.7 nmol m${ }^{-3}$ (平均 值15. $4 \mathrm{nmol} \mathrm{m}^{-3}$ )であり, 最高值は加須, 次いで神戸須磨, 最低值は辺戸岬であった。 $\mathrm{HNO}_{3}(\mathrm{~g})$ はCJで高く, NJおよび SWで低い傾向がみられた。

$\mathrm{HCl}(\mathrm{g})$ の年平均濃度の範囲は7.7 41.3 $\mathrm{nmol} \mathrm{m}^{-3}$ (平均 值23. $6 \mathrm{nmol} \mathrm{m}^{-3}$ )であり, 最高值は辺戸岬, 次いで佐倉, 最低值は伊自良湖であった。 HCl $(\mathrm{g})$ はSWで高く, NJで低 

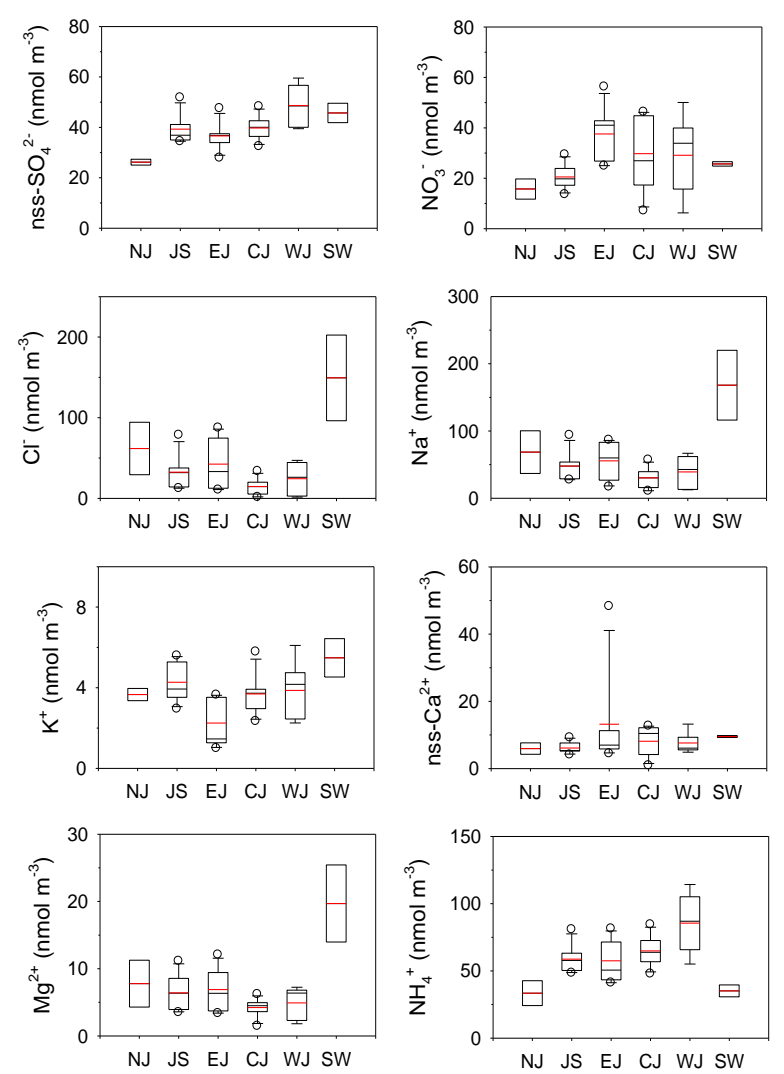

図5.2.2 粒子状成分の年平均濃度の分布 （地域区分別）

い傾向がみられた。

$\mathrm{NH}_{3}(\mathrm{~g})$ の年平均濃度の範囲は17. 1〜3545. $2 \mathrm{nmol} \mathrm{m}^{-3}$ (平均值221. $3 \mathrm{nmol} \mathrm{m}^{-3}$ ) であり, 最高值は旭, 次いで前橋, 最低值は香北であった。 $\mathrm{NH}_{3}(\mathrm{~g})$ 濃度はEJの旭や前橋, SW の大里のように畜産業の影響を受けていると考えられる 地点や都市部で高い傾向がみられた。

\subsubsection{2 粒子状成分}

$\mathrm{SO}_{4}^{2-}$ (p)の年平均濃度の範囲は25.0 $59.5 \mathrm{nmol} \mathrm{m}{ }^{-3}$ (平 均值 $39.9 \mathrm{nmol} \mathrm{m}^{-3}$ ), $\mathrm{nss}^{-} \mathrm{SO}_{4}{ }^{2-}$ (p) は18.9〜 $55.5 \mathrm{nmol} \mathrm{m}^{-3}$ (平 均值 $36.6 \mathrm{nmol} \mathrm{m}^{-3}$ ) であり, いずれも最高值は宮崎, 次い で太宰府, 最低值は利尻であった。 $\mathrm{nss}^{-} \mathrm{SO}_{4}{ }^{2-}(\mathrm{p})$ 濃度はWJ およびSWで高く, NJで低くなり, 西高東低の傾向がみら れた。このような $\mathrm{ns}^{-} \mathrm{SO}_{4}{ }^{2-}(\mathrm{p})$ 濃度の分布は, Aikawa et al. $(2008)^{5)}$ が指摘しているように, アジア大陸の污染大気 の移流の影響を反映していると考えられる。

$\mathrm{NO}_{3}^{-}$(p)の年平均濃度の範囲は6.3〜 $56.2 \mathrm{nmol} \mathrm{m}^{-3}$ (平均 值28. $1 \mathrm{nmol} \mathrm{m}^{-3}$ )であり, 最高值は市原, 次いで太宰府, 最低值は香北であった。 $\mathrm{NO}_{3}{ }^{-}(\mathrm{p})$ 濃度はEJで高く, NJで低 い傾向がみられた。

$\mathrm{Cl}^{-}$(p)の年平均濃度の範囲は1.4〜202.4 $\mathrm{nmol} \mathrm{m}^{-3}$ (平均 值39. $0 \mathrm{nmol} \mathrm{m}^{-3}$ )であり, 最高值は辺戸岬, 次いで大里, 最低值は伊自良湖であった。 $\mathrm{Cl}^{-}(\mathrm{p})$ 濃度はSWで高い傾向 がみられた。
表5.2.3 ガス状および粒子状成分の総計の 年平均濃度 (地点別)

\begin{tabular}{|c|c|c|c|c|c|c|}
\hline \multirow[t]{2}{*}{ No. } & \multirow[t]{2}{*}{ 都道府県市 } & \multirow[t]{2}{*}{ 地点名 } & $\begin{array}{c}\text { 全硫黄 } \\
\mathrm{SO}_{2}(\mathrm{~g}) \mathrm{ns8}-\mathrm{SO}^{2}(\mathrm{p})\end{array}$ & $\begin{array}{c}\text { 全硝酸 } \\
\mathrm{HNO}_{2}(\mathrm{~g})+\mathrm{NO}_{3}(\mathrm{p})\end{array}$ & $\begin{array}{l}\text { 全垛化物 } \\
\mathrm{HCI(g)+CI(p)}\end{array}$ & $\begin{array}{l}\text { 全アンモニア } \\
\mathrm{NH}^{\prime}(\mathrm{g})+\mathrm{NH}_{\mathrm{f}}^{+}(\mathrm{p})\end{array}$ \\
\hline & & & \multicolumn{4}{|c|}{$\left(\mathrm{nmol} \mathrm{m}^{3}\right)$} \\
\hline \multirow{2}{*}{\begin{tabular}{l|}
1 \\
2
\end{tabular}} & \multirow{3}{*}{$\begin{array}{l}\text { 北海道 } \\
\text { 北海道 } \\
\text { 新潟県 }\end{array}$} & 利尻 & 26.0 & 10.0 & 110.5 & 42.0 \\
\hline & & \multirow{2}{*}{$\begin{array}{l}\text { 札幌北 } \\
\text { 新潟曾和 }\end{array}$} & 69.5 & 26.8 & 45.0 & 110.0 \\
\hline 3 & & & 46.9 & 32.7 & 59.2 & 119.7 \\
\hline 4 & 新潟県 & 長岡 & 48.9 & 35.5 & 34.5 & 146.2 \\
\hline 5 & 新潟市 & \multirow{2}{*}{$\begin{array}{l}\text { 新潟小新 } \\
\text { 前橋 }\end{array}$} & 53.4 & 43.6 & 108.2 & 127.3 \\
\hline 6 & 群馬県 & & 49.5 & 60.1 & 25.8 & 514.1 \\
\hline 7 & 埼玉県 & 加須 & 55.1 & 73.8 & 45.9 & 277.4 \\
\hline 8 & 千葉県 & 旭 & 46.0 & 39.1 & 102.2 & 3626.6 \\
\hline 9 & 千葉県 & \multirow{2}{*}{$\begin{array}{l}\text { 勝浦 } \\
\text { 清澄 }\end{array}$} & 52.2 & 31.4 & 88.4 & 109.3 \\
\hline 10 & 千葉県 & & 58.5 & 32.6 & 59.9 & 97.7 \\
\hline 11 & 千葉県 & 市原 & 135.6 & 64.9 & 103.2 & 179.7 \\
\hline 12 & 千葉県 & 佐倉 & 69.0 & 47.0 & 47.4 & 174.5 \\
\hline 13 & 長野県 & \multirow{2}{*}{$\begin{array}{c}\text { 長野 } \\
\text { 静岡北安東 }\end{array}$} & 54.7 & 34.1 & 26.6 & 170.6 \\
\hline 14 & 静岡県 & & 65.1 & 51.6 & 35.5 & 129.7 \\
\hline 15 & 富山県 & $\begin{array}{c}\text { 静岡北安東 } \\
\text { 射水 }\end{array}$ & 57.3 & 28.1 & 30.4 & 140.3 \\
\hline 16 & 石川県 & 金沢 & 49.9 & 23.6 & 27.7 & 87.1 \\
\hline 17 & 福井県 & 福井 & 87.2 & 45.1 & 70.9 & 162.2 \\
\hline 18 & 岐阜県 & 伊自良湖 & 45.2 & 16.4 & 9.1 & 84.6 \\
\hline 19 & 愛知県 & 豊橋 & 71.0 & 65.3 & 44.6 & 234.4 \\
\hline 20 & 名古屋市 & \multirow{2}{*}{$\begin{array}{l}\text { 名古屋南 } \\
\text { 海南 }\end{array}$} & 85.6 & 68.4 & 48.9 & 196.5 \\
\hline 21 & 和歌山県 & & 82.8 & 49.0 & 41.1 & 151.3 \\
\hline 22 & 兵庫県 & 神戸須磨 & 115.1 & 75.2 & 64.3 & 165.2 \\
\hline 23 & 鳥取県 & \multirow{2}{*}{$\begin{array}{l}\text { 湯梨浜 } \\
\text { 香北 }\end{array}$} & 61.1 & 15.6 & 48.5 & 128.1 \\
\hline 24 & 高知県 & & 50.7 & 16.6 & 11.5 & 72.1 \\
\hline 25 & 福岡県 & 太宰府 & 98.2 & 74.9 & 49.1 & 228.0 \\
\hline 26 & 大分県 & 大分久住 & 118.8 & 32.0 & 15.3 & 130.1 \\
\hline 27 & 大分県 & \multirow{2}{*}{$\begin{array}{l}\text { 大分 } \\
\text { 宮崎 }\end{array}$} & (129.7) & (40.8) & (19.6) & (145.3) \\
\hline 28 & 宮崎県 & & 106.4 & 48.2 & 77.7 & 242.2 \\
\hline 29 & 鹿児島県 & 鹿児島 & 123.2 & 46.3 & 77.6 & 194.7 \\
\hline 30 & 沖縄県 & 大里 & 50.6 & 28.7 & 125.1 & 357.0 \\
\hline 31 & 沖縄県 & 辺戸岬 & 45.9 & 30.5 & 243.7 & 73.8 \\
\hline & & 全国最低值 & 26.0 & 10.0 & 9.1 & 42.0 \\
\hline & & 全国最高值 & 135.6 & 75.2 & 243.7 & 3626.6 \\
\hline & & 全国中央值 & 57.9 & 37.3 & 48.7 & 148.7 \\
\hline & & 全国平均值 & 69.3 & 41.6 & 62.6 & 282.4 \\
\hline
\end{tabular}
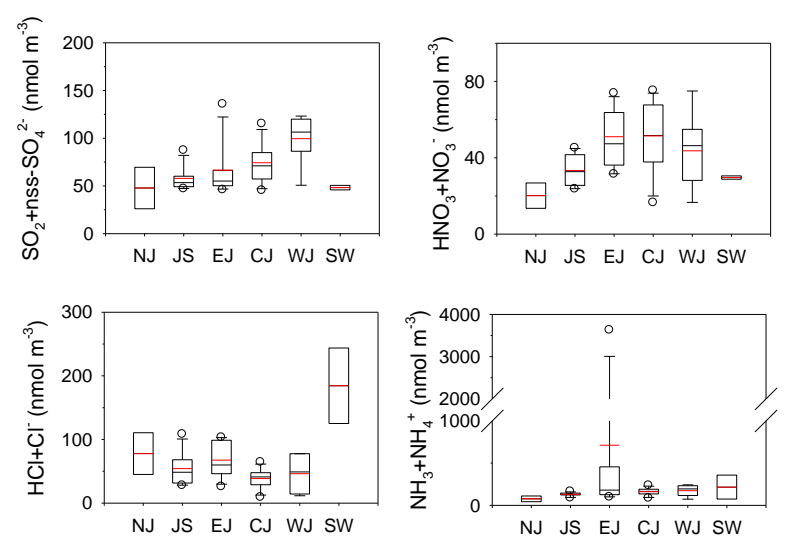

図5.2.3 ガス状および粒子状成分の 年平均濃度の分布（地域区分別）

$\mathrm{Na}^{+}(\mathrm{p})$ の年平均濃度の範囲は10.7 219.9 $\mathrm{nmol} \mathrm{m}$ (平 均值 $53.5 \mathrm{nmol} \mathrm{m}^{-3}$ ) であり, 最高值は辺戸岬, 次いで大里, 最低值は伊自良湖であった。 $\mathrm{Na}^{+}(\mathrm{p})$ 濃度はSWで高い傾向 がみられた。

$\mathrm{K}^{+}(\mathrm{p})$ の年平均濃度の範囲は1. 0 6.4 $\mathrm{nmol} \mathrm{m}^{-3}$ (平均值 $3.6 \mathrm{nmol} \mathrm{m}^{-3}$ )であり, 最高值は辺戸岬，次いで太宰府， 最低值は清澄であった。 $K^{+}(p)$ 濃度はSWで高い傾向がみら れた。

$\mathrm{Ca}^{2+}(\mathrm{p})$ の年平均濃度の範囲は0.9〜 $48.3 \mathrm{nmol} \mathrm{m}^{-3}$ (平均 值8. $7 \mathrm{nmol} \mathrm{m}^{-3}$ ), $\mathrm{nss}^{-} \mathrm{Ca}^{2+}(\mathrm{p})$ は0.7〜 46.4 $\mathrm{nmol} \mathrm{m}^{-3}$ (平均 值7. $5 \mathrm{nmol} \mathrm{m}^{-3}$ ) であり, いずれも最高值は市原, 次いで 
太宰府，最低值は伊自良湖であった。 $\mathrm{nss}^{-} \mathrm{Ca}^{2+}(\mathrm{p})$ 濃度は EJで高い傾向がみられた。

$\mathrm{Mg}^{2+}(\mathrm{p})$ の年平均濃度の範囲は1.5〜25. $4 \mathrm{nmol} \mathrm{m}$ (平均 值6. $7 \mathrm{nmol} \mathrm{m} \mathrm{m}^{-3}$ )であり, 最高值は辺戸岬, 次いで大里, 最低值は長野であった。 $\mathrm{Mg}^{2+}(\mathrm{p})$ 濃度はSWで高い傾向がみ られた。

$\mathrm{NH}_{4}^{+}(\mathrm{p})$ の年平均濃度の範囲は24.2 114.2 nmol m (平 $^{-3}$ 均值 $\left.61.1 \mathrm{nmol} \mathrm{m}^{-3}\right)$ であり, 最高值は宮崎, 次いで太宰府, 最低值は利尻であった。 $\mathrm{NH}_{4}^{+}(\mathrm{p})$ 濃度はWJで高く, NJおよ びSWで低い傾向がみられた。

\section{2.1.3 ガス状および粒子状成分濃度の総計}

非海塩由来の全硫黄 $\left(\mathrm{SO}_{2}(\mathrm{~g})+\mathrm{nss}^{-} \mathrm{SO}_{4}{ }^{2-}(\mathrm{p})\right)$ の年平均濃 度の範囲は26.0 135.6 $\mathrm{nmol} \mathrm{m}^{-3}$ (平均值69.3 $\mathrm{nmol} \mathrm{m}^{-3}$ ) であり, 最高值は市原, 次いで鹿児島, 最低值は利尻で あった。全硫黄濃度はWJで高く, NJで低い傾向がみられ た。

全硝酸 $\left(\mathrm{HNO}_{3}(\mathrm{~g})+\mathrm{NO}_{3}^{-}(\mathrm{p})\right)$ の年平均濃度の範囲は10.0〜 $75.2 \mathrm{nmol} \mathrm{m}^{-3}$ (平均值 $41.6 \mathrm{nmol} \mathrm{m}^{-3}$ ) であり, 最高值は神 戸須磨, 次いで太宰府, 最低值は利尻であった。全硝酸 濃度はEJおよびCJで高く，NJで低い傾向がみられた。

全塩化物 $\left(\mathrm{HCl}(\mathrm{g})+\mathrm{Cl}^{-}(\mathrm{p})\right)$ の年平均濃度の範囲は9.1〜 $243.7 \mathrm{nmol} \mathrm{m}^{-3}$ (平均值62.6 $\mathrm{nmol} \mathrm{m}^{-3}$ ) であり, 最高值は 辺戸岬, 次いで大里, 最低值は伊自良湖であった。全塩
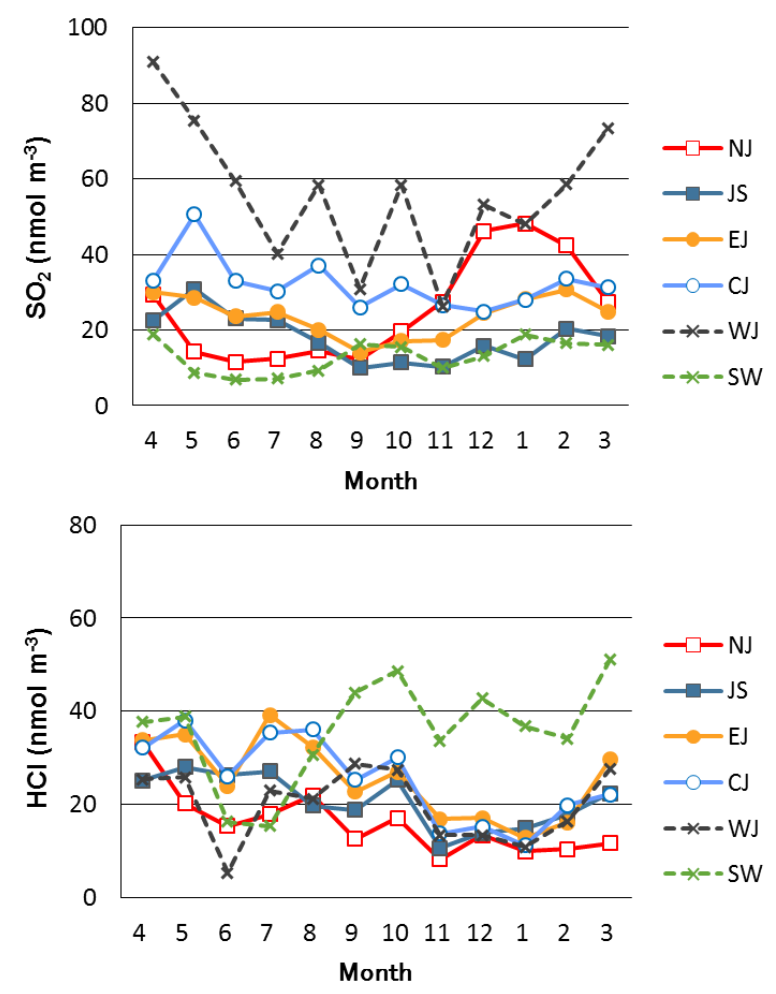

化物濃度はSWで高い傾向がみられた。

全アンモニア $\left(\mathrm{NH}_{3}(\mathrm{~g})+\mathrm{NH}_{4}^{+}(\mathrm{p})\right)$ の年平均濃度の範囲は 42. 0 〜626. $6 \mathrm{nmol} \mathrm{m}^{-3}$ (平均值282. $4 \mathrm{nmol} \mathrm{m}^{-3}$ ) であり,

最高值は旭, 次いで前橋, 最低值は利尻であった。全 アンモニア濃度はEJとSWのように周辺の畜産業の影響を 受けている地点や都市部で高い傾向が見られた。

\subsection{2 経月変化および地域特性}

地点別月平均濃度を見ると, ほとんどの成分は6つの地 域区分 $(\mathrm{NJ}, \mathrm{JS}, \mathrm{EJ}, \mathrm{CJ}, \mathrm{WJ}, \mathrm{SW})$ ごとに濃度変動パター ンが似ていた。ここでは，外れ值の影響を小さくするた め, 地域区分別の中央值をもとに，月変化や包括的な地 域特性を述べる。なお, 気象庁の予報用語 ${ }^{6}$ に従い, 文中, 春季 (春) は3〜 月, 夏季(夏) は6〜8月, 秋季 (秋)は $9 \sim 11$ 月，冬季(冬)は12〜2月のことをそれぞれ指す。

\subsubsection{1 ガス状成分}

地域区分別のガス状成分濃度の経月変化を図5.2.4に 示す。 $\mathrm{SO}_{2}(\mathrm{~g})$ 濃度は, 冬季から春季に高くなる傾向がみ られた。冬季の $\mathrm{SO}_{2}(\mathrm{~g})$ 濃度の増加はNJで顕著であり, 冬 季の暖房等の使用に伴う地域污染の影響が考えられる。 $\mathrm{SO}_{2}(\mathrm{~g})$ 濃度はWJで最も高く, アジア大陸に近いWJでは, 大陸から排出される $\mathrm{SO}_{2}(\mathrm{~g})$ の影響を強く受けている可能 性がある。また，WJでは2015年5月に爆発的噴火が起こつ た口永良部島や, 活発な噴火活動が継続する桜島や阿蘇
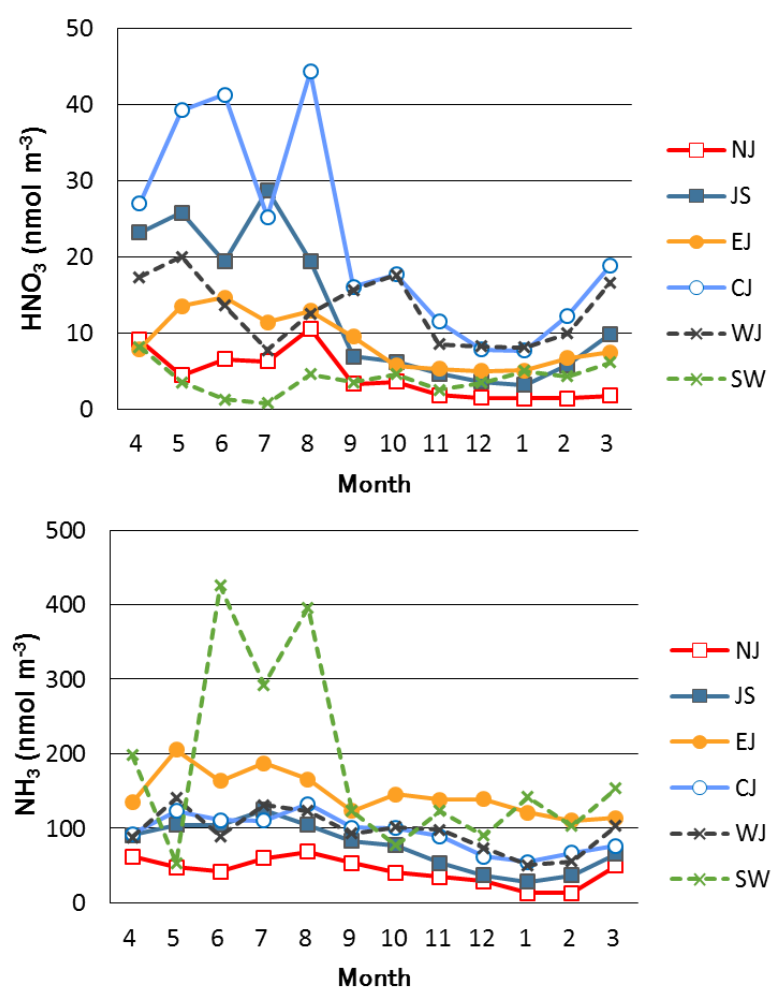

図5.2.4 ガス状成分濃度の経月変化（地域区分別） 
山苂を起源とする火山ガスの影響を受けていることも考 えられる。

$\mathrm{HNO}_{3}(\mathrm{~g})$ 濃度は春季から夏季にかけて高く, 秋季から冬 季にかけて低くなる傾向がみられた。春季から夏季にか けての高濃度はCJおよびJSで特に顕著であった。春季か ら夏季に $\mathrm{HNO}_{3}(\mathrm{~g})$ 濃度が高くなる要因としては, 気温の上 昇によって光化学反応が活発になり窒素酸化物から $\mathrm{HNO}_{3}(\mathrm{~g})$ への酸化が促進されるためや，揮発性粒子である $\mathrm{NH}_{4} \mathrm{NO}_{3}$ などの解離が進むためなどが考えられる。

$\mathrm{HCl}(\mathrm{g})$ 濃度はSWを除いて冬季に低くなる傾向がみられ た。 $\mathrm{HCl}(\mathrm{g})$ の発生源としては, 廃棄物焼却施設, 火山ガ ス，海塩粒子のクロリンロスなどが考えられる。

$\mathrm{NH}_{3}(\mathrm{~g})$ 濃度は，夏季に高く冬季に低くなる傾向がみら れた。 $\mathrm{NH}_{3}(\mathrm{~g})$ 濃度の季節变化は, 気温が上昇すると $\mathrm{NH}_{4} \mathrm{NO}_{3}$ などの揮発性粒子が解離することによりガス化し，逆に 気温が低下すると粒子化することによると考えられる。 $\mathrm{NH}_{3}(\mathrm{~g})$ 濃度の高いSWおよびEJでは地域污染の影響が強い と考えられる。特に, EJの旭では, 周辺に養豚場, 養鵎 場および肥料工場が立地するため，ごく近傍の発生源の 影響を強く受けて一年中 $\mathrm{NH}_{3}(\mathrm{~g})$ 濃度が高い(月平均濃度 : 2910 4510 $\left.\mathrm{nmol} \mathrm{m}^{-3}\right)$ 。SWでは夏季の高濃度が顕著であ るが,これは大里で極めて高い濃度を示したためである。 大里も周辺の畜産業の影響を強く受けていると考えられ る。

\subsubsection{2 粒子状成分}

粒子状成分の地域別年平均当量濃度を図5.2.5に示す。 どの地域でも陰イオンと陽イオンは同量程度であり, 分 析した8成分でイオンバランスはおおむねとれていた。総 当量濃度は, SWで最も高かった。NJおよびSWを除く地域 では, 陰イオンは $\mathrm{SO}_{4}{ }^{2-}$, 陽イオンは $\mathrm{NH}_{4}^{+}$の占める割合が高 かった。NJおびSWでは $\mathrm{Na}^{+} と \mathrm{Cl}^{-}$の占める割合が高く, 海 塩粒子の寄与が大きいと考えられる。EJでは, 他の地域 と比べて $\mathrm{NO}_{3}{ }^{-}$の割合が高かった。

粒子状成分濃度の経月変化を図5.2.6に示す。 $\mathrm{nsS}^{-}$ $\mathrm{SO}_{4}{ }^{2-}(\mathrm{p})$ 濃度は, 春季から夏季にかけて高くなる地域が多 かった。また, 夏季を除いてSWやWJで高く, NJで低い傾 向がみられた。

$\mathrm{NO}_{3}{ }^{-}(\mathrm{p})$ 濃度は全国的に, 夏季に低くなる傾向がみられ た。夏季の低濃度は, $\mathrm{NH}_{4} \mathrm{NO}_{3}$ などの揮発性粒子が解離した 影響が考えられる。

$\mathrm{NH}_{4}^{+}(\mathrm{p})$ 濃度はWJで高い傾向がみられた。 $\mathrm{NH}_{4}^{+}(\mathrm{p})$ 濃度の 変動は, $\mathrm{nss}^{-} \mathrm{SO}_{4}{ }^{2-}(\mathrm{p})$ 濃度とよく似ていた。

$\mathrm{nss}^{-} \mathrm{Ca}^{2+}(\mathrm{p})$ 濃度は春季に高い傾向がみられた。2015年 度は4〜6月に気象庁によって黄砂が観測されており ${ }^{3)}$,

黄砂の飛来の影響を受けて $\mathrm{nss}^{-} \mathrm{Ca}^{2+}(\mathrm{p})$ 濃度は高くなった と考えられる。 $\mathrm{nss}^{-} \mathrm{Ca}^{2+}(\mathrm{p})$ の高濃度は, 黄砂以外に地域 的発生源の影響が大きいと考えられ, 年平均 $\mathrm{Ca}^{2+}(\mathrm{p})$ 濃度

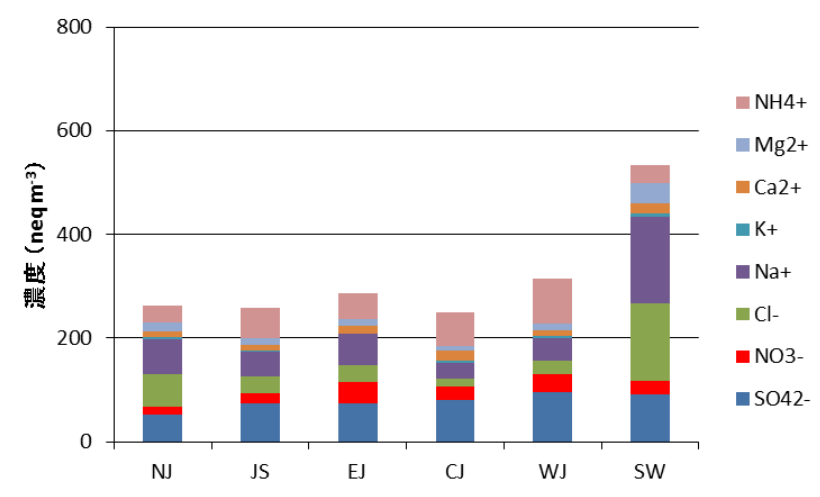

図5.2.5 粒子状成分の年平均当量濃度（地域区分別）

が最も高い市原では，近傍のセメント工場や石灰工場の 影響を受けている可能性が高いと考えられる。

$\mathrm{K}^{+}(\mathrm{p})$ 濃度は, SWにおいてやや高かった。 $\mathrm{K}^{+}(\mathrm{p})$ は, 海塩 粒子やバイオマス燃焼の影響が考えられる。

$\mathrm{Na}^{+}(\mathrm{p}), \mathrm{Cl}^{-}(\mathrm{p})$ および $\mathrm{Mg}^{2+}(\mathrm{p})$ 濃度は, 1 年を通して SWで 高かった。SWの調查地点は海に近いため，海塩粒子の影 響が大きいと考えられる。

\subsubsection{3 ガス状および粒子状成分の総計}

非海塩由来の全硫黄 $\left(\mathrm{SO}_{2}(\mathrm{~g})+\mathrm{nss}^{-} \mathrm{SO}_{4}{ }_{4}^{2-}(\mathrm{p})\right)$, 全硝酸 $\left(\mathrm{HNO}_{3}(\mathrm{~g})+\mathrm{NO}_{3}^{-}(\mathrm{p})\right)$, 全塩化物 $\left(\mathrm{HCl}(\mathrm{g})+\mathrm{Cl}^{-}(\mathrm{p})\right)$, 全アンモ ニア $\left(\mathrm{NH}_{3}(\mathrm{~g})+\mathrm{NH}_{4}{ }^{+}(\mathrm{p})\right)$ 濃度の経月変化を図5.2.7 亿示す。

非海塩由来の全硫黄 $\left(\mathrm{SO}_{2}(\mathrm{~g})+\mathrm{nss}^{-} \mathrm{SO}_{4}{ }^{2-}(\mathrm{p})\right)$ 濃度は全国 的に, 冬季から春季にかけて高い傾向がみられた。地域 分布をみると，越境污染や火山ガスの影響を受けやすい と考えられるWJで高かった。

全硝酸 $\left(\mathrm{HNO}_{3}(\mathrm{~g})+\mathrm{NO}_{3}{ }^{-}(\mathrm{p})\right)$ 濃度は, 春季に高くなる傾向 がみられた。

全塩化物 $\left(\mathrm{HCl}(\mathrm{g})+\mathrm{Cl}^{-}(\mathrm{p})\right)$ 濃度の季節変化は明確でな かった。SWでは1年を通して高濃度であった。

全アンモニア $\left(\mathrm{NH}_{3}(\mathrm{~g})+\mathrm{NH}_{4}{ }^{+}(\mathrm{p})\right)$ 濃度は, 春季から夏季に 高い傾向がみられた。地域分布をみると，周辺の発生源 からのアンモニアの寄与が大きいと考えられるEJやSWで 高く, NJで低かった。

\subsection{3 自動測定機による $\mathrm{SO}_{2}$ 濃度との比較}

$\mathrm{FP}$ 法によって測定した $\mathrm{SO}_{2}(\mathrm{~g})$ 濃度と, 自動測定機によ つて測定した $\mathrm{SO}_{2}(\mathrm{~g})$ 濃度との比較を図5.2.8に示す。図に は, 12 地点(利尻, 札幌北, 長岡, 前橋, 加須, 長野, 射 水, 豊橋, 海南, 太宰府, 鹿児島および辺戸岬) の月平均 值を用いている。図から, 両濃度がほぼ一致する地点と, 自動測定機による $\mathrm{SO}_{2}(\mathrm{~g})$ 濃度の方が高い傾向を示す地点 がみられたが，おおむね $0.5 〜 2$ 倍の範囲内であった。自 動測定機による $\mathrm{SO}_{2}(\mathrm{~g})$ 濃度の方が高くなる要因としては, FP法の捕集不良や分析誤差, 装置設置場所の違い(FP法は 屋上，自動測定機は地上で測定など)に加えて，紫外線 

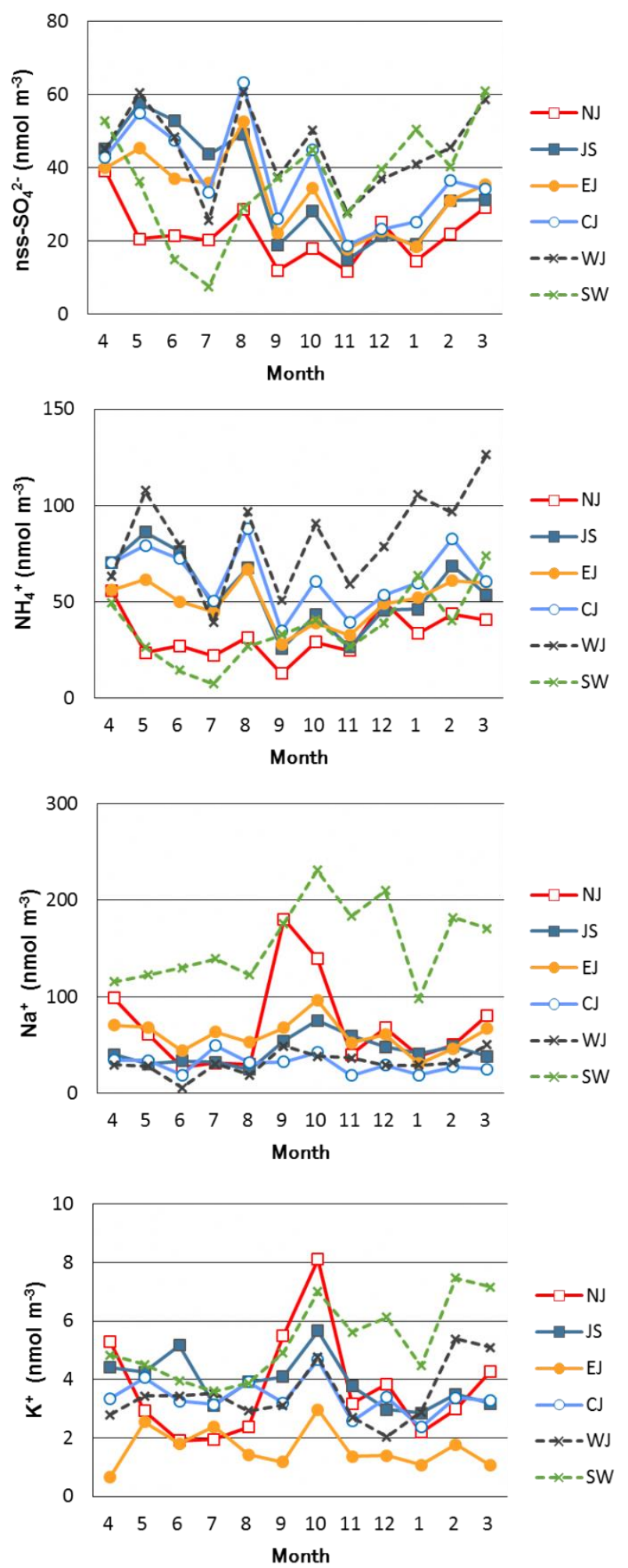
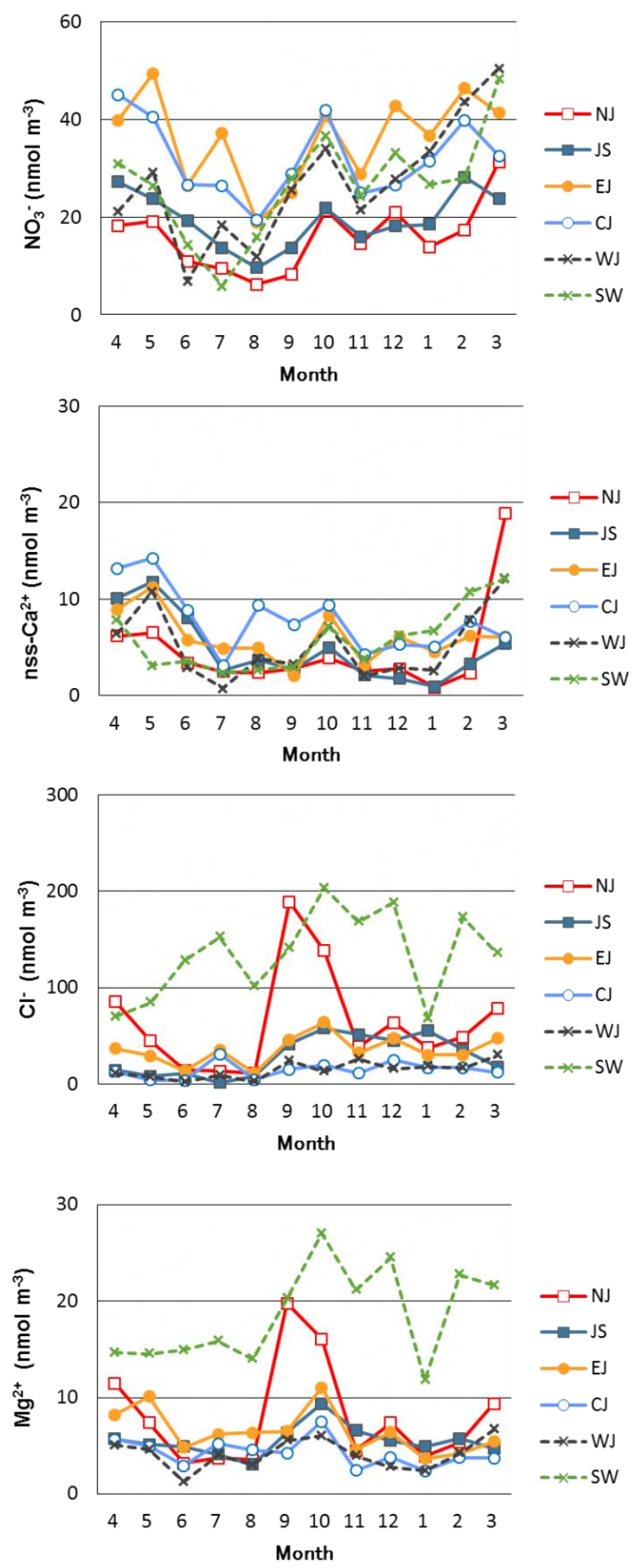

図5.2.6 粒子状成分濃度の経月変化（地域区分別）

蛍光法自動測定機の1時間平均值の測定レンジ $(0 \sim 0.01$ ppmから0〜1.00 ppm) ${ }^{9)}$ が実際の大気濃度と比べて高い ことも考えられる。今回, 濃度差が大きかった地点（図 中に○で示したデータ）では, 自動測定機の不具合を発 見することができたことから，FP法と自動測定機の值を 比較することで, 測定の精度管理につながることが期待
できる。

\subsection{4 ガス状および粒子状成分の経年変化}

アジア地域では，1980年代後半から中国を中心に硫黄 酸化物や窒素酸化物などの大気污染物質の排出量が増大 しており，日本の大気環境に影響を与えていると考えら れる ${ }^{10)}$ 。これまでの本調査からは，1999～2006年度に 

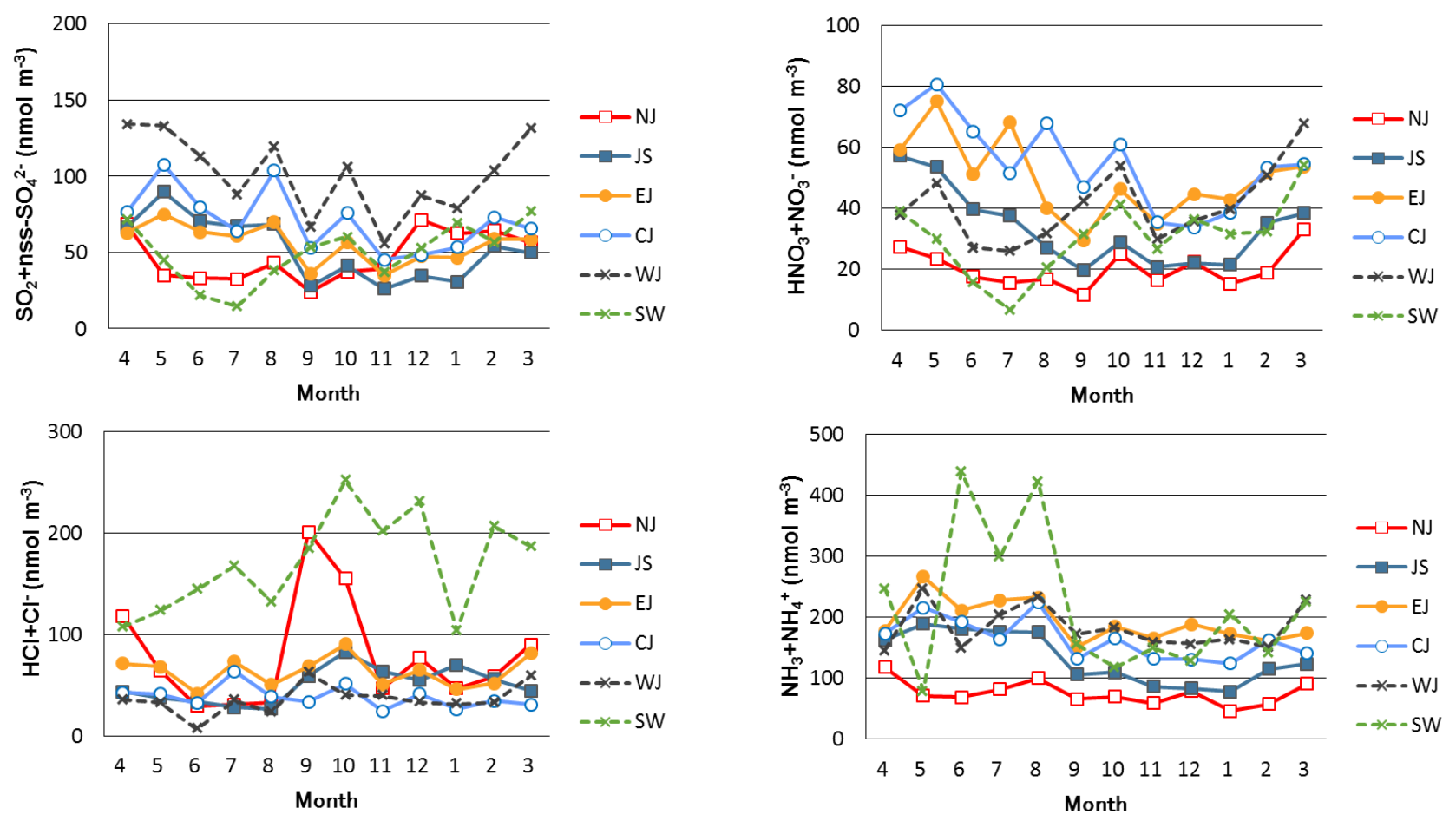

図5.2.7 ガス状および粒子状成分濃度の総計の経月変化（地域区分別）

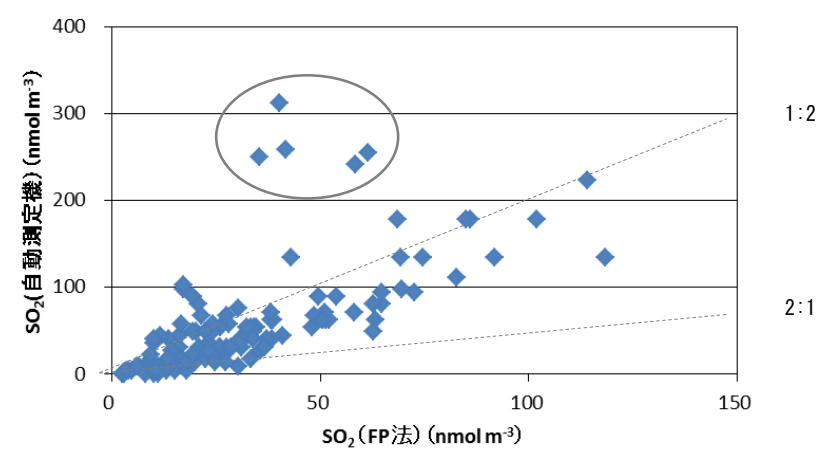

図5.2.8 FP法および自動測定機によるS $\mathrm{S}_{2}$ 濃度

$\mathrm{nsS}^{-} \mathrm{SO}_{4}{ }^{2-}(\mathrm{p})$ 濃度が経年的に増加していたが, 2005〜2007 年度を境に減少傾向に転じている傾向がみられ，特にWJ とJSで越境大気污染の影響を強く受けている可能性が示 唆されている ${ }^{11,12)}$ 。また, 2003〜2012年度の結果からは, $\mathrm{SO}_{2}(\mathrm{~g}), \mathrm{HNO}_{3}(\mathrm{~g}), \mathrm{NH}_{3}(\mathrm{~g}), \mathrm{nss}^{-} \mathrm{SO}_{4}{ }^{2-}(\mathrm{p}), \mathrm{NH}_{4}{ }^{+}(\mathrm{p})$ 濃度は減 少傾向がみられたが，それ以外の成分では目立った変動 はみられなかったことが報告されている ${ }^{13)}$ こここでは, 第4次調查 (2003〜2008年度)および第5次調査 (2009〜 2015年度)の結果をもとに, ガス状および粒子状成分濃度 の経年変化を検討する。

表5.2.4および図5.2.9に示したのはガス状および粒子 状成分濃度の年度別全国中央值である。年によって調査 地点は異なるうえ, 地域污染の影響を強く受ける地点も あるため, 中央值を用いて日本全体の濃度変動を把握し
た。2003年度から 2015 年度にかけて, $\mathrm{SO}_{2}(\mathrm{~g}), \mathrm{HNO}_{3}(\mathrm{~g})$ お よび $\mathrm{NH}_{3}(\mathrm{~g})$ 濃度は減少傾向がみられた。 $\mathrm{SO}_{2}(\mathrm{~g})$ やHNO $_{3}(\mathrm{~g})$ 濃度の減少傾向は, 日本の平均 $\mathrm{SO}_{2}(\mathrm{~g})$ や $\mathrm{NO}_{\mathrm{x}}$ 濃度がゆるや かに減少している状況と一致する ${ }^{14)}$ 。 $\mathrm{HNO}_{3}(\mathrm{~g}) \mathrm{PNH}_{3}(\mathrm{~g})$ 濃 度が年々減少しているのに対して, $\mathrm{SO}_{2}(\mathrm{~g})$ 濃度は2011〜 2013年度に増加し, 2014～2015年度に再び減少しており， 2011～2013年度に濃度が増加した要因は興味深い。

$\mathrm{nss}^{-} \mathrm{SO}_{4}{ }^{2-}(\mathrm{p})$ 濃度は, 2005年度をピークに減少し, 2013 年度から2014年度にかけて一旦増加したが，その後再び 減少した。 $\mathrm{NH}_{4}^{+}(\mathrm{p})$ 濃度は $\mathrm{nss}^{-} \mathrm{SO}_{4}{ }^{2-}(\mathrm{p})$ 濃度とよく似た変化 であった。

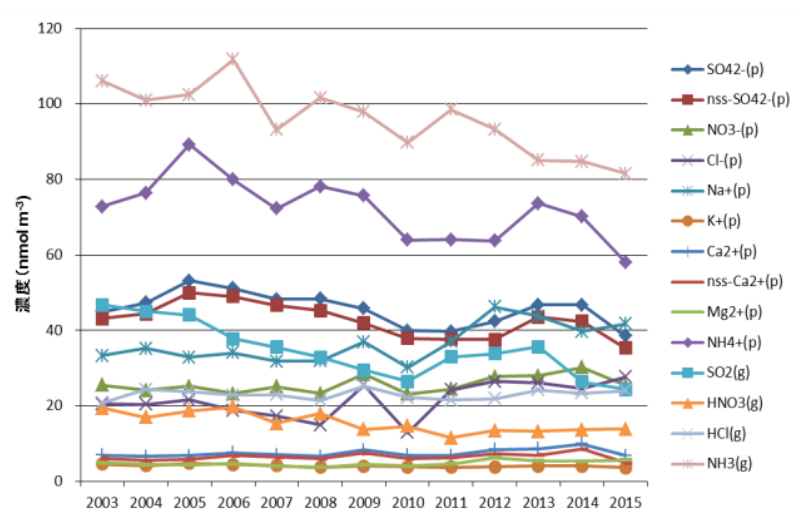

図5.2.9 ガス状および粒子状成分の 全国中央値の経年変化 
表5.2.4 ガス状および粒子状成分の全国中央値 $\left(\mathrm{nmol} \mathrm{m}^{-3}\right)$

\begin{tabular}{|c|c|c|c|c|c|c|c|c|c|c|c|c|c|}
\hline & 2003 & 2004 & 2005 & 2006 & 2007 & 2008 & 2009 & 2010 & 2011 & 2012 & 2013 & 2014 & 2015 \\
\hline $\mathrm{SO}_{4}{ }^{2-}(\mathrm{p})$ & 45.0 & 47.3 & 53.2 & 51.1 & 48.3 & 48.4 & 45.8 & 39.9 & 39.7 & 42.4 & 46.7 & 46.7 & 38.5 \\
\hline $\mathrm{nss}^{-\mathrm{SO}_{4}{ }^{2-}(\mathrm{p})}$ & 43.2 & 44.4 & 50.0 & 49.0 & 46.7 & 45.2 & 41.9 & 37.9 & 37.7 & 37.5 & 43.5 & 42.3 & 35.4 \\
\hline $\mathrm{NO}_{3}^{-}(\mathrm{p})$ & 25.5 & 24.1 & 25.2 & 23.3 & 25.1 & 23.3 & 28.4 & 23.1 & 24.4 & 27.8 & 28.0 & 30.2 & 25.4 \\
\hline $\mathrm{Cl}^{-}(\mathrm{p})$ & 20.5 & 20.3 & 21.6 & 18.8 & 17.3 & 14.9 & 25.5 & 12.9 & 24.2 & 26.5 & 26.0 & 24.6 & 27.6 \\
\hline $\mathrm{Na}^{+}(\mathrm{p})$ & 33.3 & 35.2 & 32.9 & 34.1 & 31.8 & 31.9 & 36.9 & 30.2 & 37.1 & 46.3 & 43.8 & 39.7 & 41.8 \\
\hline $\mathrm{K}^{+}(\mathrm{p})$ & 4.6 & 4.2 & 4.8 & 4.5 & 4.2 & 3.8 & 4.0 & 3.8 & 3.7 & 3.9 & 4.1 & 4.1 & 3.6 \\
\hline $\mathrm{Ca}^{2+}(\mathrm{p})$ & 7.0 & 6.6 & 6.8 & 7.6 & 7.1 & 6.7 & 8.3 & 7.0 & 6.9 & 8.5 & 8.7 & 10.0 & 6.8 \\
\hline $\mathrm{nss}^{-} \mathrm{Ca}^{2+}(\mathrm{p})$ & 6.1 & 5.6 & 5.8 & 6.8 & 6.4 & 6.0 & 7.4 & 6.0 & 6.3 & 7.3 & 6.9 & 8.5 & 4.9 \\
\hline $\mathrm{Mg}^{2+}(\mathrm{p})$ & 4.9 & 4.5 & 4.4 & 4.7 & 4.1 & 3.8 & 4.5 & 4.1 & 4.6 & 6.3 & 5.4 & 5.3 & 5.6 \\
\hline $\mathrm{NH}_{4}{ }^{+}(\mathrm{p})$ & 72.8 & 76.4 & 89.2 & 80.0 & 72.3 & 78.1 & 75.6 & 64.0 & 64.1 & 63.7 & 73.6 & 70.2 & 58.1 \\
\hline $\mathrm{SO}_{2}(\mathrm{~g})$ & 46.8 & 45.0 & 44.0 & 37.8 & 35.5 & 32.9 & 29.5 & 26.4 & 33.0 & 33.8 & 35.6 & 26.4 & 24.4 \\
\hline $\mathrm{HNO}_{3}(\mathrm{~g})$ & 19.4 & 17.0 & 18.7 & 19.8 & 15.4 & 17.9 & 13.8 & 14.7 & 11.6 & 13.5 & 13.3 & 13.6 & 13.9 \\
\hline $\mathrm{HCl}(\mathrm{g})$ & 20.8 & 24.4 & 23.8 & 22.8 & 23.0 & 21.5 & 25.3 & 22.2 & 21.6 & 21.9 & 24.3 & 23.3 & 24.0 \\
\hline $\mathrm{NH}_{3}(\mathrm{~g})$ & 106.1 & 100.9 & 102.5 & 111.8 & 93.2 & 101.6 & 97.9 & 89.7 & 98.6 & 93.3 & 85.1 & 84.7 & 81.6 \\
\hline 調査地点数 & 28 & 32 & 30 & 26 & 22 & 27 & 27 & 28 & 32 & 32 & 34 & 26 & 30 \\
\hline
\end{tabular}
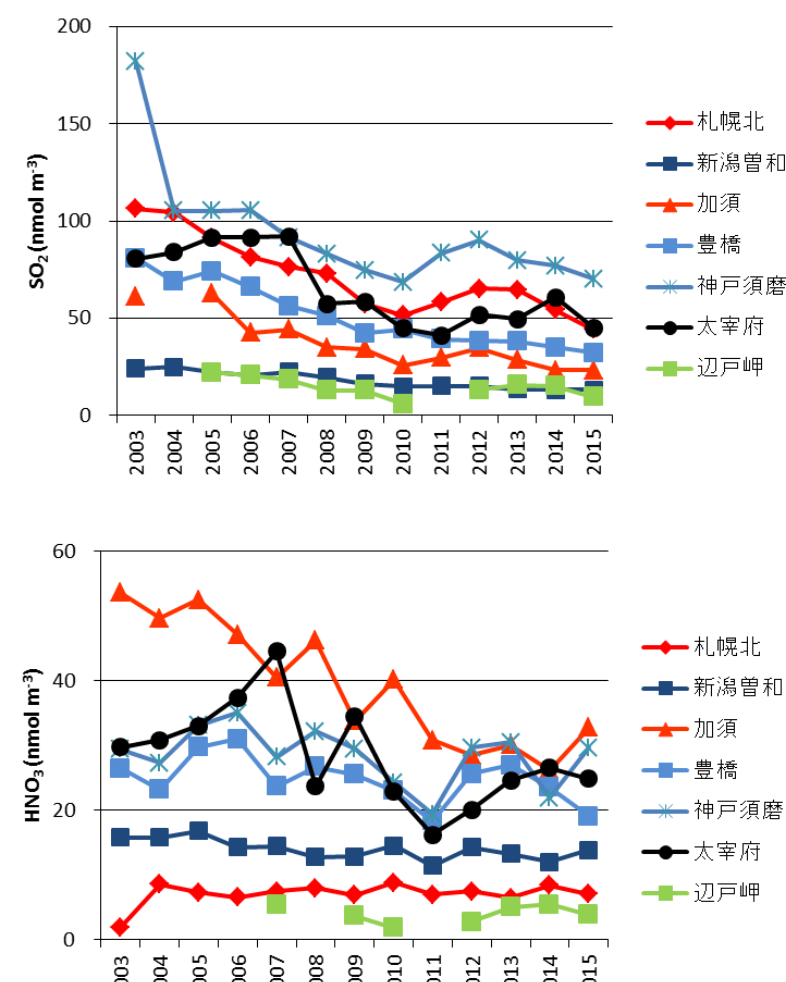

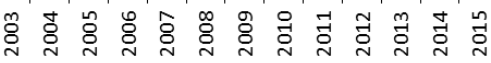

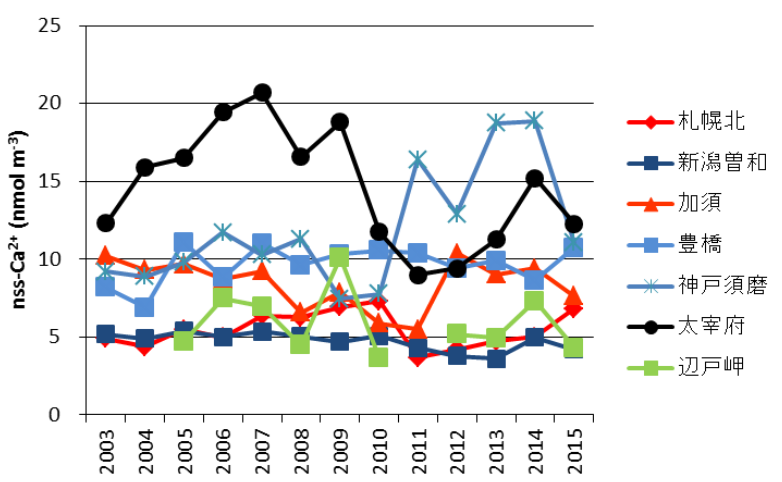

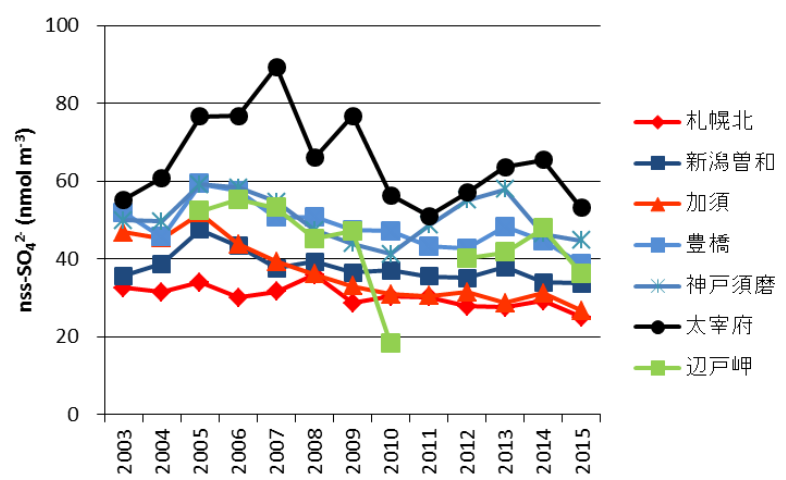

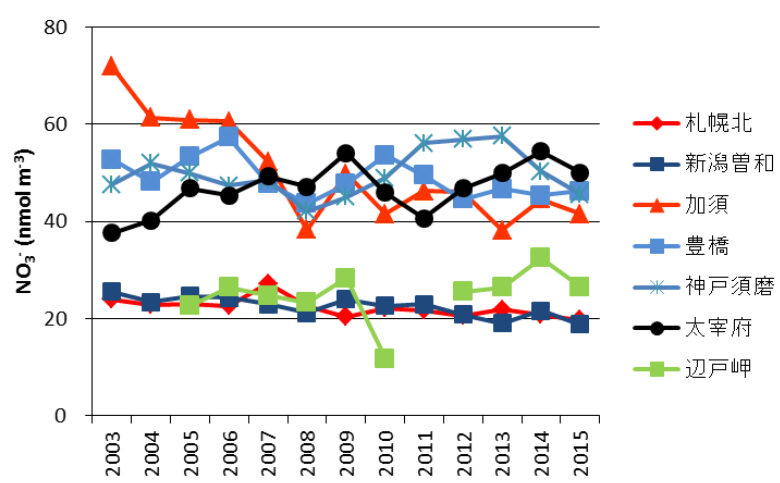

図5.2.10 ガス状および粒子状成分の年平均濃度の経年変化 
$\mathrm{Na}^{+}(\mathrm{p})$ やCl- $(\mathrm{p})$ 濃度は, 2003〜2008年度と比べて, 2011 年度以降に濃度が高くなる傾向を示した。 $\mathrm{Mg}^{2+}(\mathrm{p})$ 濃度も 同様の増加傾向がみられることから, 海塩粒子の影響が 考えられる。海塩粒子の増加の要因は, 台風の影響や海 岸に近い千葉県の観測地点が増えたことが関係すると考 えられる。

$\mathrm{nss}^{-} \mathrm{Ca}^{2+}(\mathrm{p})$ や $\mathrm{NO}_{3}{ }^{-}(\mathrm{p})$ 濃度は微増傾向がみられており， 黄砂および黄砂とともに運ばれる大気污染物質の影響を 受けている可能性がある。

これらの濃度の経年変化には, 発生源の状況や気象状 況, 降水量など様々な要因が複雑に絡んでいると考えら れる。そこで, 経年変化の地域特性を明らかにするために, 既報 ${ }^{13)}$ と同様の7地点 (札幌北, 新潟兽和, 加須, 豊橋, 神 戸須磨，太宰府，辺戸岬)について $\mathrm{SO}_{2}(\mathrm{~g}), \mathrm{nss}^{-} \mathrm{SO}_{4}{ }^{2-}(\mathrm{p})$ ， $\mathrm{HNO}_{3}(\mathrm{~g}), \mathrm{NO}_{3}{ }^{-}(\mathrm{p}), \mathrm{nss}^{-} \mathrm{Ca}^{2+}(\mathrm{p})$ 濃度の経年変化 (年平均值) を示したものが図5.2.10である。辺戸岬では2005年度よ り調査を行っている。

$\mathrm{SO}_{2}(\mathrm{~g})$ 濃度は, 神戸須磨, 札幌北, 太宰府で高く, 辺 戸岬や新潟曽和で低かった。太宰府以外の $\mathrm{SO}_{2}(\mathrm{~g})$ 濃度は 2003年度から2015年度にかけて減少傾向を示した。太宰 府では，2007年度まではやや増加傾向で, それ以降は減 少傾向に転じているようにみえる。どの地点も，2011〜 2013年度に増加しているが，その後は減少した。

$\mathrm{nss}^{-} \mathrm{SO}_{4}{ }^{2-}(\mathrm{p})$ 濃度は, 太宰府で最も高く, 札幌北で最も 低くなり, 東へ行くほど濃度は低下する傾向がみられた。 2003 2011年度までの $\mathrm{nss}^{-} \mathrm{SO}_{4}{ }^{2-}$ (p) 濃度は, 太宰府と辺戸 岬以外の地点では2005年度まで増加しその後減少, 太宰 府と辺戸岬では2006年度または2007年度まで増加しその 後減少した。このように，地点によって若干異なるが， $\mathrm{nss}^{-} \mathrm{SO}_{4}{ }^{2-}(\mathrm{p})$ 濃度は2005 2007年度までは増加傾向, それ 以降は減少傾向がみられた。Lu et al. (2010) ${ }^{15)}$ や大原 (2012) ${ }^{16)}$ は，2000年以降増加傾向にあった中国における $\mathrm{SO}_{2}$ 排出量が2006年頃を境に減少したことを報告しており， 中国における $\mathrm{SO}_{2}$ 排出量の経年変化と本調査で得られた $\mathrm{nss}^{-} \mathrm{SO}_{4}{ }^{2-}(\mathrm{p})$ 濃度の経年変化とはよく似ている。このこと は, 日本の $\mathrm{nss}^{-} \mathrm{SO}_{4}{ }^{2-}(\mathrm{p})$ 濃度はアジア大陸から排出される $\mathrm{SO}_{2}$ の影響を強く受けていることを示唆する。2011年度か ら2013～2014年度までの増加の原因については不明であ るが, 今後は, 中国等の $\mathrm{SO}_{2}$ 排出量の推移に注視するとと もに，桜島・霧島等の火山や船舶など国内発生源の影響 についても検討する必要があろう。

$\mathrm{HNO}_{3}(\mathrm{~g})$ 濃度は, 加須や太宰府で高く, 辺戸岬や札幌 北で低かった。太宰府の経年変化ははっきりしないが, 加須, 豊橋および神戸須磨では減少傾向, 新潟曽和, 札 幌北および辺戸岬では横ばいであった。 $\mathrm{NO}_{3}^{-}{ }^{-}(\mathrm{p})$ 濃度は, 加須, 豊橋, 神戸須磨, 太宰府で高く, 新潟兽和, 札幌 北, 辺戸岬で低かった。 $\mathrm{NO}_{3}{ }^{-}(\mathrm{p})$ 濃度は, 加須では減少傾
向，太宰府と辺戸岬ではやや増加傾向が見られるが，他 の地点では横ばいであった。太宰府と辺戸岬の $\mathrm{NO}_{3}^{-}(\mathrm{p})$ 濃 度の増加傾向は中国の $\mathrm{NO}_{\mathrm{x}}$ 排出量の増加傾向 ${ }^{16)}$ と似てお り興味深い。 $\mathrm{HNO}_{3}$ は水に溶けやすく大気中から除去され やすいため $\mathrm{SO}_{2}$ と比べて長距離輸送されにくいと考えら れるが，太宰府や辺戸岬の $\mathrm{NO}_{3}{ }^{-}(\mathrm{p})$ は $\mathrm{SO}_{2}(\mathrm{~g})$ や $\mathrm{nss}^{-} \mathrm{SO}_{4}{ }^{2-}(\mathrm{p})$ と同様にアジア大陸の影響を受けている可能性がある。 $\mathrm{nss}^{-} \mathrm{Ca}^{2+}(\mathrm{p})$ 濃度は, 太宰府や神戸須磨で高く, 新潟曽 和で低かった。 $\mathrm{nss}^{-} \mathrm{Ca}^{2+}(\mathrm{p})$ 濃度は年によって変動が大き いが, 太宰府は2007年度以降に減少傾向, 神戸須磨は2011 年度以降に増加傾向がみられた。加須は2003年度から 2011年度にかけて減少したが，2012年度以降はやや高い 濃度で推移している。 $\mathrm{nss}^{-} \mathrm{Ca}^{2+}(\mathrm{p})$ 濃度の変動は, 黄砂や 地域的污染の影響が考えられる。

\section{一 引用文献 -}

1）環境省：平成27年度酸性雨調査結果について, http://www. env. go. jp/air/acidrain/monitoring/h27 /index. html

2）全国環境研協議会 酸性雨調查研究部会: 第3次酸性 雨全国調査結果，全国環境研会誌，28，126-196，2003

3) Acid Deposition Monitoring Network in East Asia : 東アジアにおけるフィルターパック法に関する技術 資料, http://www. eanet. cc/jpn/docea_f. html

4）全国環境研協議会 酸性雨広域大気污染調査研究部 会 : 第5次酸性雨全国調査報告書（平成26年度）, 全国 環境研会誌，41(3)，2-37，2016

5) M. Aikawa, T. Hiraki, M. Yamagami, M. Kitase, Y. Nishikawa, I. Uno: Regionality and particularity of a survey site form the viewpoint of the $\mathrm{SO}_{2}$ and $\mathrm{SO}_{4}{ }^{2-}$ concentrations in ambient air in a $250-\mathrm{km} \times 250-\mathrm{km}$ region of Japan, Atmos. Environ., 42, 1389-1398, 2008

6）気象庁: 予報用語, http://www. jma. go. jp/ jma/kishou/know/yougo_hp/mokuji.html

7）気象庁：年間の日本の主な火山活動, http://www. data. jma. go. jp/svd/vois/data/tokyo/ST OCK/monthly_v-act_doc/annual.htm

8）気象庁：[地球環境のデータバンク]黄砂, http:// www. data. jma. go.jp/gmd/env/kosahp/kosa_data_inde x. html

9）環境省：環境大気常時監視マニュアル（第6版）

10) T. Ohara, H. Akimoto, J. Kurokawa, N. Horii, K. Yamaji, X. Yan, T. Hayasaka: An Asian emission inventory of anthropogenic emission source for the period 1980-2020, Atmos. Chem. Phys., 7, 4419-4444, 2007 
11）全国環境研協議会 酸性雨調査研究部会: 第4次酸 性雨全国調査報告書(平成18年度), 全国環境研会誌, 33, 126-196, 2008

12）全国環境研協議会 酸性雨調查研究部会: 第4次酸 性雨全国調查報告書 (平成22年度), 全国環境研会誌,

37, 110-158, 2012

13）全国環境研協議会 酸性雨調査研究部会: 第5次酸 性雨全国調査報告書 (平成24年度), 全国環境研会誌,

39, 100-145, 2014
14）環境省：環境白書 循環型社会白書/生物多様性白 書（平成28年版），p. 424，2016

15) Z. Lu, D. G. Streets, Q. Zhang, S. Wang, G. R. Carmichae1, Y. F. Cheng, C. Wei, M. Chin, T. Dieh1, Q. Tan: Sulfur dioxide emissions in China and sulfur trends in East Asia since 2000, Atmos. Chem. Phys., 10, 6311-6331, doi:10.5194/acp- 10-6311- 2010, 2010

16）大原利眞:東アジアにおける広域越境大気污染モデ リングの最新動向, 水環境学会誌, 35, 6-9, 2012 


\section{3 乾性沈着量の推計}

\subsection{1 乾性沈着推計ファイル}

インファレンシャル法による乾性沈着量の推計を行っ た。インファレンシャル法は気象データなどから沈着速 度 $\left(V_{d}\right)$ を算出し, 乾性沈着量を求める方法である ${ }^{1)} 。$

このモデルは以下の式で表される。

$\mathrm{F}=\mathrm{V}_{\mathrm{d}}(\mathrm{z}) \times \mathrm{C}$

$\mathrm{F}$ : 沈着面への沈着物質のフラックス (沈着量)

$\mathrm{V}_{\mathrm{d}}(\mathrm{z})$ ：基準高さ $\mathrm{z}$ における沈着速度

$C:$ 沈着物質の大気中濃度

したがって， $\mathrm{V}_{\mathrm{d}}$ が決定されれば，大気中の物質濃度か ら乾性沈着量が求められる。 $V_{d}$ は沈着成分の輸送されや すさ, 沈着しやすさによって変化し, 風速や気温などの 気象データ, また対象成分の溶解度や地表面の被覆状況 (土地利用状況)などから推定する。

$V_{\mathrm{d}}$ の算出には，野口らが表計算ソフト (MS Exce1)のフ アイルとして開発した乾性沈着推計ファイルVer. 4-2を 用いた ${ }^{2)}$ 。このファイルは, 北海道立総合研究機構環境 科学研究センターのHPで公開されており ${ }^{3)}$, ダウンロー ドが可能である。ファイルの詳細についてはそちらを参 照していただきたい。

この乾性沈着推計ファイルは, 現在も改良が続けられ ているため, 今回用いたVer.4-2による計算は, 過去に 報告した計算結果と必ずしも一致しない。また，乾性沈 着推計ファイルVer. 4-2では, 市街地の粒子状物質のVd に上限值が設定されているが本報告では上限值を外し て計算した。

\section{3.2 乾性沈着量の推計方法}

乾性沈着量の推計はFP法で大気濃度の測定を実施し た31地点について実施した。また，FP法調査地点のうち 自動測定機またはパッシブ法で $\mathrm{NO}_{2}, \mathrm{NO}$ 測定を実施した 17 地点は $\mathrm{NO}_{2}, \mathrm{NO}$ てつても推計した。

$\mathrm{V}_{\mathrm{d}}$ の算出において, 乾性沈着推計ファイルに入力する 気象データ(風速, 気温, 湿度, 日射量, 雲量) は, 調査 実施機関が指定する各調査地点に近い気象官署, アメダ $\boldsymbol{X}^{4)}$ ，大気污染常時監視測定局の1時間值を用いた。

季節区分 (春, 夏, 秋, 冬 (積雪なし), 冬 (積雪あり))
は，温量指数と季節区分指標を用いる方法とした。

$\mathrm{V}_{\mathrm{d}}$ は表面の状況により異なるため, 土地利用状況別に, 粒子状物質 $\left(\mathrm{SO}_{4}{ }^{2-}, \mathrm{NO}_{3}{ }^{-}, \mathrm{NH}_{4}^{+}\right.$, 以後 $(\mathrm{p})$ をつけて表示) お よびガス状物質 $\left(\mathrm{SO}_{2}, \mathrm{HNO}_{3}, \mathrm{NH}_{3}\right.$, 以後 $(\mathrm{g})$ をつけて表示, $\left.\mathrm{NO}, \mathrm{NO}_{2}\right)$ の $\mathrm{V}_{\mathrm{d}}$ それぞれ算出した。

各調査地点で対象成分ごとに算出した土地利用状況 別 $V_{d}\left(\mathrm{~cm} \mathrm{~s}^{-1}\right)$ の年平均值を参考として表5.3.1に示す。

乾性沈着量は, 土地利用状況別 $\mathrm{V}_{\mathrm{d}}$ を調查地点周辺の土 地利用割合で加重平均し, 大気濃度との積を求めた。環 境省の越境大気污染・酸性雨長期モニタリング報告書 (平成20～24年度 $)^{5)}$ では, 測定局周辺約 $1 \mathrm{~km}$ の森林と草地 の利用割合で計算されているが, 本報告書では, 測定局 周辺半径約 $20 \mathrm{~km}$ 推計対象として, 土地利用の分類を市 街地 (建物用地, 幹線交通用地, その他), 森林地域 (森 林), 農地 (田, その他の農用地), 草地 (ゴルフ場などの 草地, 荒地), 水面(河川および湖沼, 海浜)とした。土 地利用状況によって $\mathrm{V}_{\mathrm{d}}$ が大きく異なるため(表5.3.1)， 土地利用の割合は推計結果に大きな影響を及ぼす。市街 地の $V_{\mathrm{d}}$ 推計のためのパラメーターについては十分に検 証が行われていないなど不確実な部分が大きいが, 本調 査では市街地にある測定地点が多いことからこの条件 設定とした。また, 気象データの測定点が, FP法の測定 地点と異なる地点が多いことから半径 $20 \mathrm{~km}$ とた。土地 利用割合は国土地理院のデータ ${ }^{6)}$ か 5 F法の測定地点周 辺の海を除く半径 $20 \mathrm{~km}$ にかかるメッシュ值を抽出して 求めた。最多頻度の季節が冬 (積雪あり) となった月につ いては, 農地, 草地の $\mathrm{V}_{\mathrm{d}}$ の代わりに, 積雪の $\mathrm{V}_{\mathrm{d}}$ を推計に 用いた。なお, これらの条件設定については, さらに検 討が必要である。

大気濃度はFP法で測定した $\mathrm{nss}^{-} \mathrm{SO}_{4}{ }^{2-}(\mathrm{p}), \mathrm{NO}_{3}{ }^{-}(\mathrm{p})$ ， $\mathrm{NH}_{4}^{+}(\mathrm{p}), \mathrm{SO}_{2}(\mathrm{~g}), \mathrm{HNO}_{3}(\mathrm{~g}), \mathrm{NH}_{3}(\mathrm{~g})$, 自動測定機またはパ ッシブ法で測定した $\mathrm{NO}_{2}, \mathrm{NO}$ 月月平均濃度を用いた。月 ごとに乾性沈着量を求め, それらを合計して年間乾性沈 着量を算出した。

FP法では粒子状物質とガス状物質の完全な分別捕集は 難しい。しかし，乾性沈着ではガス状物質と粒子状物質 の沈着速度が異なるため, FP法で得られた $\mathrm{HNO}_{3}(\mathrm{~g})$ と $\mathrm{NO}_{3}^{-}(\mathrm{p}), \mathrm{NH}_{3}(\mathrm{~g})$ と $\mathrm{NH}_{4}^{+}(\mathrm{p})$ 濃度を用いて乾性沈着量を算出

表5.3. 1 土地利用状況別の平均沈着速度 (2015年度)

\begin{tabular}{lrrrrrrrr} 
& \multicolumn{1}{c}{} & & & \multicolumn{2}{c}{ (単位: $\left.\mathrm{cm} \mathrm{s}^{-1}\right)$} \\
\hline & $\mathrm{SO}_{4}{ }^{2-}(\mathrm{p})$ & $\mathrm{NO}_{3}{ }^{-}(\mathrm{p})$ & $\mathrm{NH}_{4}{ }^{+}(\mathrm{p})$ & $\mathrm{SO}_{2}(\mathrm{~g})$ & $\mathrm{HNO}_{3}(\mathrm{~g})$ & $\mathrm{NH}_{3}(\mathrm{~g})$ & $\mathrm{NO}_{2}(\mathrm{~g})$ & $\mathrm{N} 0(\mathrm{~g})$ \\
\hline 市街地 & 0.17 & 0.17 & 0.17 & 0.17 & 4.3 & 0.045 & 0.031 & $4.8 \mathrm{E}-09$ \\
森林地域 & 0.52 & 0.75 & 0.58 & 1.2 & 3.9 & 0.53 & 0.10 & 0.0024 \\
農地 & 0.13 & 0.13 & 0.13 & 0.62 & 1.2 & 0.38 & 0.14 & 0.0020 \\
草地 & 0.16 & 0.16 & 0.16 & 0.66 & 1.6 & 0.35 & 0.10 & 0.0020 \\
積雪 & 0.10 & 0.10 & 0.10 & 0.40 & 0.40 & 0.44 & 0.0014 & 0.00027 \\
水面 & 0.086 & 0.086 & 0.086 & 0.27 & 0.27 & 0.29 & 0.0011 & 0.00022 \\
\hline
\end{tabular}

注）各調查地点で, 対象成分ごとに土地利用別に算出した日沈着速度 $V d\left(\mathrm{~cm} \mathrm{~s}^{-1}\right)$ の年間平均值 
表5.3.2 年間乾性沈着量 (2015年度地点別)

\begin{tabular}{|c|c|c|c|c|c|c|c|c|c|c|c|}
\hline \multirow[t]{2}{*}{ No. } & \multirow[t]{2}{*}{ 都道府県市 } & \multirow[t]{2}{*}{ 地点名 } & $\begin{array}{l}\mathrm{SO}_{2} \\
(\mathrm{~g})\end{array}$ & $\begin{array}{c}\mathrm{HNO}_{3} \\
(\mathrm{~g})\end{array}$ & $\begin{array}{l}\mathrm{NH}_{3} \\
(\mathrm{~g})\end{array}$ & $\begin{array}{c}\mathrm{nss}^{-} \mathrm{SO}_{4}{ }^{2-} \\
(\mathrm{p})\end{array}$ & $\begin{array}{l}\mathrm{SO}_{4}^{2-} \\
(\mathrm{p})\end{array}$ & $\begin{array}{l}\mathrm{NO}_{3}^{-} \\
(\mathrm{p})\end{array}$ & $\begin{array}{c}\mathrm{NH}_{4}^{+} \\
(\mathrm{p})\end{array}$ & $\begin{array}{l}\mathrm{NO}_{2} \\
(\mathrm{~g})\end{array}$ & $\begin{array}{l}\text { N0 } \\
\text { (g) }\end{array}$ \\
\hline & & & \multicolumn{9}{|c|}{$\mathrm{mmol} \mathrm{m} \mathrm{m}^{-2}$} \\
\hline 1 & $\begin{array}{l}\text { 北海道 } \\
\end{array}$ & 利尻 & 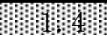 & 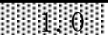 & 3.5 & 1.2 & 1.6 & 1.1 & 1.7 & 197 & 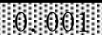 \\
\hline 2 & 北海道 & 札幌北 & 6.1 & 6.7 & 5.4 & 2.1 & 2.2 & 1.8 & 3.5 & 6.5 & 0.016 \\
\hline 3 & 新潟県 & 新潟曾和 & 2.2 & 10.2 & 6.4 & 2.0 & 2.1 & 1.1 & 2.9 & 8.3 & 0.014 \\
\hline 4 & 新潟県 & 長岡 & 3.7 & 13.1 & 11.2 & 3.4 & 3.5 & 2.6 & 6.2 & 6.4 & 0.014 \\
\hline 5 & 新潟市 & 新潟小新 & 2.8 & 10.2 & 6.9 & 2.0 & 2.2 & 1.7 & 2.7 & 8.3 & 0.029 \\
\hline 6 & 群馬県 & 前橋 & 4.2 & 15.2 & 51.1 & 2.1 & 2.2 & 4.1 & 5.7 & 7.8 & 0.027 \\
\hline 7 & 埼玉県 & 加須 & 2.4 & 18.3 & 12.7 & 1.5 & 1.5 & 1.9 & 3.3 & 11.6 & 0.016 \\
\hline 8 & 千葉県 & 旭 & 5.3 & 4.9 & 579.9 & 2.7 & 3.1 & 4.5 & 7.3 & - & - \\
\hline 9 & 千葉県 & 勝浦 & 7.8 & 5.4 & 11.7 & 4.1 & 4.7 & 4.8 & 5.9 & - & - \\
\hline 10 & 千葉県 & 清澄 & 10.5 & 7.7 & 11.5 & 4.7 & 5.2 & 5.3 & 6.8 & - & - \\
\hline 11 & 千葉県 & 市原 & 15.0 & 8.6 & 9.2 & 2.6 & 2.9 & 4. 0 & 3.1 & - & - \\
\hline 12 & 千葉県 & 佐倉 & 5.9 & 15.7 & 10.2 & 2.6 & 2.8 & 2.5 & 3.7 & - & - \\
\hline 13 & 長野県 & 長野 & 3.8 & 17.1 & 13.4 & 3.1 & 3.2 & 1.5 & 5.8 & 5.6 & 0.023 \\
\hline 14 & 静岡県 & 静岡北安東 & 5.7 & 19.9 & 7.5 & 2.7 & 2.8 & 2.7 & 4.5 & - & - \\
\hline 15 & 富山県 & 射水 & 4. 1 & 8.5 & 7.8 & 2.1 & 2.2 & 1.3 & 3.8 & 8.8 & 0.019 \\
\hline 16 & 石川県 & 金沢 & 4.2 & 9.0 & 4.5 & 2.8 & 2.9 & 1.5 & 4.3 & - & - \\
\hline 17 & 福井県 & 福井 & 9.6 & 16.7 & 11.4 & 3.7 & 4.0 & 2.6 & 6.7 & 9.0 & 0.049 \\
\hline 18 & 岐阜県 & 伊自良湖 & 1.5 & 2.0 & 3.3 & mat & 10) & 61) & IItm & - & - \\
\hline 19 & 愛知県 & 豊橋 & 9.4 & 25.0 & 23.7 & 5.3 & 5.6 & 8.1 & 10.8 & 14.9 & 0.047 \\
\hline 20 & 名古屋市 & 名古屋南 & 4.7 & 26.9 & 6.5 & 2.1 & 2.2 & 2.4 & 3.6 & - & - \\
\hline 21 & 和歌山県 & 海南 & 6.0 & 17.3 & 7. 0 & 2.7 & 2.8 & 1.9 & 4.2 & 10.4 & 0.018 \\
\hline 22 & 兵庫県 & 神戸須磨 & 12.1 & 39.5 & 5.4 & 4.9 & 5.3 & 6.0 & 9.4 & - & - \\
\hline 23 & 鳥取県 & 湯梨浜 & 10.1 & 5.8 & 10.9 & 7.2 & 7.7 & 5.7 & 13.8 & 1.4 & 0.062 \\
\hline 24 & 高知県 & 香北 & 1.7 & 5.8 & 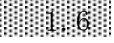 & 2.3 & 2.3 & 0.5 & 3.5 & 1.6 & 0.041 \\
\hline 25 & 福岡県 & 太宰府 & 9.0 & 20.8 & 12.2 & 4.5 & 4.8 & 5.5 & 9.3 & 16.8 & 0.055 \\
\hline 26 & 大分県 & 大分久住 & 14.8 & 9.0 & 6.0 & 3.0 & 3.1 & 1.8 & 5.7 & - & - \\
\hline 27 & 大分県 & 大分 & (14.8) & $(14.0)$ & $(6.2)$ & $(3.4)$ & $(3.5)$ & $(1.9)$ & $(6.1)$ & - & - \\
\hline 28 & 宮崎県 & 宮崎 & 15.5 & 9.5 & 21.7 & 5.6 & 6.0 & 5.6 & 13.2 & - & - \\
\hline 29 & 鹿児島県 & 鹿児島 & 20.7 & 10.4 & 13.4 & 3.3 & 3.6 & 3.3 & 7.0 & - & - \\
\hline 30 & 沖縄県 & 大里 & 3.4 & 8.3 & 27.4 & 4.2 & 5.0 & 3.4 & 4.8 & 1.5 & 0.005 \\
\hline \multirow[t]{5}{*}{31} & 沖縄県 & 辺戸岬 & 6.2 & 7.1 & 7.3 & 10.5 & 14.9 & 11.0 & 9.9 & 1.1 & 0.002 \\
\hline & & 最低值 & 1.4 & 1.0 & 1.6 & 0.6 & 0.7 & 0.2 & 1.1 & 0.6 & 0.001 \\
\hline & & 最高値 & 20.7 & 39.5 & 579.9 & 10.5 & 14.9 & 11.0 & 13.8 & 16. 8 & 0.062 \\
\hline & & 中央値 & 5.8 & 9.8 & 9.7 & 2.7 & 3.0 & 2.6 & 5.2 & 7.8 & 0.019 \\
\hline & & 平均値 & 7.0 & 12.5 & 30.4 & 3.4 & 3.8 & 3.3 & 5.8 & 7.1 & 0.026 \\
\hline
\end{tabular}

注）全国最低值は網掛け，全国最高值は白抜きで示した。参考値は（）で示した。

している。そのため, これらの乾性沈着量はFP法におけ るアーティファクトの影響を受けている可能性がある。

\subsection{3 乾性沈着量の推計結果}

各地点の年間乾性沈着量の推計結果は表5.3.2のとお り。乾性沈着量はFP法で測定した大気濃度の年平均值が 欠測または参考值となった調査地点を除いて評価した。 ガス状物質の乾性沈着量は， $\mathrm{SO}_{2}(\mathrm{~g})$ が 1.4 (利尻) 〜 20.7 (鹿児島) (平均值7.0) $\mathrm{mmol} \mathrm{m}^{-2} \mathrm{y}^{-1}, \mathrm{HNO}_{3}$ (g) が1.0 (利尻) 39. 5 (神戸須磨) (平均值12.5) $\mathrm{mmol} \mathrm{m}^{-2} \mathrm{y}^{-1}$, $\mathrm{NH}_{3}(\mathrm{~g})$ が1.6 (香北) 579.9 (旭) (平均值 30.4 ) $\mathrm{mmol} \mathrm{m}^{-2} \mathrm{y}^{-1}$ だった。

粒子状物質の乾性沈着量は, $\mathrm{nss}^{-} \mathrm{SO}_{4}{ }^{2-}$ ( $\mathrm{p}$ ) が 0.6 (伊自 良湖) 10.5 (辺戸岬) (平均値3.4) $\mathrm{mmol} \mathrm{m}^{-2} \mathrm{y}^{-1}, \mathrm{NO}_{3}^{-}(\mathrm{p})$ が 0.2 (伊自良湖) 11.0 (辺戸岬) (平均值 3.3 ) $\mathrm{mmol} \mathrm{m}^{-2} \mathrm{y}^{-1}$, $\mathrm{NH}_{4}^{+}(\mathrm{p})$ が1.1(伊自良湖) 13.8 (湯梨浜) (平均值5. 8) mmol m $\mathrm{m}^{-2} \mathrm{y}^{-1}$ だった。

ガス状物質と粒子状物質を合わせた乾性沈着量は, 非 海塩由来硫黄成分 $\left(\mathrm{SO}_{2}(\mathrm{~g})+\mathrm{nss}^{-} \mathrm{SO}_{4}{ }^{2-}(\mathrm{p})\right)$ が 2.1 (伊自良 湖) 23.9 (鹿児島) (平均值10.4) $\mathrm{mmol} \mathrm{m}^{-2} \mathrm{y}^{-1}, \mathrm{NO}_{\mathrm{x}}\left(=\mathrm{NO}_{2}\right.$ $+\mathrm{NO})$ を含まない酸化態窒素成分 $\left(\mathrm{HNO}_{3}(\mathrm{~g})+\mathrm{NO}_{3}-(\mathrm{p})\right)$ が 2.1 (利尻) 45. 5 (神戸須磨) (平均值 15.9 ) mmol m $\mathrm{m}^{-2} \mathrm{y}^{-1}$, 還元態窒素成分 $\left(\mathrm{NH}_{3}(\mathrm{~g})+\mathrm{NH}_{4}+(\mathrm{p})\right)$ が4. 4 (伊自良湖) 587.2 (旭) (平均値 36.2 ) $\mathrm{mmol} \mathrm{m}^{-2} \mathrm{y}^{-1}$ だった。

$\mathrm{NO}_{\text {x }}$ 測定地点の $\mathrm{NO}_{2}$ の乾性沈着量は 0.6 (利尻) 16.8 (太宰府) (平均值7.1) $\mathrm{mmol} \mathrm{m}^{-2} \mathrm{y}^{-1}$, N0の乾性沈着量は 0.001 (利尻) 0.062 (湯梨浜) (平均值0.026) $\mathrm{mmol} \mathrm{m}^{-2} \mathrm{y}^{-1}$ だった。酸化態窒素成分に $\mathrm{NO}_{\mathrm{x}}$ を加えた窒素酸化物成分

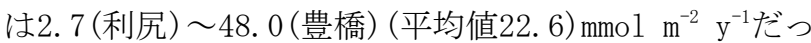
た。 


\subsection{4 乾性沈着量と湿性沈着量との比較}

湿性沈着およびFP法による大気濃度の年平均值が全 て有効となった 28 地点について, 湿性沈着 (以後 (wet) をつけて表示) と乾性沈着を合わせた総沈着量を図5.3.1 に示す。ここで, 総沈着量は, 非海塩由来硫黄成分 $\left(\mathrm{SO}_{2}\right.$ $\left.(\mathrm{g}), \mathrm{nss}^{-} \mathrm{SO}_{4}{ }_{4}{ }^{2-}(\mathrm{p}), \mathrm{nss}^{-} \mathrm{SO}_{4}{ }^{2-}(\mathrm{wet})\right)$, 酸化態窒素成分 $\left(\mathrm{HNO}_{3}(\mathrm{~g}), \mathrm{NO}_{3}^{-}(\mathrm{p}), \mathrm{NO}_{3}^{-}(\mathrm{wet})\right)$ および還元態窒素成分 $\left(\mathrm{NH}_{3}(\mathrm{~g}), \mathrm{NH}_{4}{ }^{+}(\mathrm{p}), \mathrm{NH}_{4}{ }^{+}(\mathrm{we} t)\right)$ に分類して考察した。また, $\mathrm{NO}_{\mathrm{x}}$ の乾性沈着量は, $\mathrm{NO}_{2}$ の乾性沈着量の年平均值が有効 となった 17 地点について酸化態窒素成分と合わせて示 した。

総沈着量の年間値は, 非海塩由来硫黄成分が 10.9 (利 尻) 64. 8 (鹿児島) (平均值31.1) $\mathrm{mmol} \mathrm{m}^{-2} \mathrm{y}^{-1}$, 酸化態窒 素成分が 12.5 (利尻) 65.9 (神戸須磨) (平均值 $41.6 \mathrm{~mol}$ $\mathrm{m}^{-2} \mathrm{y}^{-1}$, 還元態窒素成分が 17.0 (香北) 689.3 (旭) (平均 值66.6) $\mathrm{mmol} \mathrm{m}^{-2} \mathrm{y}^{-1}$ だった。 $\mathrm{NO}_{\mathrm{x}}$ の乾性沈着量を含めた酸 化態窒素成分は13.1 (利尻) 78.3 (太宰府) (平均值

49. 3) $\mathrm{mmol} \mathrm{m}^{-2} \mathrm{y}^{-1}$ だった。

総沈着量に占める乾性沈着量の比率 (=乾性沈着量/ (乾性沈着量 + 湿性沈着量 $) \times 100(\%))$ は, 非海塩由来硫 黄成分が $8 \%$ (伊自良湖) 58\% (辺戸岬) (平均值 $33 \%$ ), 酸化
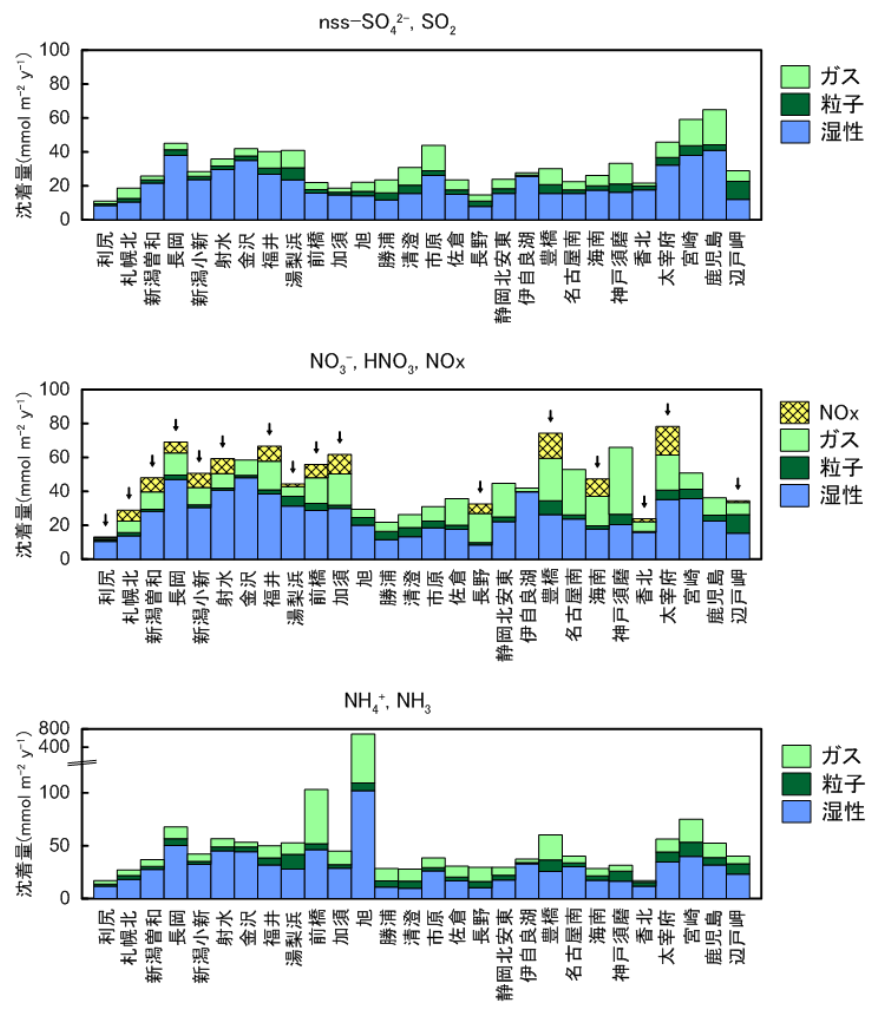

\section{図5.3.1 調査地点の年沈着量 (2015年度)}

注) 湿性沈着およびフィルターパック法による対象測定項目の年 間值がすべて有効となった調查地点

注) $\mathrm{NO}_{\mathrm{x}}\left(\mathrm{NO}^{\mathrm{N}} \mathrm{NO}_{2}\right)$ は, 自動測定器または0式パッシブ法による測定地 点の夕表示 (図内 $\downarrow$ 印)
態窒素成分が $5 \%$ (伊自良湖) 69\% (神戸須磨) (平均值39\%)， 還元態窒素成分が $12 \%$ (伊自良湖) $85 \%$ (旭) (平均值 $40 \%$ ) だった。

湿性沈着および大気濃度の年平均值が有効となった 28地点について，6つの地域区分別 (北部 (NJ，2地点), 日本海側 (JS，7), 東部 (EJ, 7), 中央部 (CJ, 7), 西部 (WJ，4), 南西諸島 (SW，1) ) に年間総沈着量の中央値を 図5.3.2に示す。 $\mathrm{NO}_{\mathrm{x}}$ の乾性沈着量についても酸化態窒素 成分に合わせて示した。

総沈着量は, 非海塩由来硫黄成分はWJで, 酸化態窒素 成分はJS, CJ, WJで, 還元態窒素成分はWJ, JS, EJで多 かった。NJでは，いずれの成分の総沈着量も他の地域区 分に比べ少なかった。SWでは, いずれの成分も粒子の乾 性沈着量が他の地域区分に比べ多かった。

中央值から算出した総沈着量に乾性沈着量が占める 割合は, 非海塩由来硫黄成分はSWで, 酸化態窒素成分は CJ, EJ, WJで大きく, 還元態窒素成分はJS, NJで小さか った。

大陸の影響を検討するために, 非海塩由来硫黄成分の 総沈着量と経度を比較した(図5.3.3)。WJは火山の影響 も考えられるが, 全体的にみると大陸に近い経度の小さ
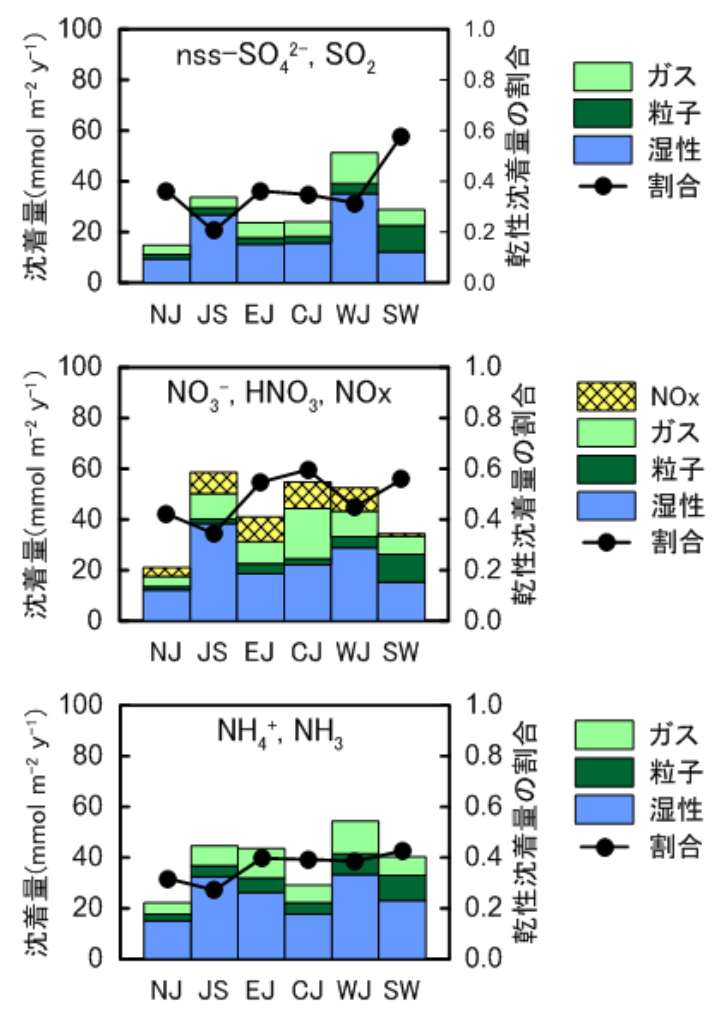

\section{図5.3.2 各地域区分別の年沈着量 (2015年度中央値)}

注) 総沈着量に占める乾性沈着量の比率 = 乾性沈着量 / (乾性沈着量 + 湿性沈着量), 中央値より求めた。 


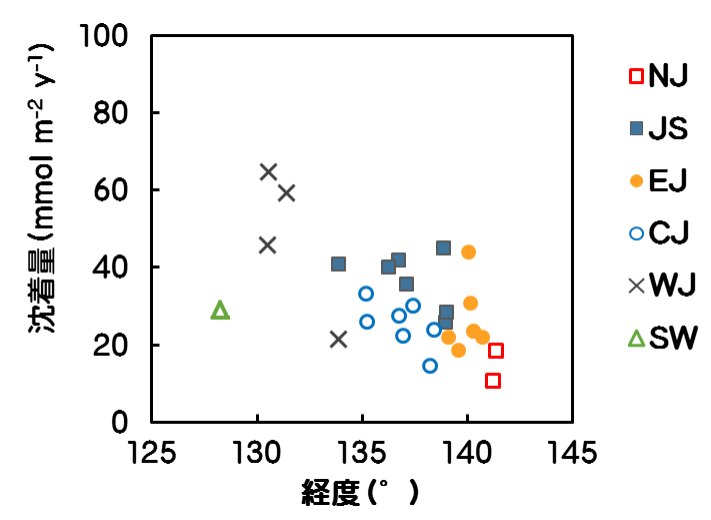

図5.3.3 地域区分別の非海塩由来硫黄成分の 総沈着量と経度の関係

い地点で総沈着量が多くなる傾向がみられた。

\subsection{5 乾性沈着の全無機態窒素沈着量}

土壤の酸性化や湖沼の富栄養化への観点から乾性沈 着量を含む無機態窒素沈着量について検討を行った。た だし, 土壌の酸性化の指標である潜在水素イオン $\left(\mathrm{H}_{\mathrm{eff}}=\right.$ $\mathrm{H}^{+}+2 \mathrm{NH}_{4}^{+}$)については, 大気中の $\mathrm{H}^{+}$を測定していないた め評価できない。そのため湖沼の富栄養化の指標である
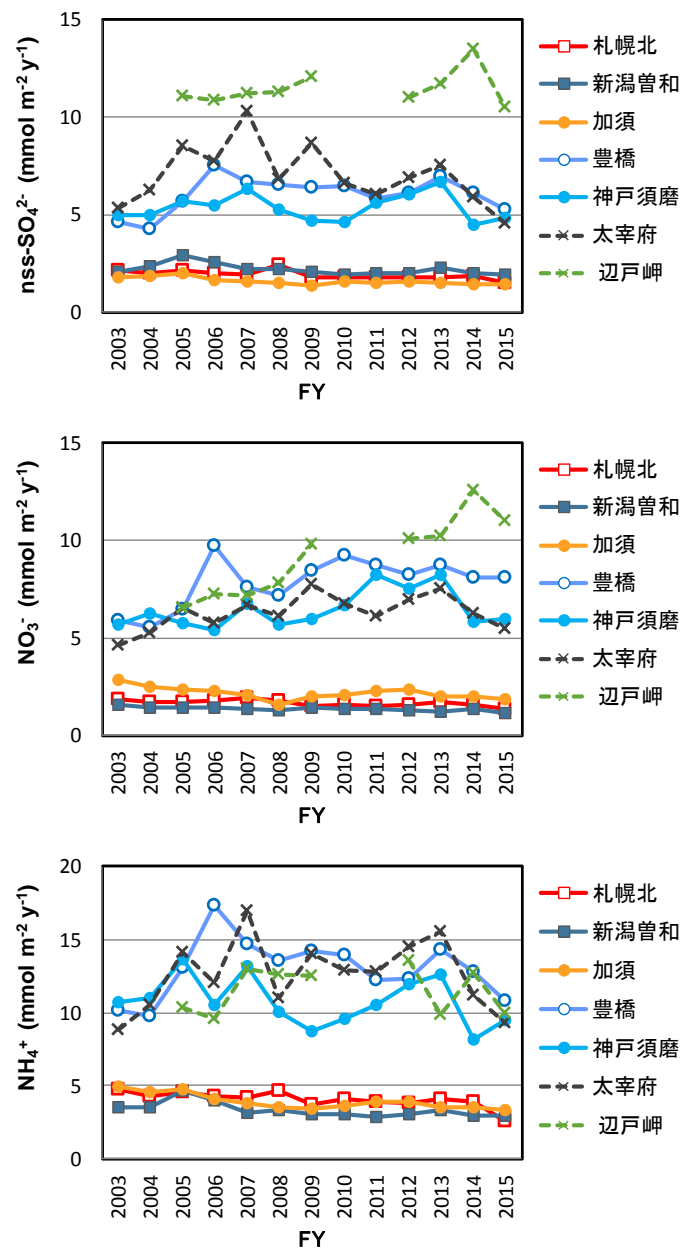

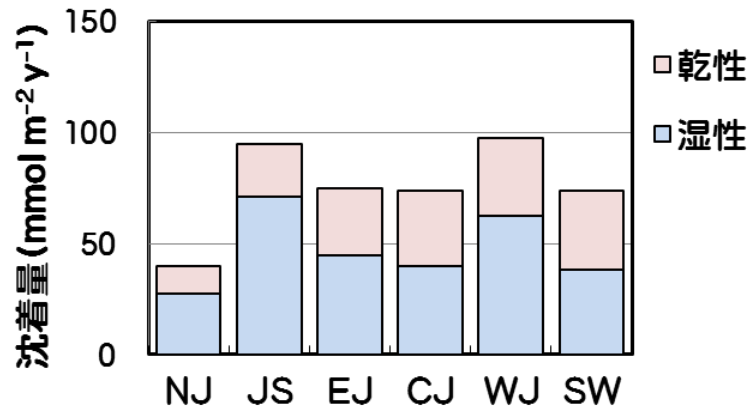

図5.3.4 地域区分別の無機態窒素沈着量 （2015年度中央値）

全無機態窒素 $\left(\Sigma \mathrm{N}=\mathrm{NO}_{3}{ }^{-}+\mathrm{NH}_{4}{ }^{+}\right)$についてのみ検討す ることとした。また, 乾性沈着量についてはガス状成分 の $\mathrm{HNO}_{3}(\mathrm{~g})$ と $\mathrm{NH}_{3}(\mathrm{~g})$ も湖沼に付加すると硝酸イオン, アン モニウムイオンとして寄与すると考えられるので, 粒子 状成分 $\left(\mathrm{NO}_{3}^{-}(\mathrm{p}), \mathrm{NH}_{4}^{+}(\mathrm{p})\right)$ とガス状成分 $\left(\mathrm{HNO}_{3}(\mathrm{~g}), \mathrm{NH}_{3}(\mathrm{~g})\right)$ を含めた全無機態窒素 $\left(\sum \mathrm{N}_{(\mathrm{p}+\mathrm{g})}\right)$ を対象とした。

図5.3.4に湿性沈着およびFP法による大気濃度の年平
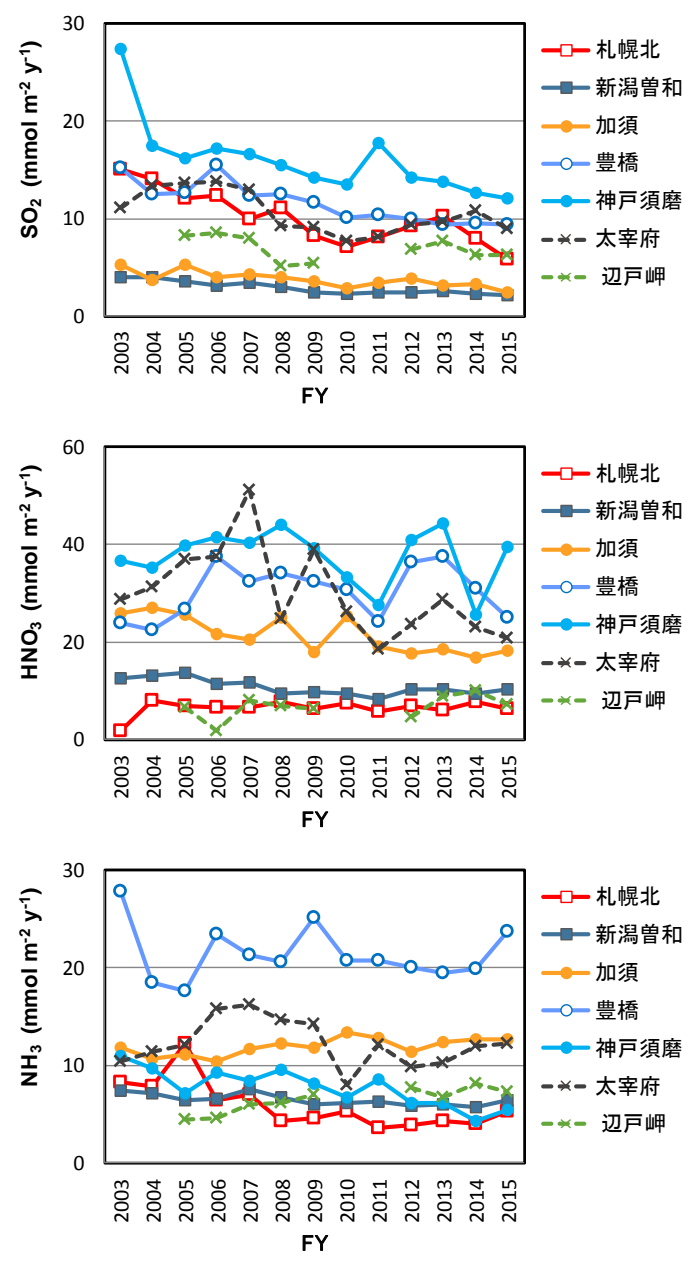

図5.3.5 継続調查地点における乾性沈着量の経年変化 （2003 2015年度） 
均值が全て有効となった地点の, 湿性沈着量および乾性 沈着量の全無機態窒素の地域区分別年間中央值を示す。 湿性沈着量による $\Sigma$ NはJS, WJで, 乾性沈着量による $\sum \mathrm{N}_{(\mathrm{p}+\mathrm{g})}$ はWJ, SWで多かった。 $\sum \mathrm{N}_{(\mathrm{p}+\mathrm{g})}$ は, 湿性沈着量も 含めた全無機態窒素の 2 〜割を占めた。

\subsection{6 乾性沈着量の経年変化}

FP法による大気濃度測定の調查を継続して実施してい る地点のうち, 札幌北, 新潟曽和, 加須, 豊橋, 神戸須 磨, 太宰府, 辺戸岬の7地点について, 2003年度からの乾 性沈着量の経年推移を比較した(図5.3.5)。

粒子状成分の乾性沈着量は, 豊橋, 神戸須磨, 太宰府, 辺戸岬で多く, 札幌北, 新潟曽和, 加須では少ない傾向 がみられた。経年変化をみると, $\mathrm{nss}^{-} \mathrm{SO}_{4}{ }^{2-}(\mathrm{p})$ と $\mathrm{NH}_{4}{ }^{+}(\mathrm{p})$ は, 豊橋と太宰府で2006〜2007年まで増加し，それ以降 横ばいまたは減少に転じる傾向がみられた。 $\mathrm{NO}_{3}^{-}(\mathrm{p})$ は, 豊橋, 神戸須磨, 太宰府, 辺戸岬で増加傾向を示してい たが,この 2 年間は辺戸岬を除き横ばいまたは減少して いる。

ガス状成分の乾性沈着量の経年変化は, 横ばいまたは 減少傾向を示寸地点が多かった。

\section{一 引用文献 -}

1) EANET : Technical Manual on Dry Deposition FluxEstimation in East Asia, http://www. eanet. asia/product/manual/techacm. pdf

2）野口泉, 松田和秀: 乾性沈着ファイルの開発, 北海 道環境科学研究センター所報, 30, 23-28, 20033） 全 国環境研協議会: 第4次酸性雨全国調查報告書 (平成15 年度），全国環境研会誌，30，58-135，2005

3）全国環境研協議会：乾性沈着推計ファイルVer. 4-2, http://www. ies. hro. or. jp/seisakuka/acid_rain/kan seichinchaku/kanseichinchaku. htm

4）（財）気象業務支援センター：気象観測月報2015年3 月-2016年4月，（CD-ROM）

5）環境省：越境大気污染・酸性雨長期モニタリング報 告書 (平成20～24年度)，2014

http://www. env. go. jp/air/acidrain/monitoring/rep 3. html

6）国土交通省国土政策局国土情報課：国土数值情報ダ ウンロードサービス，

http://nlftp.mlit.go. jp/ksj/index. html 


\section{6. パッシブ法によるガス成分濃度}

パッシブ法(以下, PS法) ではフィルターパック法 (以下, FP法)のみでは測定できない $\mathrm{NO}_{2}, \mathrm{NO}_{\mathrm{x}}, \mathrm{O}_{3}$ と, $\mathrm{FP}$ 法と共通 で測定できる $\mathrm{NH}_{3}$ 濃度の測定を行っている。

窒素酸化物 $\left(\mathrm{NO}, \mathrm{NO}_{2}\right)$ では, 排出量の少ない山間部や遠 隔地では常時監視局が極めて少ないが，パッシブサンプ ラーにより濃度情報が得られる。パッシブサンプラーは 誤差や月平均濃度であるなどの課題はあるが, 例えば山 地への全窒素沈着量に対する $\mathrm{NO}, \mathrm{NO}_{2}$ の寄与率を評価に有 用な情報と考えられる。

$0_{3}$ は近年越境大気污染の影響により, 国内の大都市地 域以外の, 郊外や遠隔地でも高濃度が観測されている。 このことから，パッシブサンプラーにより常時監視局の 少ない郊外や遠隔地における $0_{3}$ 濃度を把握することを目 的としている。
$\mathrm{NH}_{3}$ については, FP法ではNH $\mathrm{H}_{3}(\mathrm{~g})$ とアンモニウム塩粒子 $\left(\mathrm{NH}_{4}{ }^{+}(\mathrm{p})\right)$ を分離して測定している。しかしアーティファ クトにより $\mathrm{NH}_{4}{ }^{+}(\mathrm{p})$ の一部が $\mathrm{NH}_{3}(\mathrm{~g})$ に変換されるため, 特 に気温の高い夏期のガス/粒子の比率はアーティファク トの影響を強く受けている1)。一方パッシブサンプラーは 原理的には $\mathrm{NH}_{3}(\mathrm{~g})$ のみを測定できるため, PS法とFP法の 結果と併せることで, より正確なガス/粒子濃度を測定で きる可能性があるとして検討してきた。

測定値について, いずれの項目も定量下限値として EANETにおける定量下限值 $(0.1 \mathrm{ppb})$ を用いた。データの 有効判定はFP法と同様に, 期間適合度 $60 \%$ 以上を有効とし た。測定方法については第4次調查と同様とした ${ }^{2)}$ 。

\section{1 測定地点}

調查地点は大都市, 工業地域, 中小都市域, 田園地域, 森林地域から目的に応じ, 1 地点以上選定することとなっ

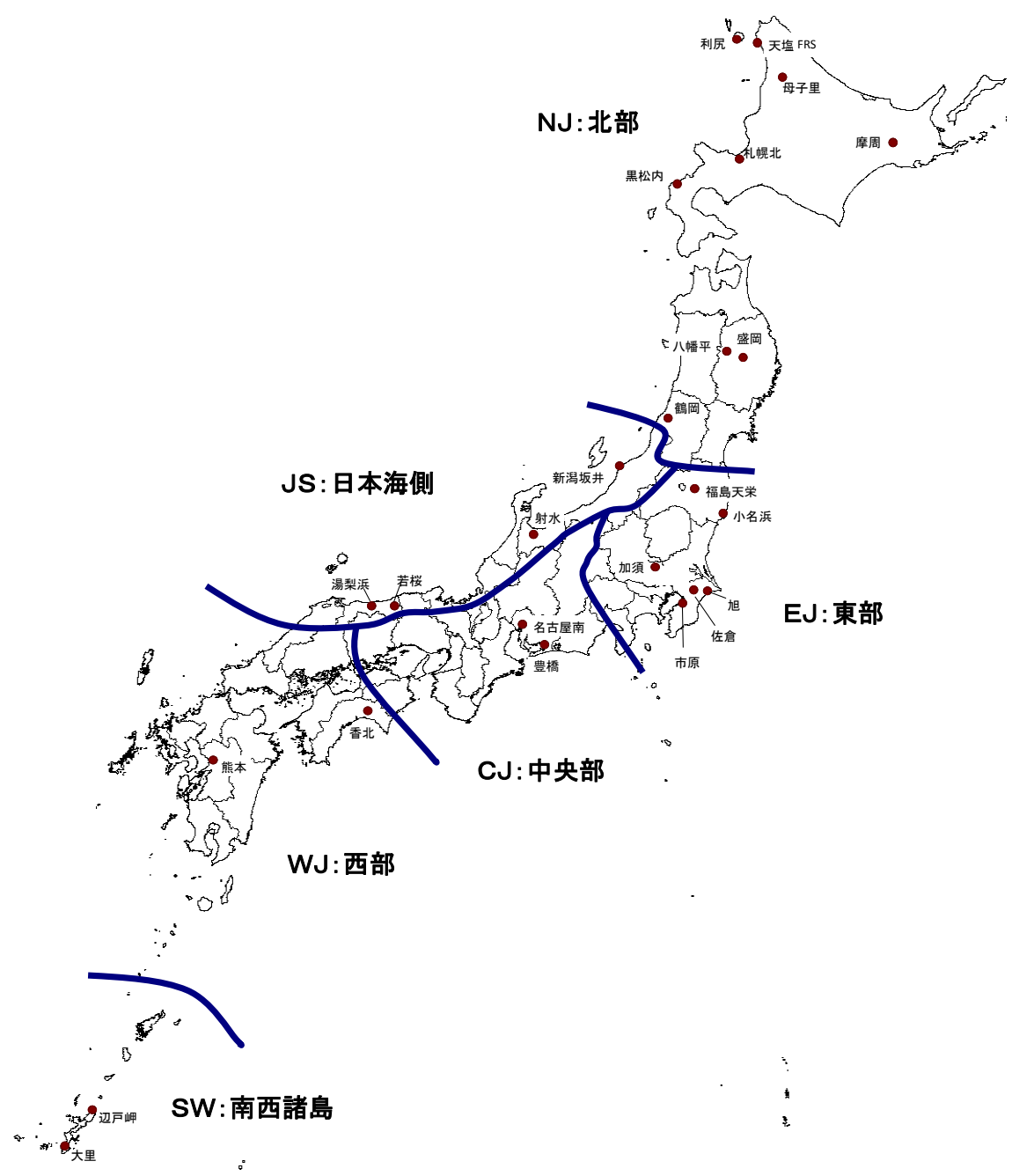

図6.1.1 パッシブサンプラー測定地点および地域区分 
表6.2.1 データ概況（2015年度）

\begin{tabular}{|c|c|c|c|c|c|c|c|c|c|c|c|c|c|}
\hline \multirow{2}{*}{ 項目 } & \multirow{2}{*}{ 地点数 } & \multicolumn{6}{|c|}{ 月別 } & \multicolumn{6}{|c|}{ 年間 } \\
\hline & & 欠測数 & データ数 & 適合数 & 有効割合 & 〈適合度 & <DL值* & 欠測数 & データ数 & 適合数 & 有効割合 & 〈適合度 & <DL值* \\
\hline $\mathrm{NO}_{2}$ & 16 & 1 & 192 & 186 & $97 \%$ & 5 & 3 & 0 & 16 & 16 & $100 \%$ & 0 & 0 \\
\hline NO & 16 & 5 & 163 & 153 & $94 \%$ & 5 & 22 & 0 & 16 & 16 & $100 \%$ & 0 & 0 \\
\hline $\mathrm{NO}_{\mathrm{x}}$ & 16 & 5 & 187 & 177 & $95 \%$ & 5 & 0 & 0 & 16 & 16 & $100 \%$ & 0 & 0 \\
\hline $\mathrm{O}_{3}$ & 15 & 0 & 180 & 175 & $97 \%$ & 5 & 0 & 0 & 15 & 15 & $100 \%$ & 0 & 0 \\
\hline $\mathrm{NH}_{3}$ & 25 & 2 & 300 & 293 & $98 \%$ & 5 & 12 & 0 & 25 & 25 & $100 \%$ & 0 & 0 \\
\hline
\end{tabular}

$(*:\langle\mathrm{DL}$ 值はNDの数を示す)

ている。調查は通年で行い, 試料捕集周期は1ヶ月 (4週間 または6週間) とした。2015年度は15機関25地点で害施さ れた。測定地点図を図6.1.1に示す。なお地点により測定 項目は異なる。また全国を地域区分した評価を行ってい るが，全地点で全項目を測ってはいないこと, 地点数が 少ない地域，土地利用の偏りがある地域もあることなど から, 必ずしも地域代表性に乏しい面があり, 解釈には 注意が必要である。 $\mathrm{NO}_{x}$ と $\mathrm{O}_{3}$ については, 都市部のパッシ ブサンプラーによる測定地点は少なくなっており, 測定 地点の多くは田園及び森林地域に位置する。このため, 地域平均濃度も都市部よりは田園や森林地域の濃度をよ り強く反映している。

またこれは電源を要しないパッシブサンプラーの特徴 を活かしているとも言える。

\section{2 測定結果}

$\mathrm{NO}_{\mathrm{x}}$ の年平均濃度と周辺排出量の相関を図6.2.1に, 地 域別季節変動を図6.2.2に示す。また 2015 年度データの欠 測数および期間適合度 $60 \%$ 以上の割合を表 6.2 .1 に示寸。 完全度の計算方法は, 月毎の完全度は「月毎の観測期間/ 月毎の予定された期間」，年の完全度は「年の観測期間/ 年の予定された期間」として計算している。全地点の年 平均濃度を表6.2.2 亿示す。

\section{6. $2.1 \mathrm{NO}_{2}$}

最高年平均濃度は札幌北 (11.8 ppb), 最低年平均濃度 は天塩FRS (0.3 ppb) と昨年度とほぼ同様である（表6.2. 2)。経月変化は全体的には例年と同様に, 冬季 (12〜2月) に高く, 夏季(6～9月)に低い傾向にある(図6.2.2)。NJ, $\mathrm{EJ}$, 冬季に濃度が高くなる傾向が都市部だけではなく黒 松内, 母子里など周辺排出量の少ない地域でも確認され る。これは暖房などの地域発生の寄与と思われる。また 八幡平でも冬季の濃度が高い傾向にあり, 盛岡など都市 域からの影響と考えられる。

\section{2. 2 NO}

最高年平均濃度は札幌北 $(6.6 \mathrm{ppb})$, 最低年平均濃度は 福島天栄 (0.1 ppb)だった(表6.2.2)。福島天栄では欠測 が3ケ月あるため, この值の取扱には注意が必要である。 その次に低濃度だったのは八幡平 $(0.3 \mathrm{ppb})$ で, これは例 年と同程度の濃度である。季節変化は $\mathrm{NO}_{2}$ と同様で冬季に 高い傾向にある。

\section{6. $2.3 \mathrm{NO}_{\mathrm{x}}$}

最高年平均濃度は札幌北 $(19.0 \mathrm{ppb})$, 最低年平均濃度 は天塩FRS (0.7 ppb)であり, 昨年度とほぼ同様の結果で ある (表6. 2.2)。地域別季節変動ではNO, $\mathrm{NO}_{2}$ 同様に冬季 に高く夏季に低い傾向にある(図6.2.2)。今回, EJの4-6 月の濃度が高いが，これは久測に伴い測定地点数が変化 したためである。それ以外の地域毎の傾向は概ね例年の とおりだが，NJ，JS，EJで1月に濃度が低くなっている。 何らかの広域の気象要因によるものかもしれない。

\section{6. $2.40_{3}$ およびPO}

$\mathrm{O}_{3}$ では最低年平均濃度は盛岡 $(23.7 \mathrm{ppb})$, 最高年平均 濃度は摩周 (44.3 ppb)で, 昨年とほぼ同様の結果だった (表6.2.2)。

全体的な濃度変動は例年どおり冬〜春季 $(2 \sim 5$ 月 $)$ に高く, 夏季まで減少を続け, 秋季 (9〜11月) 以降増加する傾向だ った(図6.2.2)。今年度はWJ, EJで10月にやや濃度が上昇 している。

P0 (ポテンシャルオゾン)濃度は次式により算出した。 $\mathrm{PO}=\mathrm{O}_{3}+\mathrm{NO}_{2}-0.1 \mathrm{NO}_{x}$

$\left(\mathrm{NO}_{2}\right.$ : 二酸化窒素濃度, $\mathrm{NO}_{\mathrm{x}}$ : 窒素酸化物濃度 $)$

都市部の地点が少ないため $\mathrm{NO}_{\mathrm{x}}$ の影響も小さく, $\mathrm{PO}$ は概 ね $\mathrm{O}_{3}$ と同じ傾向である。

\section{6. $2.5 \mathrm{NH}_{3}$}

例年どおり千葉県旭が突出して高く(105.1ppb)（表 6.1.2)，それを反映してEJの濃度が高くなっている。都 市部と一部田園地域で濃度が高い傾向にあり, 自動車排 ガス由来と農業由来の影響と考えられる。最低年平均濃 度は八幡平と香北 $(0.2 \mathrm{ppb})$ だった。千葉県を除いた地点 では年平均濃度は昨年同様に大里 $(9.4 \mathrm{ppb})$ が最も高い。 


\section{2.6 周辺排出量との関係}

$\mathrm{NO}_{\mathrm{x}}$ : 濃度と周辺排出量では (図6.2.1 (上)), 例年と同 様に概衩排出量の多い地域で濃度は高かった。大里は概 初同程度の排出量である新潟坂井や盛岡に比へ濃度が低 いが，これは周辺が海域であることなど立地や気象条件 が影響していると考えられる。

$\mathrm{NH}_{3}$ : 旭を除いた地点毎の年平均濃度と周辺排出量の関 係を図6.2.1 (下) に示す。大里を除くと概衫昨年度と同様 に，周辺排出量と関係が認められる。

\subsection{7 フィルターパック法(FP法)によるアンモニ ア濃度との比較}

PS法とFP法による $\mathrm{NH}_{3}$ 濃度測定結果を比較すると, 年平 均值では概ね一致した(表6.2.2)。しかし, 月平均值では 濃度の大きく異なる地点が見られた ${ }^{3)}$ 。

この要因として, 気温の高い時期にFP法はアーティフ アクトにより $\mathrm{NH}_{3}$ 濃度を過大評価し, 逆に気温の低い時期 はPS法がアンモニウム粒子の付着等により過大評価する ためではと推測される。

しかし, 濃度が数倍異なる場合には, サンプルの取り 扱い上の誤差等も含まれると思われる。今年度からはじ まった第6次調查では, こうした両方法による誤差要因を 明らかにする一方，分析ミス等の管理にもより注意を払 っていく必要があると思われる。

\subsection{8 継続地点の年平均濃度変化}

2003年度から2015年度までの地域ごとの濃度変動をま とめた(図6.2.3)。小川式パッシブサンプラーが当初北海 道東北地域を中心に導入されたため, 大半の地点がこの 地域内となる。

（1） $\mathrm{NO}_{\mathrm{x}}$ は濃度減少傾向がみられ，都市部など濃度の高 い地点のみならず，低濃度の地点でも同様であった。 自動車のハイブリット化などが一因と考えられる。

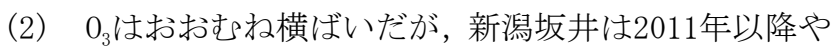
や濃度が増加し, 逆に八幡平ではやや減少傾向にある。 2015年に八幡平，盛岡などで大幅に減少しているが， これは今後検討が必要である。都市部は少なく, 窒素 酸化物の影響が小さいためPOはほぼ $0_{3}$ 同様の結果とな る。

越境污染の影響については, その度合いが季節によ り異なるため, 季節別の検討が必要だろう。長期的な $0_{3}$ 濃度の増減についてはより観測が必要である。

(3) $\mathrm{NH}_{3}$ は全体的に減少傾向がみられる。測定地点近傍 の影響が大きいため, 主要な排出源である畜産業など の変動が影響している可能性がある。

第5次調査までは地域毎に評価を行ってきたが, 地点の 増減により傾向が変わること, 地点数の少ない地域では 地域代表性は少ないなど課題があるため, 今後は地点毎 の評価を検討する。
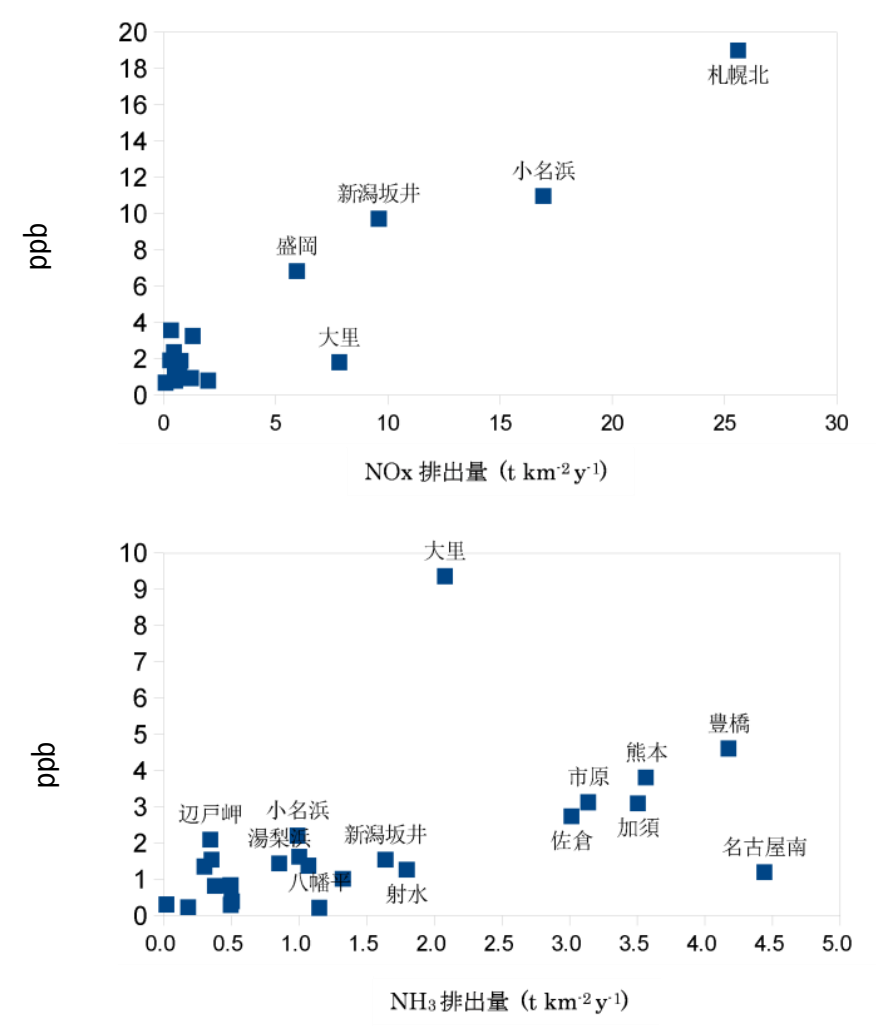

図6.2.1 年平均 $\mathrm{NO}_{\mathrm{x}}$ 濃度 (上)および年平均 $\mathrm{NH}_{3}$ 濃度 (下) (旭は除く) 


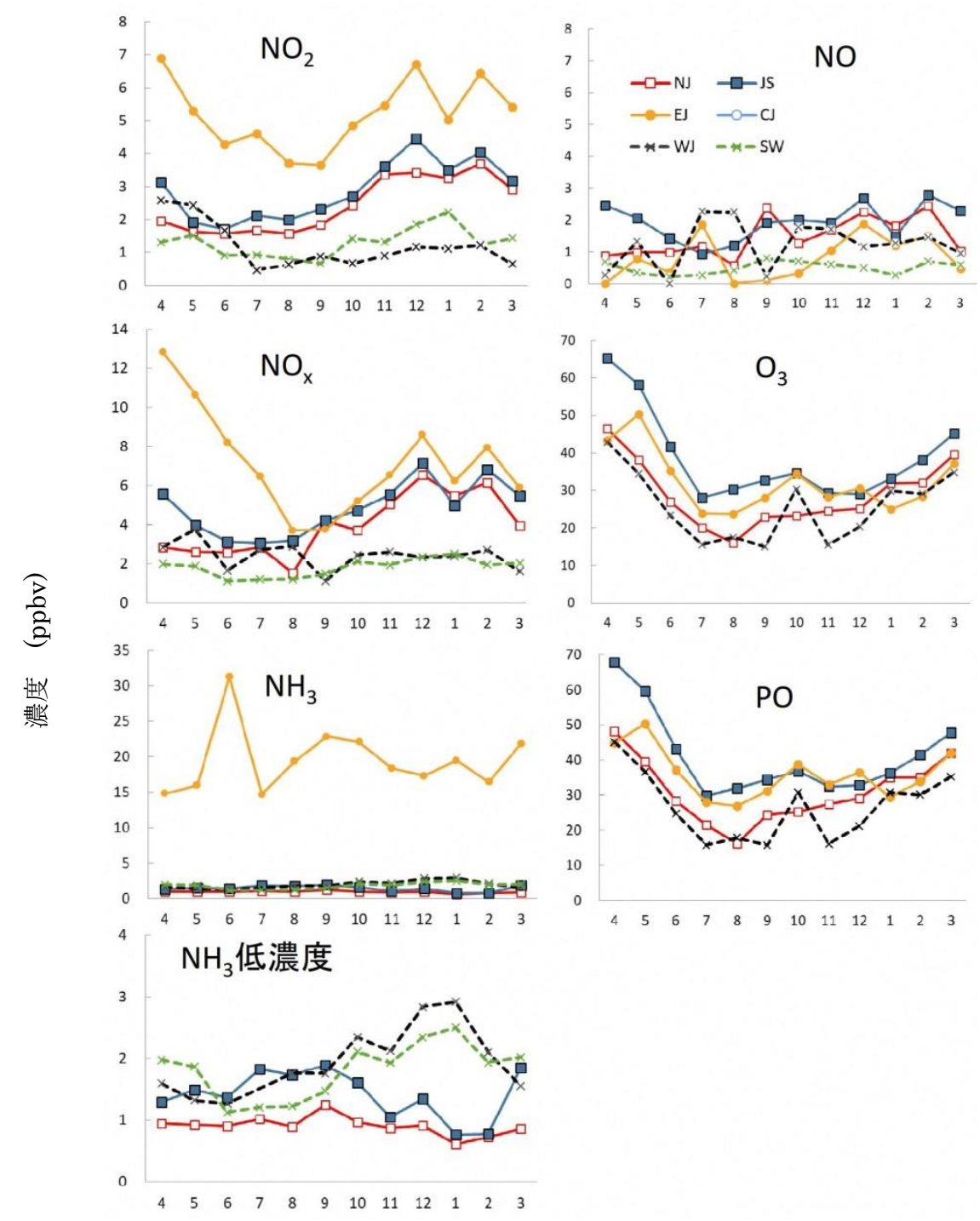

図6.2.2 地域別季節変動 
表6.2.2 ガス状物質の地点別年平均濃度 (ppb)

\begin{tabular}{|c|c|c|c|c|c|c|c|c|c|}
\hline 地域区分 & 自治体 & 地点 & $\mathrm{NO}_{2}$ & NO & $\mathrm{NO}_{x}$ & $\mathrm{O}_{3}$ & $\mathrm{PO}$ & $\mathrm{NH}_{3}$ & $\begin{array}{l}\mathrm{FPI} よ る \\
\mathrm{NH}_{3}(\mathrm{ppb})\end{array}$ \\
\hline $\mathrm{NJ}$ & 北海道 & 利尻 & 0.4 & 0.4 & 0.8 & 37.2 & 37.6 & 0.3 & 0.4 \\
\hline $\mathrm{NJ}$ & 北海道 & 天塩FRS & 0.3 & 0.4 & 0.7 & 29.0 & 29.2 & 0.3 & \\
\hline $\mathrm{NJ}$ & 北海道 & 母子里 & 1.1 & 0.8 & 1.9 & 28.5 & 29.4 & 0.8 & \\
\hline $\mathrm{NJ}$ & 北海道 & 黒松内 & 2.0 & 1.6 & 3.6 & 25.3 & 27.0 & & \\
\hline $\mathrm{NJ}$ & 北海道 & 札幌北 & 11.8 & 6.6 & 19.0 & 24.8 & 34.7 & 1.4 & 1.6 \\
\hline $\mathrm{NJ}$ & 北海道 & 摩周 & 0.3 & 1.6 & 1.9 & 44.3 & 44.3 & & \\
\hline $\mathrm{NJ}$ & 岩手県 & 盛岡 & 5.3 & 1.0 & 6.8 & 19.0 & 23.7 & 1.0 & \\
\hline $\mathrm{NJ}$ & 岩手県 & 八幡平 & 0.5 & 0.3 & 0.8 & 24.6 & 25.1 & 0.2 & \\
\hline $\mathrm{NJ}$ & 山形県 & 鶴岡 & 0.7 & 1.0 & 1.7 & 25.8 & 26.3 & 0.8 & \\
\hline EJ & 福島県 & 福島天栄 & 0.8 & 0.1 & 0.9 & 41.3 & 42.0 & 0.4 & \\
\hline EJ & いわき市 & 小名浜 & 9.6 & 1.4 & 11.0 & 22.4 & 30.9 & 2.2 & \\
\hline JS & 新潟市 & 新潟坂井 & 7.3 & 2.4 & 9.7 & 35.6 & 41.9 & 1.6 & \\
\hline EJ & 埼玉県 & 加須 & & & & & & 3.1 & 5.0 \\
\hline EJ & 千葉県 & 市原 & & & & & & 3.1 & 3.2 \\
\hline EJ & 千葉県 & 旭 & & & & & & 105.1 & 86.7 \\
\hline EJ & 千葉県 & 佐倉 & & & & & & 2.7 & 3.0 \\
\hline JS & 富山県 & 射水 & & & & & & 1.3 & \\
\hline CJ & 愛知県 & 豊橋 & & & & & & 4.6 & 3.9 \\
\hline CJ & 名古屋市 & 名古屋南 & & & & & & 1.2 & 3.2 \\
\hline JS & 鳥取県 & 若桜 & 0.5 & 1.6 & 2.1 & 43.7 & 44.0 & 0.9 & \\
\hline JS & 鳥取県 & 湯梨浜 & 1.5 & 2.2 & 3.7 & 36.3 & 37.4 & 1.5 & 1.4 \\
\hline WJ & 高知県 & 香北 & 1.2 & 1.2 & 2.4 & 25.5 & 26.4 & 0.2 & 0.4 \\
\hline WJ & 熊本市 & 熊本 & & & & & & 3.8 & \\
\hline SW & 沖縄県 & 辺戸岬 & & & & & & 2.1 & 1.1 \\
\hline SW & 沖縄県 & 大里 & 1.3 & 0.5 & 1.8 & & & 9.4 & 7.8 \\
\hline
\end{tabular}

*全国最低値は網掛け, 全国最高值は白抜きで示した。 


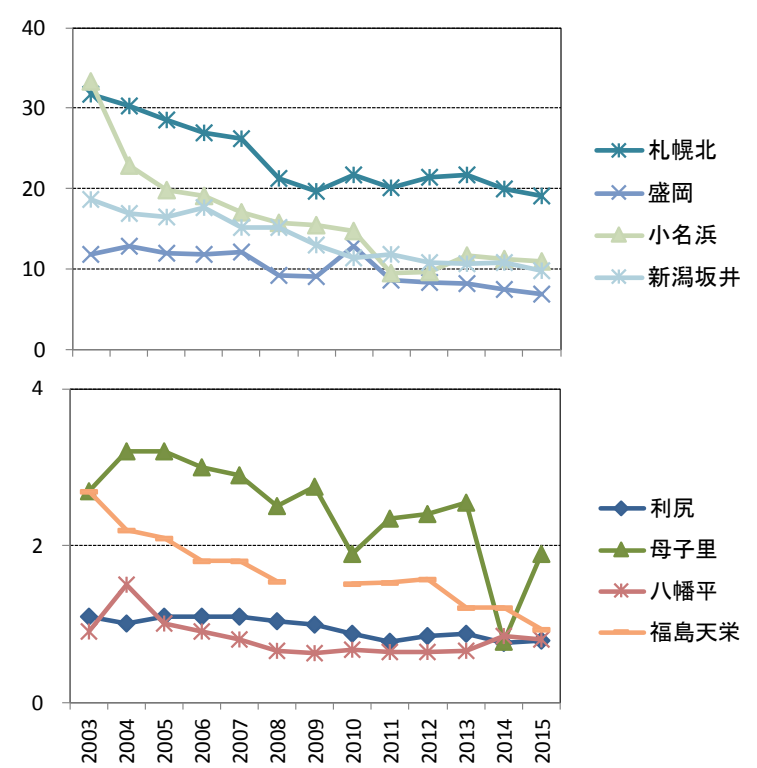

（1） $\mathrm{N}_{\mathrm{x}}$ 高濃度地点（上）と低濃度地点（下）

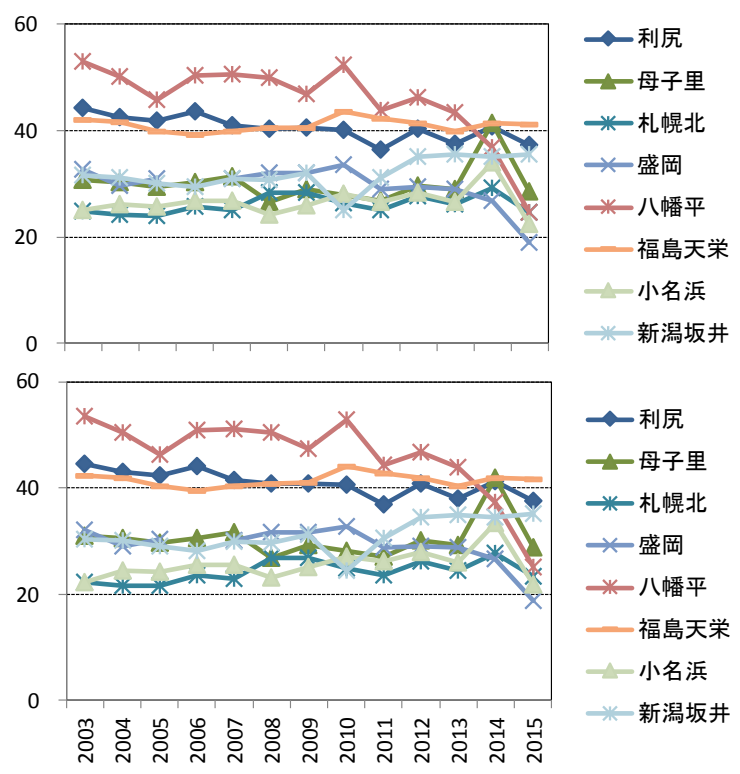

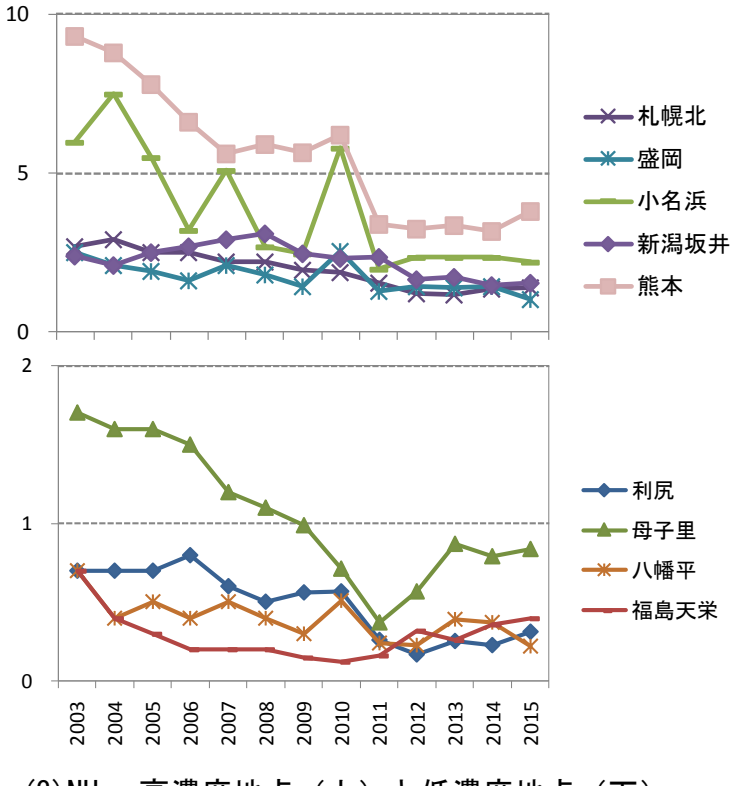

(3) $\mathrm{NH}_{3}$ 高濃度地点（上） と低濃度地点（下）

図6.2.3継続地点の経年変化 $(\mathrm{ppb})$

\section{一 引用文 献 -}

1）野口泉：ガス状および粒子状アンモニアの捕集測定 方法 (拡散デニューダ法, フィルターパック法およびパ ッシブ法), 第48回大気環境学会講演要旨集, 244-245, 2007
2）全国環境研協議会 酸性雨広域大気污染調查研究部 会，全国環境研会誌，34(3)，193-223，2009

3) 山口高志他: 全国酸性雨調査 (81) 乾性沈着 (パッシブ 法によるアンモニア濃度測定結果), 第54回大気環境学 会講演要旨集，266，2013 


\section{7. まとめ}

2015年度および第5次酸性雨全国調査の結果概要は以 下の通りである。

\section{1 湿性沈着}

JSおよびWJでは，冬季および春季に $\mathrm{nss}^{-} \mathrm{SO}_{4}{ }^{2-} お よ ひ ゙ H^{+}$ 濃度が高い傾向を示しており，この傾向は，2005年度ま ではJSで顕著であったが，2006年度にはWJでも冬季に高 濃度となる傾向が確認され，2014年度まで引き続き同様 の傾向にあった。 $\mathrm{nss}^{-} \mathrm{SO}_{4}{ }^{2-} お よ ひ ゙ H^{+}$沈着量はWJ, 次いで JSで多い傾向を示した。季節変動は ${ }^{+}, \mathrm{NO}_{3}$-および $\mathrm{nSS}^{-} \mathrm{SO}_{4}{ }^{2-}$ 沈着量についてJSで冬季に多い傾向が顕著であ り，WJでは4月および6〜8月に多い傾向があった。

第5次調查の経年変動について, イオン成分濃度では, 地域区分別には $\mathrm{nsS}^{-} \mathrm{SO}_{4}{ }^{2-} お よ ひ ゙ \mathrm{NO}_{3}{ }^{-}$濃度でJSが一貫して 高濃度であった。また, nss-Ca ${ }^{2+}$ 濃度は低下傾向にあった が, その他の主要イオン成分濃度はほぼ横ばいの傾向が あった。沈着量では, 地域区分別には主要イオン成分沈 着量でJSがほぼ一貫して多く, 次いでWJで多かった。ま た, $\mathrm{nss}^{-} \mathrm{Ca}^{2+}$ 沈着量は減少傾向にあったが, その他の主要 イオン成分沈着量はほぼ横ばいもしくは微減傾向を示し た。このうちJSでは2013年度をピークに減少の傾向がみ られ，年平均濃度および降水量の減少に起因していると 考えられた。

\section{2 乾性沈着（フィルターパック法）}

全国31地点でFP法による乾性沈着調查を実施したとこ ろ，2015年度の大気中のガス状および粒子状成分の年平 均値は, 昨年度と同程度であった。 $\mathrm{SO}_{2}(\mathrm{~g})$ 濃度はWJで, $\mathrm{HNO}_{3}(\mathrm{~g})$ 濃度はCJで, $\mathrm{NH}_{3}(\mathrm{~g})$ 濃度は畜産業の影響を受けて いると考えられる地点や都市部で高かった。粒子状成分
の総当量濃度はSWで最も高く, NJおよびSWを除く地域で は，陰イオンはSO ${ }_{4}^{2-}$, 陽イオンは $\mathrm{NH}_{4}^{+}$の占める割合が高か った。NJおよびSWでは $\mathrm{Na}^{+} と \mathrm{Cl}^{-}$の占める割合が高く， EJ ではNO $\mathrm{N}_{3}^{-}$の割合が高かった。

第4次および第5次調查で得られた年度別全国中央值の 経年変化をみると, $\mathrm{HNO}_{3}(\mathrm{~g})$ およびNH $\mathrm{N}_{3}(\mathrm{~g})$ 濃度は2003年度 から2015年度にかけて減少傾向を示した。 $\mathrm{SO}_{2}(\mathrm{~g})$ 濃度は 2003年度以降に減少しているが，2011～2013年度に一旦 増加し，2014〜2015年度に再び減少した。 $\mathrm{nss}^{-} \mathrm{SO}_{4}{ }^{2-}$ (p) 濃度は，2005年度をピークに減少し，2013年度から2014 年度にかけて一旦増加したが, その後再び減少した。 $\mathrm{nss}^{-} \mathrm{Ca}^{2+}(\mathrm{p})$ 濃度は微増傾向がみられた。日本の $\mathrm{nss}^{-} \mathrm{SO}_{4}{ }^{2-}(\mathrm{p})$ およびnss-Ca ${ }^{2+}(\mathrm{p})$ 濃度の経年変化はアジア 大陸を起源とする $\mathrm{SO}_{2}$ や黄砂の影響を強く受けていると 考えられる。

\section{3 乾性沈着量}

FP法の測定結果から, 乾性沈着推計ファイルを用いて インファレンシャル法による乾性沈着量の推計を行った。 ガス状物質と粒子状物質を合わせた乾性沈着量の全国平 均值は, 非海塩由来硫黄成分 $10.4 \mathrm{mmolm}^{-2} \mathrm{y}^{-1}, \mathrm{NO}_{\mathrm{x}}$ を含ま ない酸化態窒素成分が $15.9 \mathrm{mmolm}^{-2} \mathrm{y}^{-1}$, 還元態窒素成分 が36. $2 \mathrm{mmolm}^{-2} \mathrm{y}^{-}$だった。

\section{4 ガス成分濃度 (パッシブ法)}

今年度のパッシブ法による $\mathrm{NO}_{2}, \mathrm{NO}, \mathrm{O}_{3}$, および $\mathrm{NH}_{3}$ の測 定結果は概衫例年通りで， $0_{3}$ は山岳部や海岸部の地点は 内陸部より高く, $\mathrm{NH}_{3}$ は都市部と酪農業の盛んな地域で高 い傾向にあった。2003年から継続している測定地点の長 期傾向を検討すると, $\mathrm{NO}_{\mathrm{x}}$ と $\mathrm{NH}_{3}$ は減少傾向にあった。一方 $0_{3}$ は概ね横ばいだった。 